Prepared as part of the Glacial Aquifer System Groundwater Availability Study, a cooperative effort between the U.S. Department of the Interior's WaterSMART Initiative and the U.S. Geological Survey's Water Availability and Use Science Program

\title{
Simulation of Potential Groundwater Recharge for the Glacial Aquifer System East of the Rocky Mountains, 1980-2011, using the Soil-Water-Balance Model
}

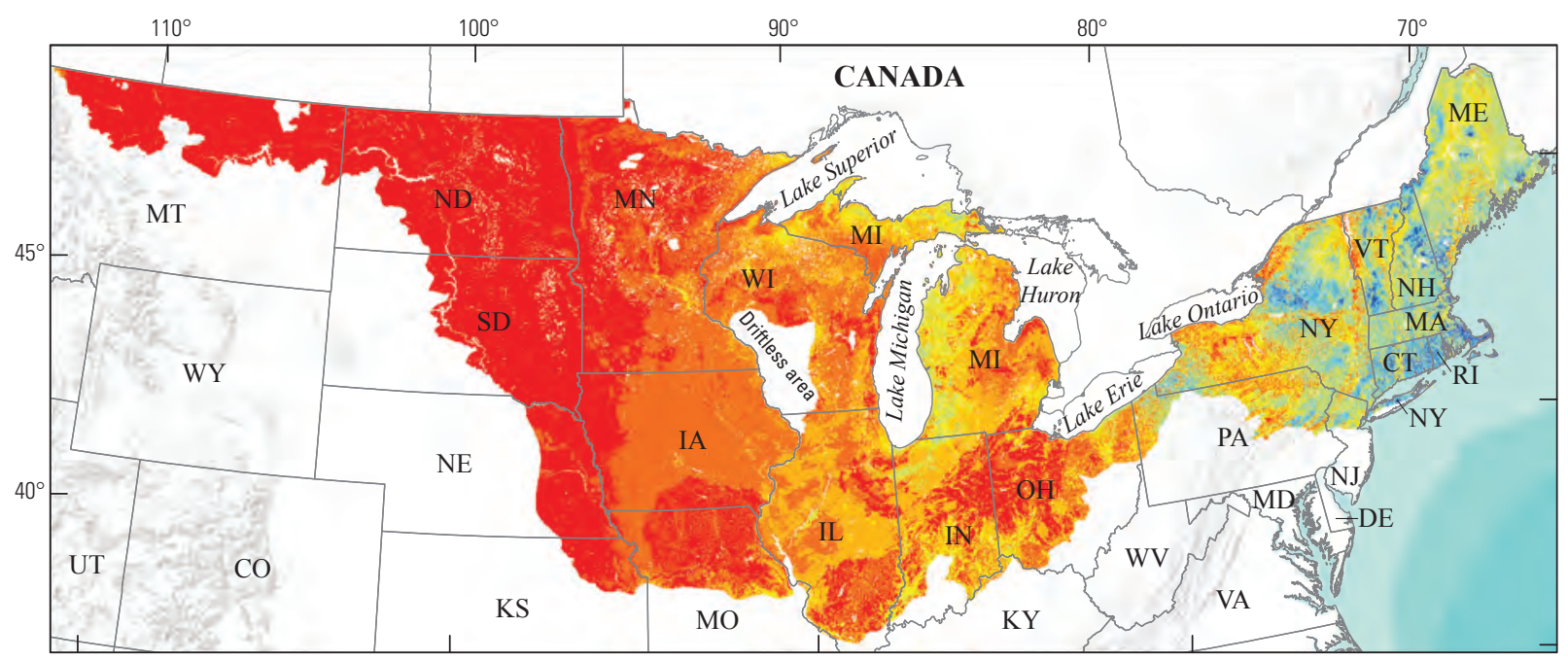

Scientific Investigations Report 2018-5080 
Cover. Map showing mean annual potential recharge rates from 1980 to 2011 simulated with the glacial Soil-Water-Balance model modified from figure 14 of the report. 


\section{Simulation of Potential Groundwater Recharge for the Glacial Aquifer System East of the Rocky Mountains, 1980-2011, using the Soil-Water-Balance Model}

By Jared J. Trost, Jason L. Roth, Stephen M. Westenbroek, and Howard W. Reeves

Prepared as part of the Glacial Aquifer System Groundwater Availability Study, a cooperative effort between the U.S. Department of the Interior's WaterSMART Initiative and the U.S. Geological Survey's Water Availability and Use Science Program

Scientific Investigations Report 2018-5080 


\title{
U.S. Department of the Interior \\ RYAN K. ZINKE, Secretary
}

\author{
U.S. Geological Survey \\ James F. Reilly II, Director
}

U.S. Geological Survey, Reston, Virginia: 2018

For more information on the USGS - the Federal source for science about the Earth, its natural and living resources, natural hazards, and the environment-visit https://www.usgs.gov or call 1-888-ASK-USGS.

For an overview of USGS information products, including maps, imagery, and publications,

visit https://store.usgs.gov.

Any use of trade, firm, or product names is for descriptive purposes only and does not imply endorsement by the U.S. Government.

Although this information product, for the most part, is in the public domain, it also may contain copyrighted materials as noted in the text. Permission to reproduce copyrighted items must be secured from the copyright owner.

Suggested citation:

Trost, J.J., Roth, J.L., Westenbroek, S.M., and Reeves, H.W., 2018, Simulation of potential groundwater recharge for the glacial aquifer system east of the Rocky Mountains, 1980-2011, using the Soil-Water-Balance model: U.S. Geological Survey Scientific Investigations Report 2018-5080, 51 p., https://doi.org/10.3133/sir20185080.

ISSN 3828-0328 (online) 


\section{Contents}

Abstract

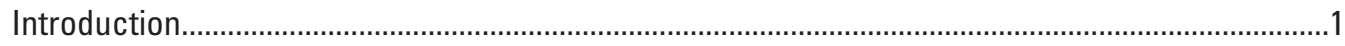

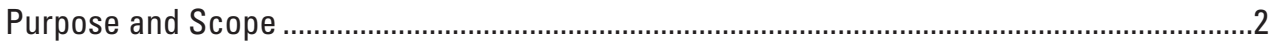

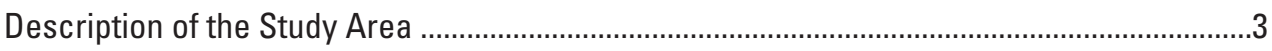

Definition of Potential Groundwater Recharge for this Report.................................................3

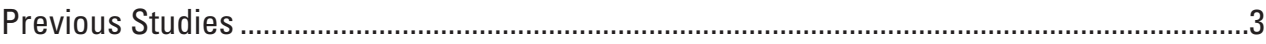

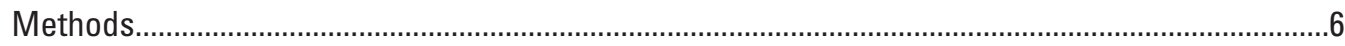

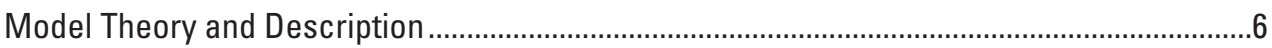

Model Limitations and Assumptions .......................................................................................

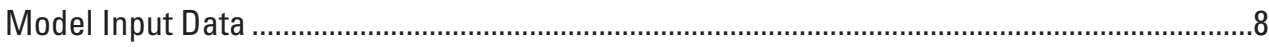

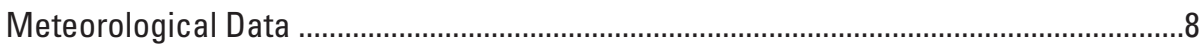

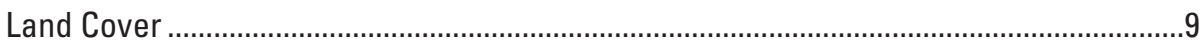

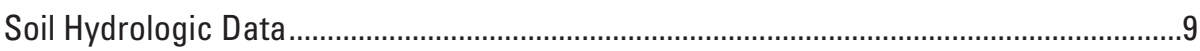

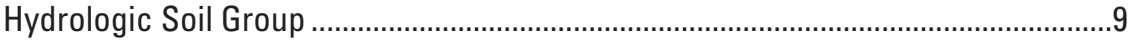

Available Water Capacity ......................................................................................12

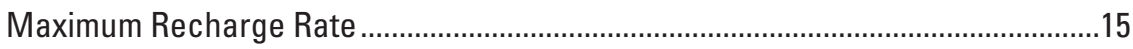

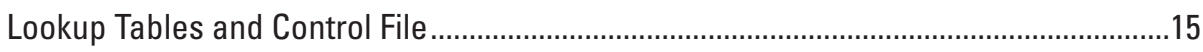

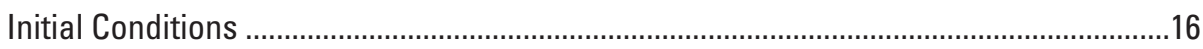

Model Calibration and Evaluation Methods ………..........................................................16

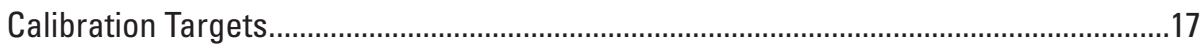

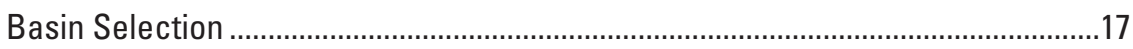

Base-Flow (Recharge) Observations and Weights...............................................17

Parameter Estimation .................................................................................................

Statistical Methods for Evaluating Model Fit and Model Error.........................................21

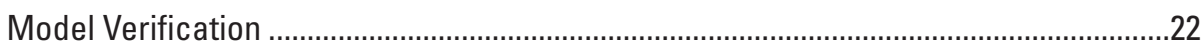

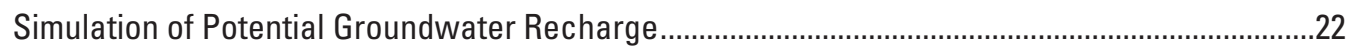

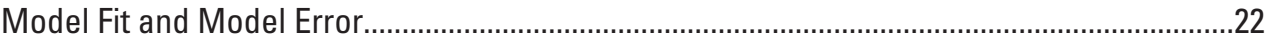

1980-2011 Potential Recharge to the Glacial Aquifer System ..............................................27

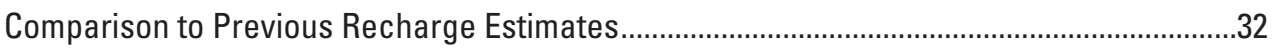

Sensitivity Analysis ............................................................................................................. 41

Glacial Soil-Water-Balance Model................................................................................ 41

Comparison of Parameter Sensitivities................................................................................

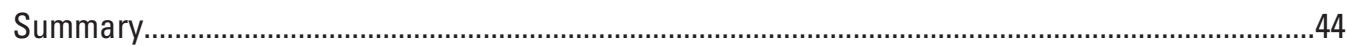

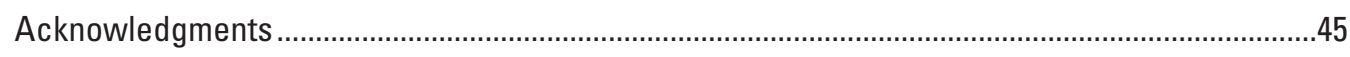

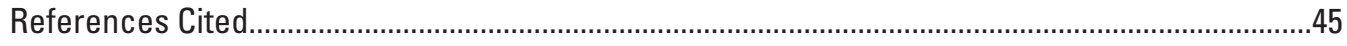

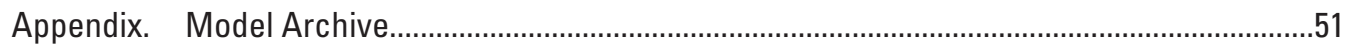




\section{Figures}

1. Map showing extent of the glacial aquifer system included in the domain of the glacial Soil-Water-Balance model and the basins used for model calibration .................2

2. Conceptual diagram of the Soil-Water-Balance model.

3. Map showing mean annual gross precipitation within the extent of the glacial aquifer system at a 1-kilometer resolution for 1980-2011, summarized from the Daymet dataset

4. Map showing land-cover classes according to the 2006 National Land Cover Database within the extent of the glacial aquifer system at a 1-kilometer resolution ...11

5. Map showing hydrologic soil groups within the extent of the glacial aquifer system at a 1-kilometer resolution, based on the Digital General Soil Map of the United States

6. Map showing available soil-water capacity within the extent of the glacial aquifer system at a 1-kilometer resolution, based on the Digital General Soil Map of the United States

7. Graph showing example stream hydrograph and base flow from three hydrograph separation techniques, HYSEP local minimum, PART, and base-flow index for U.S. Geological Survey streamgage 01552000, Loyalsock Creek at Loyalsockville, Pennsylvania

8. Map showing the 38 basins used to verify the glacial Soil-Water-Balance model.........23

9. Graphs showing relations between HYSEP local minimum base flow and potential recharge simulated with the glacial Soil-Water-Balance model for 39 calibration basins during $1980-2011$....

10. Histogram of residuals during 1980-2011

11. Map showing residuals in mean annual potential recharge between the glacial Soil-Water-Balance model and base flow determined with the HYSEP local minimum method for the 39 calibration basins during 1980-2011

12. Graph showing mean annual potential recharge from the glacial Soil-WaterBalance model, mean annual HYSEP local minimum base flow, and range of mean annual base flow from five hydrograph separation techniques, PART, HYSEP local minimum, HYSEP fixed-interval, HYSEP sliding, and base-flow index during 1980-2011

13. Graphs showing mean annual HYSEP local minimum base flow and mean annual potential recharge simulated with the glacial Soil-Water-Balance model for 38 verification basins

14. Map showing mean annual potential recharge from 1980 to 2011 simulated with the glacial Soil-Water-Balance model

15. Histogram of mean annual potential recharge from the glacial

Soil-Water-Balance model during 1980 to 2011 for the glacial aquifer system

16. Maps showing results from the glacial Soil-Water-Balance model.

17. Graphs showing percent of 1980-2011 potential recharge to the glacial aquifer system...

18. Map showing mean annual potential recharge as a percent of mean annual gross precipitation based on results from the glacial Soil-Water-Balance model

19. Graph showing annual potential recharge from 1980 to 2011 simulated with the glacial Soil-Water-Balance model within three regions of the glacial aquifer system extent

20. Map showing boundaries of the glacial Soil-Water-Balance model and boundaries of previously published recharge models. 
21. Boxplot showing cell-by-cell differences between mean annual potential recharge from the glacial Soil-Water-Balance model and four previously

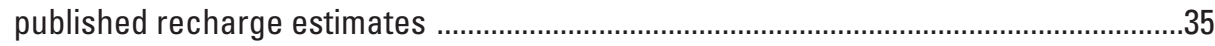

22. Maps showing the glacial aquifer system................................................................36

23. Map showing the difference between the 1951-80 mean annual recharge determined by Wolock and the 1980-2011 mean annual potential recharge simulated with the glacial Soil-Water-Balance model......

24. Maps showing 1981-2011 mean annual potential recharge in the coincident model domains

25. Maps showing 1996-2010 mean annual potential recharge in the coincident model domains.

26. Maps showing 1980-2011 mean annual potential recharge in the coincident model domains

\section{Tables}

1. Percentage of the glacial aquifer system by 2001 land-cover class from the National Land Cover Database dataset and the Digital General Soil Map of the United States hydrologic soil group

2. Percentage of the glacial aquifer system by 2006 land-cover class from the National Land Cover Database dataset and the Digital General Soil Map of the United States hydrologic soil group

3. Percentage of the glacial aquifer system by 2011 land-cover class from the National Land Cover Database dataset and the Digital General Soil Map of the United States hydrologic soil group

4. Lookup table for the calibrated Soil-Water-Balance model, corresponding land cover to runoff curve number, maximum recharge rate, interception storage, and root-zone depth

5. Selected characteristics, simulated potential recharge from the glacial Soil-Water-Balance (SWB) model, recharge determined using five hydrograph separation techniques, residual statistics, and calibration weights for 77 basins used for the glacial SWB model calibration and verification available at https://doi.org/10.3133/sir20185080

6. Distribution of land cover in the calibration basins and for the glacial Soil-Water-Balance model domain, based on the 2006 National Land Cover Database

7. Distribution of hydrologic soil groups in the calibration basins and for the glacial Soil-Water-Balance model domain, based on the STATSG02 soil database.....

8. Calibration parameter descriptions, values, and bounds for the glacial Soil-Water-Balance model available at https://doi.org/10.3133/sir20185080

9. Model evaluation statistics between recharge determined with the HYSEP local minimum technique and corresponding potential recharge estimates from the glacial Soil-Water-Balance model for the 39 calibration basins and 38 verification basins

10. Mean annual potential recharge rates simulated by the glacial Soil-Water-Balance model, by land-cover class and hydrologic soil group, for the period 1980-2011

11. Sensitivity of model error to changes in parameters of the calibrated glacial Soil-Water-Balance model. 


\section{Conversion Factors}

U.S. customary units to International System of Units

\begin{tabular}{|c|c|c|}
\hline Multiply & By & To obtain \\
\hline \multicolumn{3}{|c|}{ Length } \\
\hline inch (in.) & 2.54 & centimeter $(\mathrm{cm})$ \\
\hline inch (in.) & 25.4 & millimeter $(\mathrm{mm})$ \\
\hline foot (ft) & 0.3048 & meter $(\mathrm{m})$ \\
\hline mile (mi) & 1.609 & kilometer $(\mathrm{km})$ \\
\hline yard (yd) & 0.9144 & meter $(\mathrm{m})$ \\
\hline \multicolumn{3}{|c|}{ Area } \\
\hline square mile $\left(\mathrm{mi}^{2}\right)$ & 2.590 & square kilometer $\left(\mathrm{km}^{2}\right)$ \\
\hline \multicolumn{3}{|c|}{ Flow rate } \\
\hline cubic foot per second $\left(\mathrm{ft}^{3} / \mathrm{s}\right)$ & 0.02832 & cubic meter per second $\left(\mathrm{m}^{3} / \mathrm{s}\right)$ \\
\hline inch per year (in/yr) & 25.4 & millimeter per year (mm/yr) \\
\hline
\end{tabular}

Temperature in degrees Celsius $\left({ }^{\circ} \mathrm{C}\right)$ may be converted to degrees Fahrenheit $\left({ }^{\circ} \mathrm{F}\right)$ as follows:

$$
{ }^{\circ} \mathrm{F}=\left(1.8 \times{ }^{\circ} \mathrm{C}\right)+32 .
$$

Temperature in degrees Fahrenheit $\left({ }^{\circ} \mathrm{F}\right)$ may be converted to degrees Celsius $\left({ }^{\circ} \mathrm{C}\right)$ as follows:

$$
{ }^{\circ} \mathrm{C}=\left({ }^{\circ} \mathrm{F}-32\right) / 1.8 \text {. }
$$

\section{Datum}

Vertical coordinate information is referenced to the North American Vertical Datum of 1988 (NAVD 88).

Horizontal coordinate information is referenced to the North American Datum of 1983 (NAD 83). Altitude, as used in this report, refers to distance above the vertical datum. 


\section{Abbreviations}

$\begin{array}{ll}> & \text { greater than } \\ \text { AME } & \text { absolute mean error } \\ \text { ASCII } & \text { American Standard Code for Information Interchange } \\ \text { AWC } & \text { available water capacity } \\ \text { BFI } & \text { base-flow index } \\ \text { CFGI } & \text { continuous frozen ground index } \\ \text { ET } & \text { evapotranspiration } \\ \text { GAGES II } & \text { Geospatial Attributes of Gages for Evaluating Streamflow, version II } \\ \text { HSG } & \text { hydrologic soil group } \\ \text { HUC } & \text { hydrologic unit code } \\ \text { NLCD } & \text { National Land Cover Database } \\ \text { NSE } & \text { Nash-Sutcliffe model efficiency coefficient } \\ \text { PPCC } & \text { probability plot correlation coefficient } \\ \text { RMSE } & \text { root mean squared error } \\ \text { RSR } & \text { root mean squared error to standard deviation of the observations ratio } \\ \text { SC } & \text { snow cover } \\ \text { SSURGO } & \text { Soil Survey Geographic [database] } \\ \text { STATSG02 } & \text { State Soil Geographic [database] } \\ \text { SWB } & \text { Soil-Water-Balance } \\ \text { SWC } & \text { soil-water content } \\ \text { USGS } & \text { U.S. Geological Survey }\end{array}$





\title{
Simulation of Potential Groundwater Recharge for the Glacial Aquifer System East of the Rocky Mountains, 1980-2011, using the Soil-Water-Balance Model
}

\author{
By Jared J. Trost, Jason L. Roth, Stephen M. Westenbroek, and Howard W. Reeves
}

\section{Abstract}

An understanding of the spatial and temporal extent of groundwater recharge is critical for many types of hydrologic assessments involving water quality, contaminant transport, ecosystem health, and sustainable use of groundwater. Annual potential groundwater recharge was simulated at a 1-kilometer resolution with the Soil-Water-Balance (SWB) model for the glacial aquifer system east of the Rocky Mountains, from central Montana east to Maine, for calendar years 1980-2011. The SWB model used high resolution meteorological, land cover, and soil hydrology datasets that are nationally consistent and publicly available. The SWB model computed daily potential groundwater recharge as precipitation in excess of interception, runoff, evapotranspiration, and soil-water storage capacity. Daily potential recharge values within each year of the simulation were summed to produce annual potential recharge rates. Potential recharge as described in this report is water that infiltrates vertically below the plant rooting zone and is assumed to reach the water table.

The calibrated SWB model in this report is called the glacial SWB model. Model calibration assumed that the area contributing to groundwater discharge equaled the surface watershed. The model was calibrated to stream base flows from 39 watersheds throughout the model domain that had hydrologic conditions appropriate for hydrograph separation. Base flows were calculated from daily streamflow records with the HYSEP local minimum hydrograph separation method The glacial SWB model reproduced the mean annual baseflow calibration targets well; the Nash-Sutcliffe efficiency coefficient was 0.94 , and the root mean squared error was 1.28 inches per year.

The glacial SWB model provides insight into the spatial and temporal variability in potential annual recharge across the glacial aquifer system. About 20 percent of the active model area had an average potential recharge rate of less than 1 inch per year. Total precipitation, total recharge, and recharge as a percentage of precipitation increased from west to east. A substantial amount of the recharge water (39 percent) entering the glacial aquifer system travels through developed (urbanized) and agricultural landscapes, which are known to cause waterquality impairments. Regional climatic events, such as the 1988 to 1989 drought, are apparent in the potential recharge time series. Potential recharge generally increased across the glacial aquifer system between 2001 and 2011.

A comparison of the potential recharge from the glacial SWB model to previous broad-scale recharge estimates reveals several important considerations for future SWB modeling applications. Shifts in the overall distribution of potential recharge between separate models can be explained by methods used to generate base-flow calibration target datasets. Spatial patterns in potential recharge simulated by SWB models are strongly dependent on the data and assumptions used to assign model cells to hydrologic soil groups. A review of several SWB models used to estimate groundwater recharge (and not surface runoff) revealed that model results are most sensitive to input climatic data, followed by surface runoff (curve number) and root-zone depth parameters.

\section{Introduction}

The glacial aquifer system is an important source of water for millions of people and supports numerous natural ecosystems across 26 States in the northern United States (Warner and Arnold, 2006). The glacial aquifer system includes all unconsolidated aquifers above bedrock within the glaciated area of the United States (fig. 1). It is the "principal aquifer" for most of the northern United States. A principal aquifer is a regionally extensive aquifer system from which potable water supplies are being or could be extracted (Warner and Arnold, 2006). Approximately 41 million people relied on the glacial aquifer system for public and private water supply in 2000 (Warner and Arnold, 2006). The glacial aquifer system is subject to a range of climatic conditions: humid to semiarid, maritime to continental to arctic (Reeves and others, 2017). Groundwater availability in the system may be controlled by climatic conditions that affect water inputs and losses in addition to hydrogeological constraints of storage capacity and low hydraulic conductivity. Other considerations related to 


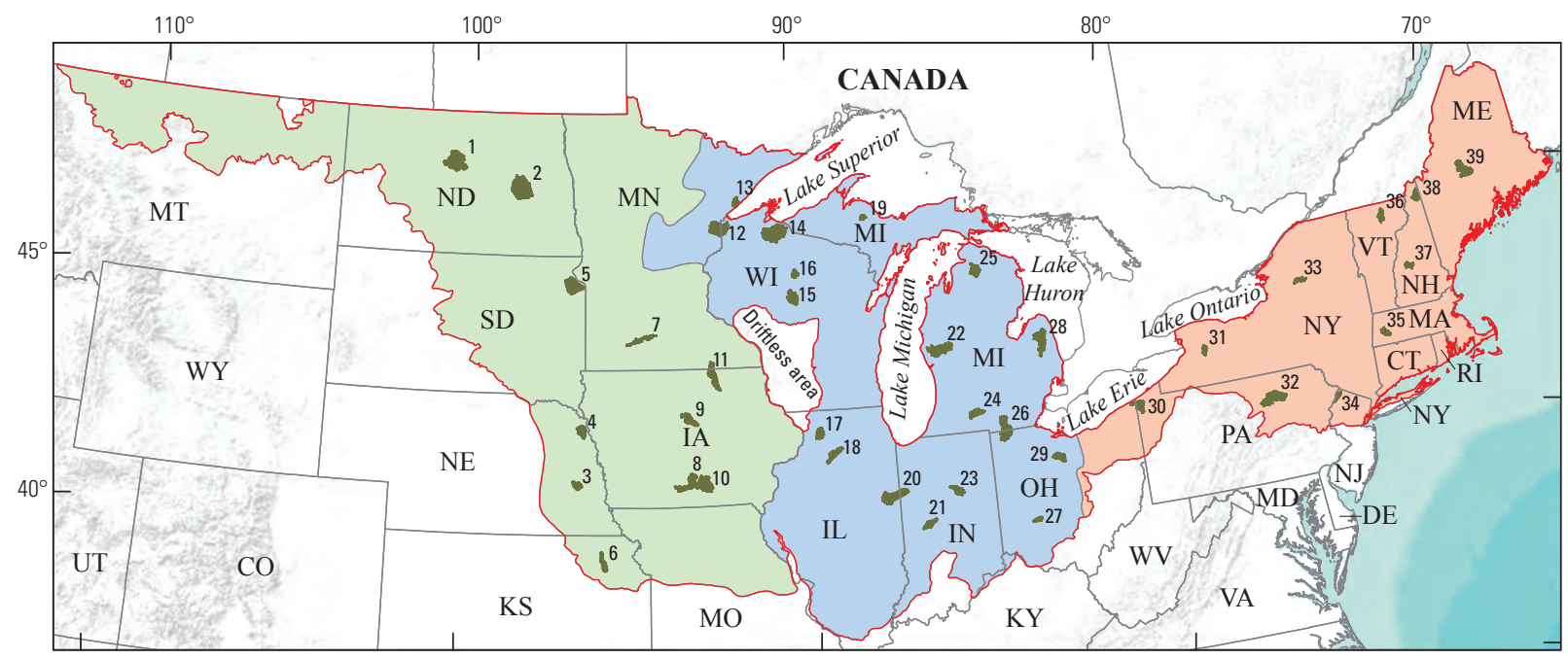

Base map image is the intellectual property of Esri and is used herein under license. Copyright (c) 2017 Esri and its licensors. All rights reserved. Base modified from Esri digital data, 1:70,000 (Esri, 2009)

Base map of states from U.S. Geological Survey 1:2,000,000 digital data

Albers Equal-Area Conic projection, standard parallels $29^{\circ} 30^{\prime}$ N., and $45^{\circ} 30^{\prime} \mathrm{N}$.

Central meridian $96^{\circ} 00^{\prime}$ W., latitude of origin $23^{\circ} 00^{\prime} \mathrm{N}$.

\section{EXPLANATION}

$\square$ Extent of glacial Soil-Water-Balance model domain
Basins used for model calibration, labeled by map number
Glacial region
Central
East
West central

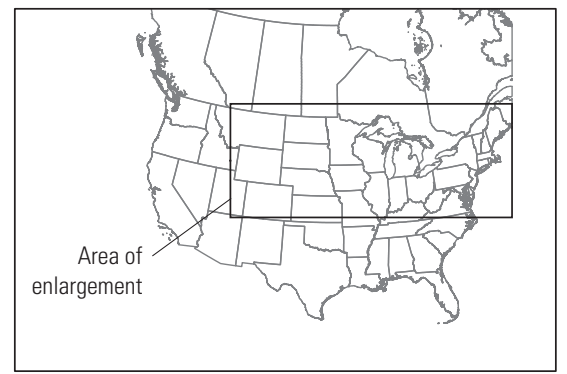

Figure 1. Extent of the glacial aquifer system included in the domain of the glacial Soil-Water-Balance model and the basins used for model calibration.

changes in groundwater availability include the introduction of poor water quality from natural or anthropogenic constituents, concerns of conflicts with current groundwater users, or the desire to maintain or restore environmental streamflows.

Quantifying sustainable water withdrawal rates for human use requires careful consideration of inputs (recharge) to and losses from groundwater systems at a variety of spatial and temporal scales. Sustainable withdrawals ensure that terrestrial and aquatic ecosystems and future water resources for human needs are not adversely affected by overuse. Groundwater recharge replenishes water lost from aquifers by processes such as evapotranspiration (ET), discharge to surface water, seepage to other aquifers, and pumping withdrawals. Groundwater recharge is challenging to quantify because of variability in time and space caused by many factors, such as multiyear climate trends, seasonal weather patterns, hydrogeologic properties, land use, and land cover. An understanding of the spatial and temporal extent of groundwater recharge is critical for many types of hydrologic assessments involving water quality, contaminant transport, ecosystem health, and groundwater availability; for example, recharge to groundwater in semiarid or arid regions may be so low that withdrawals from the system lead to groundwater mining and depletion of the resource.
The combined effect of lower recharge and higher demand may be transient but can result in undesired consequences, such as land subsidence, temporary streamflow depletion, water levels dropping below the level of existing pumps or wells, and migration of poor-quality water into the aquifer. Seasonal, annual, or decadal variations in climate can lead to changes in the recharge to the groundwater system and the demands on the system for public, domestic, irrigation, and industrial supply; therefore, modeling recharge using only average conditions fails to incorporate extremes in climatic variations and water use. Failure to incorporate these extremes may result in undesired consequences that affect aquatic ecosystem health, human water supply, and public safety (Reeves and others, 2017).

\section{Purpose and Scope}

The purpose of this report is to document the calibration and use of the Soil-Water-Balance (SWB) model (Westenbroek and others, 2010) to simulate potential recharge for the glacial aquifer system east of the Rocky Mountains in the conterminous United States at a 1-kilometer $(\mathrm{km})$ resolution for 1980-2011. This report is prepared as part of the 
U.S. Geological Survey's (USGS) Glacial Aquifer System Groundwater Availability Study, which assesses groundwater availability for the glacial aquifer system of the United States. The SWB model was calibrated to base-flow estimates calculated from daily streamflow data by the HYSEP local minimum method (Sloto and Crouse, 1996) for 39 basins across the glacial aquifer system. A total of five base-flow separation techniques were compared as calibration targets. The HYSEP local minimum method was chosen because it produced estimates in the midrange of the five methods. Calibration targets for each basin included the mean annual base flow, annual total base flow, and annual total base-flow deciles.

The model was calibrated initially with parameter values from previously published SWB recharge models (Aurand, 2013; Masterson and others, 2013; Metropolitan Council Environmental Services, 2013; Smith and Westenbroek, 2015; Westenbroek and others, 2010). A sensitivity analysis was completed to understand how the SWB model responds to changes in some important parameters and inputs. Although potential recharge estimates and most model inputs are in U.S. customary units, spatial data such as model grid spacing and some model inputs use the International System of Units.

\section{Description of the Study Area}

The subset of the glacial aquifer system in the United States included in this study extends from central Montana east to Maine (fig. 1). The system is made of material deposited by the Laurentide ice sheet that extended into North America in a series of advances and retreats of continental glaciers between 2.5 million and 12,000 years ago (Booth and others, 2003; Dorr and Eschman, 1970; Marshall and others, 2003; Mickelson and Colgan, 2003). In some areas, more recent glaciation removed old material, and glacially deposited material is only from the last advance. In other areas, glacial deposits are from sequential ice sheet advances and retreats. Glacial landforms have material that affects groundwater yield, aquifer hydraulic properties, and, ultimately, groundwater availability at local and regional scales (Anderson, 1989; Eyles, 1983; Eyles and others, 1985). For this report, all unconsolidated materials within the glaciated parts of the conterminous United States are considered to be of the glacial aquifer system even if the material has been deposited more recently by mechanisms other than glaciation (Reeves and others, 2017). One unique unglaciated feature in the Midwest is the Driftless Area (fig. 1), which is a highly eroded landscape with shallow soils overlying Paleozoic bedrock (Albert, 1994).

The extent of the model presented in this report is a subset of the glacial aquifer system study area established for the USGS National Water-Quality Assessment (Warner and Arnold, 2006). This report only discusses the east, central, and west-central regions of the glacial aquifer system (fig. 1). The west region of the glacial aquifer system, which corresponds to the extent of the Cordilleran ice sheet advance in western Montana, Idaho, Washington, and Alaska, was excluded from this model application (see fig. 1 in Warner and Arnold, 2006); however, the extent of the model includes the glaciated extent, not just the extent of the glacial sand and gravel principal aquifer (Miller, 1999). Water supplying wells for domestic water supply, irrigation, and industrial use may be produced from glacial deposits with low hydraulic conductivity or local units of isolated sand or gravel that typically are not mapped as sand and gravel aquifers. Deposits with lower hydraulic conductivity also contribute important storage to the system and can be important to water availability and water-quality characteristics anywhere in the system (Reeves and others, 2017).

\section{Definition of Potential Groundwater Recharge for this Report}

A variety of mechanisms, only a subset of which are represented by the SWB model in this report, can lead to groundwater recharge. Recharge is defined conceptually as the downward flow of water reaching the water table, forming an addition to the groundwater reservoir (de Vries and Simmers, 2002).

Lerner and others (1990) define three principal recharge mechanisms to a groundwater system: (1) direct recharge is water added to the groundwater reservoir in excess of soilmoisture deficits and ET by direct vertical percolation through the vadose zone; (2) indirect recharge is percolation to the water table through the beds of surface-water courses; and (3) localized recharge is an intermediate form of groundwater recharge resulting from the horizontal (near-) surface concentration of water in the absence of well-defined channels. The glacial SWB model is conceptualized as only representing the direct recharge mechanism (fig. 2) and does not explicitly consider indirect or localized recharge mechanisms.

Recharge estimation techniques like SWB that are based on surface-water and unsaturated-zone data provide estimates of potential recharge in contrast to methods based on groundwater data, which generally provide estimates of actual recharge (Healy and Scanlon, 2010). Therefore, the SWB model estimates potential direct recharge, defined as precipitation water in excess of interception, runoff, ET, and soil-water storage capacity that infiltrates vertically below the plant rooting zone that is assumed to reach the water table. In this report, the term "recharge" in the context of any estimate determined using the SWB model is synonymous with potential direct recharge.

\section{Previous Studies}

Numerous methods have been used to estimate groundwater recharge at various temporal and spatial scales (Scanlon and others, 2002). Important considerations for the selection of an appropriate recharge estimation method include: (1) the time scale of interest, (2) the need for static or transient estimates, (3) spatial scale of the recharge estimates, 


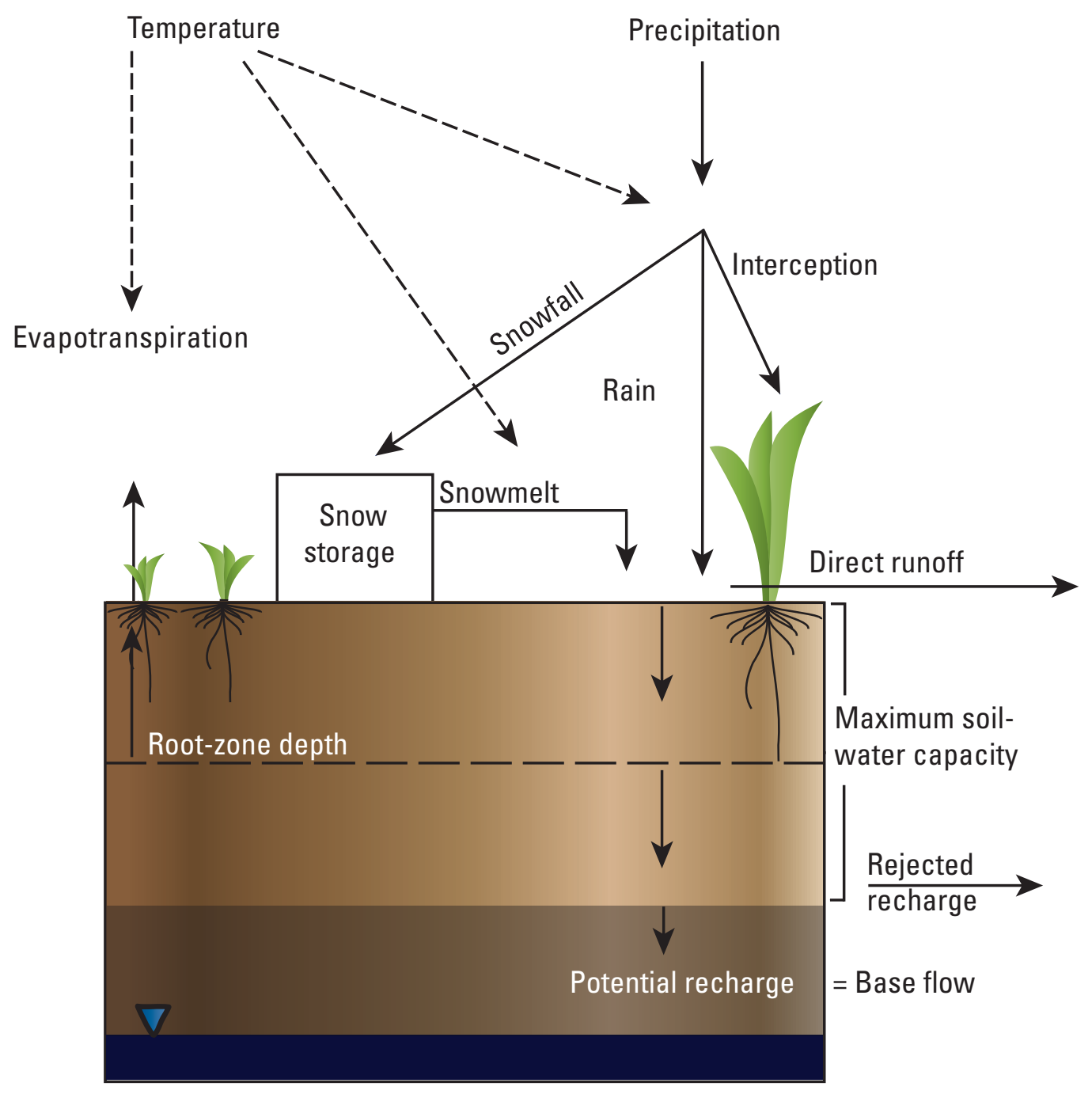

Figure 2. Conceptual diagram of the Soil-Water-Balance model.

(4) availability of the necessary data, and (5) the ease of use of the recharge estimation method or model (Scanlon and others, 2002). In this report, only two methods of recharge estimation, hydrograph separation and SWB model applications, will be discussed in detail. Both methods have been applied previously at broad spatial and temporal scales (as discussed below) and are well suited to estimate time-varying recharge across the glacial aquifer system.

Many regional studies have used some form of hydrograph separation to estimate the spatial distribution of groundwater recharge (for example, Arnold and Allen, 1999; Neff and others, 2006; Wolock, 2003a; Wolock, 2003b). The base flow of a stream or river is the amount of groundwater discharged from an aquifer to surface water. Over the course of a year, assuming there is no trend in the quantity of water stored in the aquifer, the total base flow is assumed to equal the total groundwater recharge for a basin (watershed). This base flow is supplemented by direct runoff during and immediately after precipitation or snowmelt, resulting in peaks on hydrographs. The process of dividing these peaks into base flow and runoff (overland flow) is called hydrograph separation (Neff and others, 2005).

Various mathematical approaches are used for hydrograph separation, including (1) digital filtering (Arnold and others, 1995; Eckhardt, 2005; Nathan and McMahon, 1990), (2) recession-curve methods (Chapman, 1999; Rorabaugh, 1964), and (3) linear interpolation methods (Gustard and others, 1992; Rutledge, 1998; Sloto and Crouse, 1996). The minimum time scale for these methods is a few months, but a time scale of a year or longer typically is used. Recharge over longer times can be estimated by summation of estimates over shorter times (Scanlon and others, 2002). Generally, average annual estimates are more reliable than monthly or daily estimates of base flow or surface runoff (Sloto and Crouse, 1996). The following paragraphs describe a few example applications of hydrograph separation. 
Wolock (2003b) estimated the mean annual natural groundwater recharge in the conterminous United States for a 1-km resolution (grid) dataset for 1951-80. This 1-km grid was created by multiplying a grid of base-flow index values (the ratio of base flow to total streamflow) by a grid of mean annual runoff values derived from a mean annual runoff contour map for 1951-80. Mean annual runoff is the 1951-80 mean annual streamflow expressed on a per-unit-area basis. The base-flow index point values were computed according to the base-flow index (BFI) method, described in Gustard and others (1992). The base-flow index point values estimated for USGS streamgages were interpolated to a raster dataset using an inverse distance weighting interpolation method (Wolock, 2003a).

In another example regional study, Neff and others (2006) calculated the long-term average groundwater recharge to shallow aquifers (generally less than 100 feet [ft] deep) in the United States and Canada for the eight-digit hydrologic unit code (HUC) watersheds within the Great Lakes Basin in gaged and ungaged watersheds. The base-flow index was estimated from the PART hydrograph separation method (Rutledge, 1998). In gaged areas, the base-flow index values were related to surficial geologic materials and surface-water features in a regression model. In ungaged watersheds, the regression model that was developed in gaged watersheds was used to predict base-flow index values based on their surficial geology and surface-water features. The predicted base-flow index then was multiplied by the long-term average total streamflow at the eight-digit HUC level to get a long-term average recharge per year (Neff and others, 2006).

The previous two example studies produced long-term average rates of groundwater recharge for large spatial extents, but the estimates did not vary through time. A series of studies done in Wisconsin demonstrated that temporal trends in annual base flow or low flow varied by land use and geology (Gebert and others, 2011a, 2011b; Gebert and others, 2007; Gebert and Krug, 1996). For example, a significant increasing trend in base flow was observed in agricultural watersheds and the driftless area (fig. 1), whereas most forested watersheds had no significant trend in base flow. Similar to these studies in Wisconsin, the SWB model produces time-varying estimates of groundwater recharge.

The SWB model commonly is compared to recharge estimates derived from hydrograph separation and takes advantage of nationally consistent meteorological, land-cover, and soil hydrology datasets to simulate recharge across the landscape at user-defined resolutions (Fry and others, 2011; Homer and others, 2007, 2015; Natural Resources Conservation Service, 2015; Thornton and others, 2014). The SWB model code has been used to estimate spatially and temporally variable potential recharge for several diverse regional systems across the United States, some of which overlap the model domain in this report. A few previous SWB model applications include the State of Minnesota (Smith and Westenbroek, 2015), the Lake Michigan Basin (Feinstein and others, 2010;
Westenbroek and others, 2010), the High Plains aquifer (Stanton and others, 2011), the Williston and Powder River Basins (Aurand, 2013), the North Atlantic Coastal Plain (Masterson and others, 2013), and the Appalachian Plateaus (McCoy and others, 2015).

The Lake Michigan Basin, Minnesota, and Appalachian Plateaus SWB models were calibrated to recharge estimates derived from the base-flow component of hydrographs (Feinstein and others, 2010; McCoy and others, 2015; Smith and Westenbroek, 2015; Westenbroek and others, 2010). An SWB model that has been calibrated to base flow distributes that volume of water at the time step of interest throughout a watershed based on land-cover and soil hydrology characteristics. The Lake Michigan Basin SWB model was calibrated by iteratively modifying model parameters such as the runoff curve number, soil available water capacity, and rooting depth to increase the correspondence between 10-year mean potential recharge values calculated by the SWB model and the recharge calculated for 100 basins associated with USGS streamgages (Westenbroek and others, 2010). The Minnesota SWB model was calibrated using a combination of automated and manual parameter adjustment processes. The calibration targets were annual base flows during 1996-2010 and the 15 -year mean base flow in 35 watersheds estimated with 3 different techniques, including PART (Rutledge, 1998) and HYSEP fixed interval and sliding methods (Sloto and Crouse, 1996). The Appalachian Plateaus SWB model was calibrated by adjusting three parameter groups: root-zone depth, runoff curve number, and plant-canopy interception values. The calibration targets were annual base flows estimated with PART in 20 gaged watersheds with at least 24 years of record (McCoy and others, 2015).

Several SWB models were not calibrated directly to base flow but were compared to other types of recharge estimates or were calibrated as part of the calibration exercise for groundwater modeling (Anderson and others, 2015). The Williston and Powder River Basin SWB model output covered parts of Montana, Wyoming, North Dakota, and South Dakota. Model outputs were compared to point estimates of recharge at specific wells calculated by the water-table fluctuation method and the chloride mass balance method (Aurand, 2013). The High Plains aquifer SWB model output was compared to the SOil WATer (SOWAT) model (Kahle and others, 2011) and 43 local and regional studies published for various locations across the High Plains aquifer. The sensitivities of a subset of model parameters were reported, but the SWB model was not calibrated to any hydrologic measurements of water levels or streamflow (Stanton and others, 2011). For the North Atlantic Coastal Plain SWB model, the model parameters of available water capacity, runoff curve number, and rooting depths were derived from previously published studies, and model calibration processes were not specified. The average annual potential recharge rate from the SWB model output was compared to 17 previously published recharge estimates within the study area (Masterson and others, 2013). 


\section{Methods}

This section contains a brief discussion of the SWB model theory and how the input datasets for the glacial SWB model were prepared. Also included are discussions of the model calibration process and methods used for evaluating model fit and error.

\section{Model Theory and Description}

The SWB model uses a modified Thornthwaite-Mather soil-water-balance approach (Thornthwaite and Mather, 1955, 1957) to estimate daily potential recharge. Recharge estimates can be imported into regional groundwater-flow models or other hydrologic assessments where spatially distributed recharge estimates are necessary. Also, the gridded approach of the SWB model allows for potential recharge estimates to be rescaled to match the resolution of grid-based groundwater-flow model.

The SWB model uses a soil-water accounting method to calculate potential recharge separately for each grid cell in the model domain (Westenbroek and others, 2010). Potential recharge is calculated daily within each grid cell of the model domain as the difference between sources (liquid precipitation, snowmelt, upslope inflow), sinks (interception, outflow [runoff], ET), and change in soil moisture (eq. 1):

$$
\begin{gathered}
\text { recharge }=(\text { precipitation }+ \text { snowmelt }+ \text { inflow })- \\
(\text { interception }+ \text { outflow }+ \text { evapotranspiration }) \\
-\Delta \text { soil moisture }
\end{gathered}
$$

Each of the water-budget components in equation 1 is handled by one or more modules within the SWB model. The SWB model has the capability for routing runoff through the model domain; however, runoff routing was not used in this modeling application because the grid scale $(1 \mathrm{~km})$ was sufficiently large so that overland flow was expected to infiltrate within a grid cell before entering an adjacent cell. Computation of water-budget components relies on relations between surface runoff, land cover, and hydrologic soil group (HSG) (Cronshey and others, 1986) and estimated values of ET. Water storage in the soil column was estimated daily using a modified Thornthwaite-Mather accounting method (Westenbroek and others, 2010). A brief summary of model processes is shown in figure 2. Additional theoretical and background details about the SWB model processes are detailed in Westenbroek and others (2010). For the glacial SWB model in this report, algorithms as described in Westenbroek and others (2010) were used for determining precipitation type (liquid or snow), snowmelt timing and rates, periods of frozen soil, runoff volumes according to the curve number method, and daily changes in soil moisture with the necessary intermediary values. Interception and the start and end of the growing season were determined with separate algorithms not described in Westenbroek and others (2010) and are described in the "Lookup Tables and Control File" section.

\section{Model Limitations and Assumptions}

The original concept behind the SWB model code was to allow for the spatial distribution of potential groundwater recharge to be quickly and easily calculated from readily available data and standardized parameters (Dripps and Bradbury, 2007; Westenbroek and others, 2010); however, SWB results are typically not directly constrained by measured field data and thus should be corroborated with recharge estimates generated from other methods. The SWB model described in this report is intended to provide information about the distribution of potential recharge in time and space at a $1-\mathrm{km}$ scale for annual to multiyear timescales. Although SWB approaches are a preferred approach for groundwater modeling (Anderson and others, 2015), comparing the SWB-calculated potential recharge estimates from the current model to recharge estimated from groundwater-level fluctuations, hydrograph separation, or other methods in a particular area of interest is highly recommended. Multiple methods of indirect measurement and associated errors frequently are compared because potential recharge rates cannot be measured easily across large areas (Healy and Scanlon, 2010).

The SWB model was calibrated to stream base flows determined using hydrograph separation. Hydrograph separation methods require several simplifying assumptions (adapted from McCoy and others, 2015):

1. Streamflow hydrographs only reflect contributions from two sources: surface runoff from precipitation and base flow resulting from groundwater discharge to streams.

2. Direct, diffuse groundwater recharge happens throughout a basin, as opposed to indirect recharge through streambeds.

3. Groundwater discharge to streams is a continuous process (Healy and Scanlon, 2010).

4. All groundwater recharge within the basin discharges to the receiving stream network.

5. Groundwater contributing areas are perfectly coincident with surface-watershed boundaries.

6. Groundwater storage within the basin does not change over the period of interest.

7. The base-flow component of streamflow is all groundwater discharge and does not result from other factors that create a stable flow signal such as slow snowmelt, streamflow regulation, or wastewater return flows.

The hydrograph separation techniques used in this report are appropriate only when used over a period of 1 year or more (Rutledge, 1998; Sloto and Crouse, 1996). Assuming that base flow from hydrograph separation is equal to groundwater recharge requires a period of analysis that is long 
enough so that the effect on the water balance of changes in storage can be considered negligible (Rutledge, 1998). This critical assumption likely is met most consistently across the model domain for the 1980-2011 period, making the 32-year mean annual potential recharge the most reliable estimate from this SWB model application. The annual potential recharge estimates (that is, the potential recharge total for each of the 32 years of the simulation) were useful in that they demonstrated the temporal variability in potential recharge under changing climatic and land-use conditions. Groundwater contributing areas do not always coincide with surface-watershed boundaries (Kanivetsky, 1979), but surface-watershed boundaries are assumed to be an adequate approximation of groundwater contributing areas for the purposes SWB model calibration and is consistent with previous SWB model applications (McCoy and others, 2015; Smith and Westenbroek, 2015; Westenbroek and others, 2010).

Base flow used to calibrate the SWB model is an estimate of groundwater recharge that has an absolute minimum error of 5 percent (from streamflow measurement error), though the actual error likely is greater than this minimum. Hydrograph separation methods are applied to streamflow measurements, which themselves have variable error rates. Streamflow measurements made by the USGS typically are rated as "good," "fair," or "poor," which correspond to approximate error rates of 5, 8, or 10 percent, respectively (Turnipseed and Sauer, 2010). Differing amounts of error also are introduced from the hydrograph separation method and the characteristics of the watershed where the method is applied.

The five hydrograph separation methods used in this report produced variable estimates of base flow, as discussed in the "Model Fit and Model Error" section. Certain flow conditions in watersheds, such as flow regulation structures, slow snowmelt, tile drainage, or wastewater discharge contribute to a streamflow signal that mimics groundwater discharge and may result in overestimates of base flow, and thus overestimates of groundwater recharge (Schilling and Helmers, 2008; Sloto and Crouse, 1996). For the SWB model calibration, criteria were used to select calibration basins such that these types of error were minimized (refer to "Calibration Targets" section); nevertheless, these errors were inevitable in varying amounts in the calibration basins.

Subsurface drainage tiles are used extensively throughout the Midwest to lower the water table and drain soils that are seasonally or perennially wet so that those areas can be used for agricultural production (Madramootoo and others, 2007; Zucker and Brown, 1998). Tile drainage can increase the base-flow component determined with hydrograph separation but may not represent the timing of natural groundwater seepage into streams (for example, Schilling and Helmers, 2008). Nationally consistent tile drainage records are not available, and assessing the density of tile drainage in each of the calibration basins was beyond the scope of this study; however, a map of drained land density in the United States (Madramootoo and others, 2007) indicates that calibration basins in southern Minnesota, Iowa, Illinois, southern
Michigan, Indiana, and Ohio (fig. 1) have a high likelihood of being affected by tile drain flow. Therefore, it is possible that results from glacial SWB model calibration might have tiledrain artifacts from hydrograph separation done for heavily tile-drained watersheds in the Midwest.

Model results should not be used for periods of less than 1 year because the SWB model does not account for lag times resulting from transport in the unsaturated zone, which affects timing between precipitation events and related groundwater recharge (Hunt and others, 2008). Even yearly estimates of potential recharge only should be used as an approximate range of potential recharge rates. Potential recharge in the SWB model is assumed to happen instantaneously within the daily time step, whereas actual recharge can take months or even years. An annual time step requires the assumption that all potential recharge happening on the landscape within a basin is measured at the streamgage during that same year. This assumption does not hold where there are flow paths with long travel times to the stream of interest. Aggregating SWB recharge annually also assumes no change in basin storage over a year. It should be noted, however, that when SWB results are linked to groundwater modeling, it is possible to account for unsaturated zone recharge lags (Hunt and others, 2008).

Precipitation is aggregated to the daily time step to limit the model run time, and the daily time step generally is the smallest time step available in large meteorological datasets; however, for an equal amount of precipitation, surface runoff will differ between a 30-minute storm and steady rainfall lasting several hours., The SWB model cannot distinguish between these two events based on the daily time step (Smith and Westenbroek, 2015).

The glacial SWB model domain covers an immense study area and does not simulate all combinations of land cover, soil types, and climate equally well. Within the SWB model code, potential recharge is calculated as the difference between sources and sinks (eq. 1), so any errors in the various hydrologic components will be superimposed on the potential recharge error. The errors associated with different hydrologic components are not distributed equally throughout the model; a few specific cases of expected greater error are described below.

The SWB code is best suited for conditions in which the water table is below the root-zone depth (fig. 2). The SWB model does not record the depth to the water table. The SWB model cannot directly account for ET taken directly from the groundwater system, nor can it reject recharge based on reduced subsurface storage resulting from high water tables (Westenbroek and others, 2010); therefore, some of the major hydrologic processes in areas with abundant wetlands, springs, lakes, or other landscape features where the water table regularly intersects the land surface are not represented in the SWB code, which could result in simulations that differ substantially from observed conditions. All open-water features, such as lakes, ponds, and large rivers, were assumed to have no direct potential recharge; exchanges between surface-water and 
groundwater features are not simulated explicitly in the SWB code. Parts of the model domain receive substantial amounts of precipitation as snowfall. The SWB code uses a continuous frozen ground index (CFGI), based on air temperature, to assign the runoff curve number of model cells between antecedent moisture conditions II (unfrozen) and III (frozen). As the percentage of precipitation that falls as snow increases, errors associated with snowmelt infiltration likely become larger. For additional discussion on the limitations of the SWB model code, refer to Westenbroek and others (2010).

\section{Model Input Data}

The glacial SWB model consists of a 1-km grid spacing of 1,374 rows and 3,548 columns. The rectangular model domain extent was defined by the extent of the glacial aquifer system as outlined in figure 1. Of the nearly 4.9 million model cells within that area, only approximately 1.8 million are within the boundaries of the glacial aquifer system and active for the SWB model simulations.

The SWB model requires input for parameters that govern the simulation of hydrologic processes for each land use-soil type combination within a model domain. The following gridded datasets were required to use the SWB model to calculate potential recharge on a cell-by-cell basis, as detailed in Westenbroek and others (2010): (1) meteorological data (daily precipitation in inches, daily maximum air temperature, daily minimum air temperature), (2) land-cover class, (3) HSG, and (4) available soil-water capacity.

An optional grid for surface-water flow direction, which routes overland flow between cells, was not included as part of the glacial SWB model. The lookup tables for (1) soil and land cover and (2) soil-water retention are necessary for the SWB code to run. Details of these two lookup tables are given in the "Lookup Tables and Control File" section.

\section{Meteorological Data}

All the potential recharge estimates in this report were based on meteorological data from the Daymet dataset (Thornton and others, 2014). Daymet data are daily continuous surfaces of meteorological data, including precipitation and daily minimum/maximum air temperature, which have been applied broadly in hydrological and terrestrial vegetation growth models (Thornton and others, 1997). Mean annual gross precipitation in inches per year (in/yr) for 1980-2011 at a $1-\mathrm{km}$ resolution from the Daymet dataset is shown in figure 3.

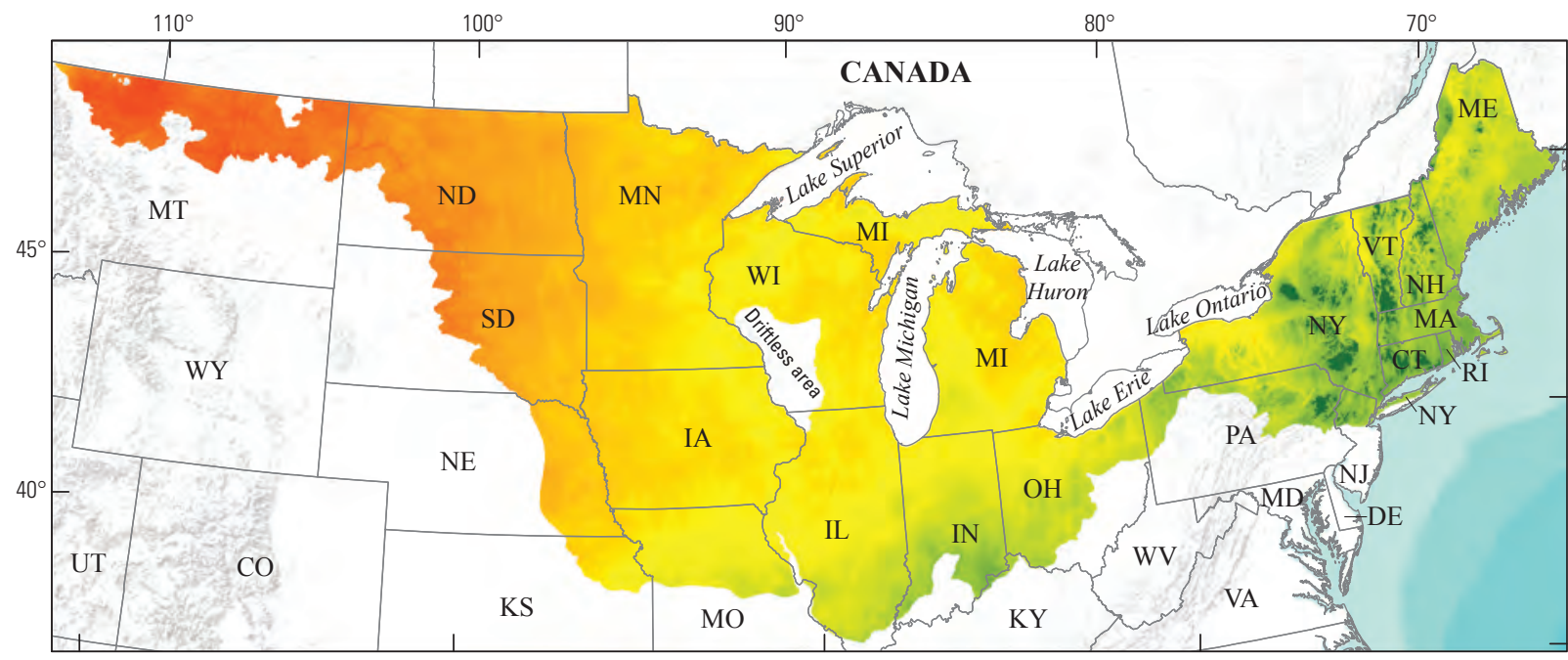

Base map image is the intellectual property of Esri and is used herein under license. Copyright $(\complement 2017$ Esri and its licensors. All rights reserved. Base modified from Esri digital data, 1:70,000 (Esri, 2009)

Base map of states from U.S. Geological Survey 1:2,000,000 digital data Albers Equal-Area Conic projection, standard parallels 29 ${ }^{\circ} 30^{\prime} \mathrm{N}$., and $45^{\circ} 30^{\prime} \mathrm{N}$. Central meridian $96^{\circ} 00^{\prime} \mathrm{W}$., latitude of origin $23^{\circ} 00^{\prime} \mathrm{N}$.

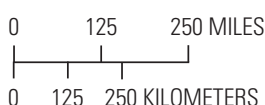

0 $125 \quad 250$ KILOMETERS

EXPLANATION

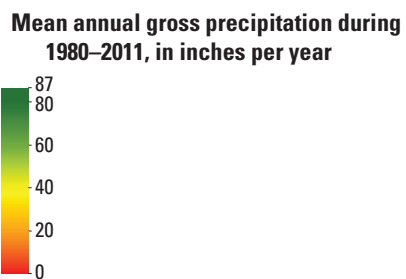

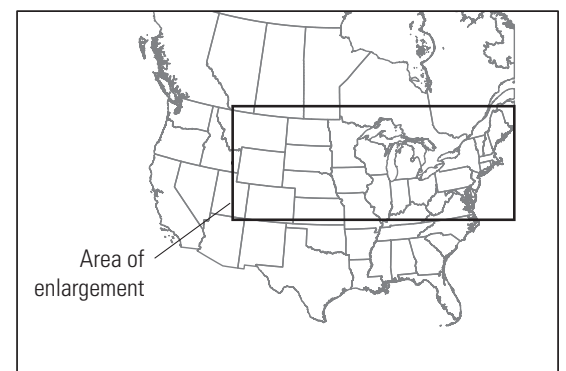

Figure 3. Mean annual gross precipitation within the extent of the glacial aquifer system at a 1-kilometer resolution for 1980-2011, summarized from the Daymet dataset (Thornton and others, 2014). 


\section{Land Cover}

Input land-cover data for the SWB model were derived from the National Land Cover Database (NLCD) dataset for the reference years of 2001 (Homer and others, 2007), 2006 (Fry and others, 2011), and 2011 (Homer and others, 2015). The use of NLCD products incorporates a consistent classification scheme that captures the spatial and temporal variability in land use over the model domain through time. The 2001 NLCD dataset was used for 1980 to 2003, the 2006 NLCD was used for 2004 to 2008, and the 2011 NLCD was used for 2009 to 2011. The NLCD characterizes land cover into 16 categories at a 30-meter $(\mathrm{m})$ resolution. Input datasets were resampled from the native 30-m resolution of the NLCD to $1-\mathrm{km}$ resolution using a majority resampling protocol in Esri ArcMap 10.1 (Esri, 2012) and exported to an American Standard Code for Information Interchange (ASCII) data grid for use in the SWB model.

Of the 16 land-cover classes, 15 are in the active SWB model domain (tables 1, 2, 3, fig. 4). At 1-km resolution, no land-cover class changed by more than 0.2 percent among the 2001, 2006, and 2011 datasets. Cultivated crops (landcover class 82) covered the largest area (38 percent) of the model domain. The second largest land-cover class was forest, covering about 25 percent of the model domain. Within the forest classification, deciduous forest covered 18 percent, and evergreen and mixed forests covered less than 4 percent each (tables 1, 2, 3, fig. 4).

\section{Soil Hydrologic Data}

The glacial SWB model required two input grids of soil hydrologic characteristics: HSG and available water capacity (AWC). Each cell within the model domain was assigned to an HSG and assigned an AWC value. Both grids were derived from the Digital General Soil Map of the United States (STATSGO2) dataset (Natural Resources Conservation Service, 2015). STATSGO2 is described as "a broad-based inventory of soils and non-soil areas that occur in a repeatable pattern on the landscape and that can be cartographically shown at the scale mapped of 1:250,000 in the continental U.S.” (Natural Resources Conservation Service, 2015).

The 1-km HSG and AWC grids were derived from areaand depth-weighted averages of hydrologic variables in the STATSGO2 dataset. The area- and depth-weighted averages were computed on a 100-m grid scale using methods originally applied to the Soil Survey Geographic (SSURGO) dataset as described in Wieczorek (2014). The area- and depthweighted STATSGO2 data are preliminary and are subject to revision. The processed STATSGO2 data have not received final approval by the U.S. Geological Survey (USGS).

\section{Hydrologic Soil Group}

The 100-m HSG grid (Michael Wieczorek, written commun., January 16, 2015) was resampled to 1-km resolution using a majority resampling protocol in Esri ArcMap 10.1

Table 1. Percentage of the glacial aquifer system by 2001 land-cover class from the National Land Cover Database dataset (Homer and others, 2007) and the Digital General Soil Map of the United States (STATSG02) hydrologic soil group (Natural Resources Conservation Service, 2015).

[The total number of active square kilometer cells in the model domain is 1,736,651; NA, not applicable; --, no data]

\begin{tabular}{|c|c|c|c|c|c|c|c|c|}
\hline \multirow[b]{2}{*}{$\begin{array}{l}\text { Land- } \\
\text { cover } \\
\text { class }\end{array}$} & \multirow[b]{2}{*}{ Description } & \multicolumn{7}{|c|}{ Percentage of domain } \\
\hline & & $\begin{array}{c}\text { Hydrologic } \\
\text { soil group } \\
\text { A }\end{array}$ & $\begin{array}{c}\text { Hydrologic } \\
\text { soil group } \\
\text { B }\end{array}$ & $\begin{array}{c}\text { Hydrologic } \\
\text { soil group } \\
\text { C }\end{array}$ & $\begin{array}{c}\text { Hydrologic } \\
\text { soil group } \\
\text { D }\end{array}$ & $\begin{array}{l}\text { Organic soil } \\
\text { group }\end{array}$ & $\begin{array}{l}\text { Open } \\
\text { water }\end{array}$ & $\begin{array}{l}\text { Glacial } \\
\text { domain total } \\
\text { land cover }\end{array}$ \\
\hline 11 & Open water & 0.259 & 0.947 & 0.478 & 0.135 & 0.063 & 1.259 & 3.1 \\
\hline 21 & Developed, open space & 0.351 & 1.437 & 0.958 & 0.164 & 0.035 & 0.005 & 3.0 \\
\hline 22 & Developed, low intensity & 0.262 & 0.943 & 0.599 & 0.113 & 0.018 & 0.003 & 1.9 \\
\hline 23 & Developed, medium intensity & 0.116 & 0.332 & 0.247 & 0.035 & 0.006 & 0.001 & 0.7 \\
\hline 24 & Developed, high intensity & 0.048 & 0.126 & 0.084 & 0.013 & 0.003 & 0.001 & 0.3 \\
\hline 31 & Barren land (rock/sand/clay) & 0.03 & 0.05 & 0.05 & 0.024 & 0.005 & 0.009 & 0.2 \\
\hline 41 & Deciduous forest & 2.205 & 5.988 & 8.405 & 0.728 & 0.325 & 0.024 & 17.7 \\
\hline 42 & Evergreen forest & 0.784 & 0.472 & 1.925 & 0.303 & 0.108 & 0.015 & 3.6 \\
\hline 43 & Mixed forest & 0.397 & 0.448 & 2.569 & 0.214 & 0.067 & 0.008 & 3.7 \\
\hline 52 & Shrubland & 0.183 & 0.21 & 0.651 & 0.208 & 0.027 & 0.003 & 1.3 \\
\hline 71 & Grasslands & 0.477 & 4.287 & 2.053 & 1.947 & 0.022 & 0.026 & 8.8 \\
\hline 81 & Pasture/hay & 0.501 & 5.131 & 3.911 & 0.736 & 0.076 & 0.004 & 10.4 \\
\hline 82 & Cultivated crops & 1.145 & 24.532 & 9.728 & 2.306 & 0.21 & 0.007 & 37.9 \\
\hline 90 & Woody wetlands & 0.996 & 1.783 & 1.483 & 0.306 & 1.165 & 0.024 & 5.8 \\
\hline 95 & Herbaceous wetlands & 0.226 & 0.715 & 0.284 & 0.079 & 0.339 & 0.029 & 1.7 \\
\hline NA & Glacial domain total in soil group & 8.0 & 47.4 & 33.4 & 7.3 & 2.5 & 1.4 & -- \\
\hline
\end{tabular}


Table 2. Percentage of the glacial aquifer system by 2006 land-cover class from the National Land Cover Database dataset (Fry and others, 2011) and the Digital General Soil Map of the United States (STATSG02) hydrologic soil group (Natural Resources Conservation Service, 2015).

[The total number of active square kilometer cells in the model domain is $1,736,651$; NA, not applicable; --, no data]

\begin{tabular}{|c|c|c|c|c|c|c|c|c|}
\hline \multirow[b]{2}{*}{$\begin{array}{l}\text { Land- } \\
\text { cover } \\
\text { class }\end{array}$} & \multirow[b]{2}{*}{ Description } & \multicolumn{7}{|c|}{ Percentage of domain } \\
\hline & & $\begin{array}{c}\text { Hydrologic } \\
\text { soil group } \\
\text { A }\end{array}$ & $\begin{array}{c}\text { Hydrologic } \\
\text { soil group } \\
\text { B }\end{array}$ & $\begin{array}{c}\text { Hydrologic } \\
\text { soil group } \\
\text { C }\end{array}$ & $\begin{array}{c}\text { Hydrologic } \\
\text { soil group } \\
\text { D }\end{array}$ & $\begin{array}{l}\text { Organic soil } \\
\text { group }\end{array}$ & $\begin{array}{c}\text { Open } \\
\text { water }\end{array}$ & $\begin{array}{c}\text { Glacial } \\
\text { domain total } \\
\text { land cover }\end{array}$ \\
\hline 11 & Open water & 0.255 & 0.911 & 0.473 & 0.132 & 0.063 & 1.229 & 3.1 \\
\hline 21 & Developed, open space & 0.346 & 1.472 & 0.974 & 0.171 & 0.032 & 0.005 & 3.0 \\
\hline 22 & Developed, low intensity & 0.282 & 0.979 & 0.619 & 0.115 & 0.021 & 0.003 & 2.0 \\
\hline 23 & Developed, medium intensity & 0.117 & 0.344 & 0.25 & 0.037 & 0.006 & 0.001 & 0.8 \\
\hline 24 & Developed, high intensity & 0.05 & 0.132 & 0.088 & 0.013 & 0.004 & 0.001 & 0.3 \\
\hline 31 & Barren land (rock/sand/clay) & 0.029 & 0.052 & 0.05 & 0.024 & 0.005 & 0.009 & 0.2 \\
\hline 41 & Deciduous forest & 2.211 & 5.998 & 8.392 & 0.724 & 0.33 & 0.024 & 17.7 \\
\hline 42 & Evergreen forest & 0.768 & 0.468 & 1.952 & 0.306 & 0.109 & 0.016 & 3.6 \\
\hline 43 & Mixed forest & 0.402 & 0.454 & 2.595 & 0.22 & 0.067 & 0.008 & 3.7 \\
\hline 52 & Shrubland & 0.156 & 0.2 & 0.656 & 0.22 & 0.021 & 0.002 & 1.3 \\
\hline 71 & Grasslands & 0.51 & 4.316 & 2.092 & 1.953 & 0.024 & 0.033 & 8.9 \\
\hline 81 & Pasture/hay & 0.506 & 5.117 & 3.922 & 0.735 & 0.076 & 0.004 & 10.4 \\
\hline 82 & Cultivated crops & 1.142 & 24.462 & 9.712 & 2.299 & 0.209 & 0.007 & 37.8 \\
\hline 90 & Woody wetlands & 0.986 & 1.763 & 1.366 & 0.282 & 1.162 & 0.028 & 5.6 \\
\hline 95 & Herbaceous wetlands & 0.222 & 0.735 & 0.28 & 0.08 & 0.339 & 0.048 & 1.7 \\
\hline NA & Glacial domain total in soil group & 8.0 & 47.4 & 33.4 & 7.3 & 2.5 & 1.4 & -- \\
\hline
\end{tabular}

Table 3. Percentage of the glacial aquifer system by 2011 land-cover class from the National Land Cover Database dataset (Homer and others, 2015) and the Digital General Soil Map of the United States (STATSG02) hydrologic soil group (Natural Resources Conservation Service, 2015).

[The total number of active square kilometer cells in the model domain is 1,736,651; NA, not applicable; --, no data]

\begin{tabular}{|c|c|c|c|c|c|c|c|c|}
\hline \multirow[b]{2}{*}{$\begin{array}{l}\text { Land- } \\
\text { cover } \\
\text { class }\end{array}$} & \multirow[b]{2}{*}{ Description } & \multicolumn{7}{|c|}{ Percentage of domain } \\
\hline & & $\begin{array}{c}\text { Hydrologic } \\
\text { soil group } \\
\text { A }\end{array}$ & $\begin{array}{c}\text { Hydrologic } \\
\text { soil group } \\
\text { B }\end{array}$ & $\begin{array}{c}\text { Hydrologic } \\
\text { soil group } \\
\text { C }\end{array}$ & $\begin{array}{c}\text { Hydrologic } \\
\text { soil group } \\
\text { D }\end{array}$ & $\begin{array}{l}\text { Organic soil } \\
\text { group }\end{array}$ & $\begin{array}{l}\text { Open } \\
\text { water }\end{array}$ & $\begin{array}{c}\text { Glacial } \\
\text { domain total } \\
\text { land cover }\end{array}$ \\
\hline 11 & Open water & 0.262 & 1.008 & 0.492 & 0.15 & 0.064 & 1.274 & 3.3 \\
\hline 21 & Developed, open space & 0.358 & 1.468 & 0.976 & 0.164 & 0.035 & 0.005 & 3.0 \\
\hline 22 & Developed, low intensity & 0.268 & 0.977 & 0.622 & 0.117 & 0.018 & 0.003 & 2.0 \\
\hline 24 & Developed, high intensity & 0.052 & 0.142 & 0.095 & 0.015 & 0.003 & 0.001 & 0.3 \\
\hline 31 & Barren land (rock/sand/clay) & 0.032 & 0.056 & 0.056 & 0.022 & 0.006 & 0.006 & 0.2 \\
\hline 41 & Deciduous forest & 2.179 & 5.934 & 8.328 & 0.715 & 0.322 & 0.023 & 17.5 \\
\hline 42 & Evergreen forest & 0.742 & 0.461 & 1.939 & 0.308 & 0.104 & 0.015 & 3.6 \\
\hline 43 & Mixed forest & 0.385 & 0.435 & 2.513 & 0.207 & 0.063 & 0.008 & 3.6 \\
\hline 82 & Cultivated crops & 1.139 & 24.509 & 9.709 & 2.303 & 0.208 & 0.006 & 37.9 \\
\hline 90 & Woody wetlands & 0.989 & 1.77 & 1.477 & 0.306 & 1.158 & 0.024 & 5.7 \\
\hline 95 & Herbaceous wetlands & 0.231 & 0.722 & 0.294 & 0.083 & 0.347 & 0.023 & 1.7 \\
\hline NA & Glacial domain total in soil group & 8.0 & 47.4 & 33.4 & 7.3 & 2.5 & 1.4 & -- \\
\hline
\end{tabular}




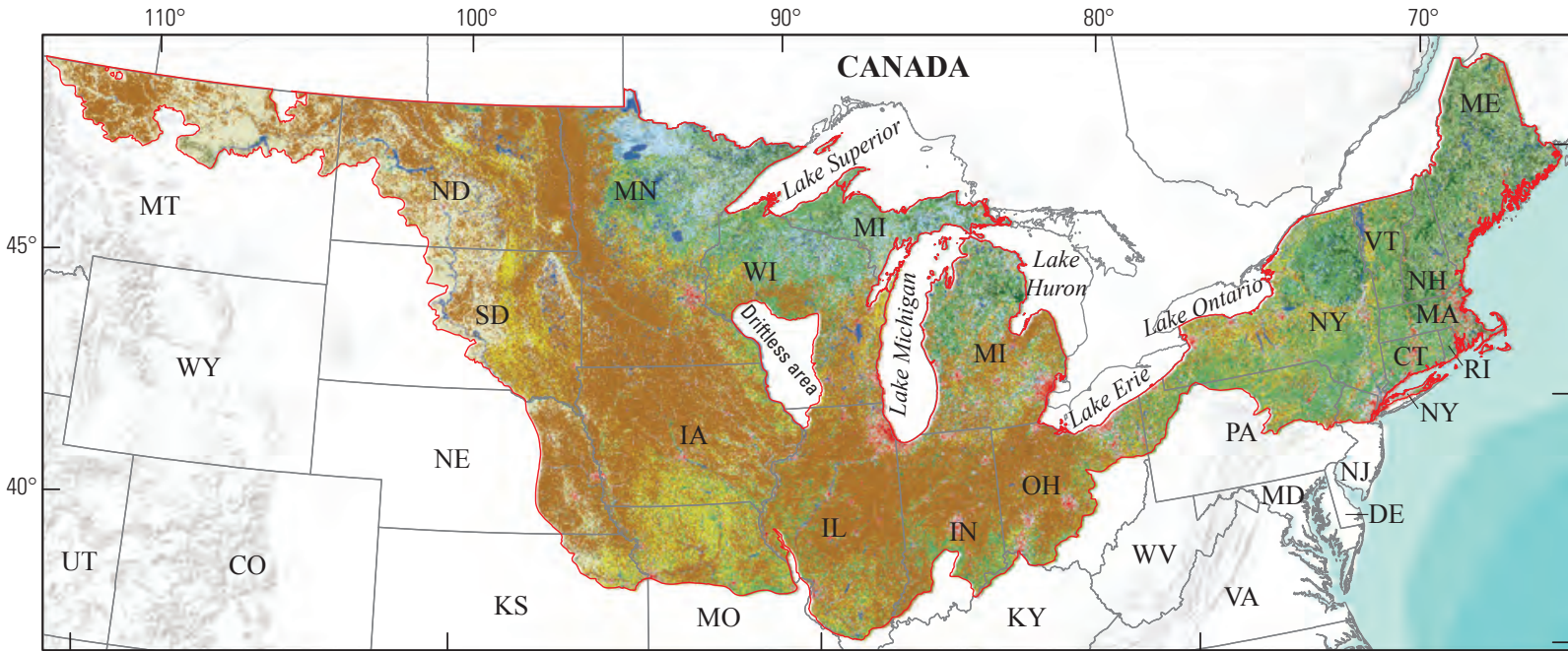

Base map image is the intellectual property of Esri and is used herein under license. Copyright (C) 2017 Esri and its licensors. All rights reserved. Base modified from Esri digital data, 1:70,000 (Esri, 2009)

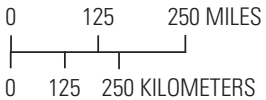

Base map of states from U.S. Geological Survey 1:2,000,000 digital data

Albers Equal-Area Conic projection, standard parallels $29^{\circ} 30^{\prime} \mathrm{N}$., and $45^{\circ} 30^{\prime} \mathrm{N}$. Central meridian $96^{\circ} 00^{\prime} \mathrm{W}$., latitude of origin $23^{\circ} 00^{\prime} \mathrm{N}$.

\section{EXPLANATION}

\begin{tabular}{|c|c|}
\hline \multicolumn{2}{|c|}{ Land cover (modified from Fry and others, 2011) } \\
\hline Open water & Mixed forest \\
\hline Developed, open space & Shrubland \\
\hline Developed, low intensity & Grasslands/herbaceous \\
\hline Developed, medium intensity & Pasture/hay \\
\hline Developed, high intensity & Row crops \\
\hline Barren land (rock/sand/clay) & Woody wetlands \\
\hline Deciduous forest & Emergent herbaceous wetlands \\
\hline Evergreen forest & \\
\hline
\end{tabular}

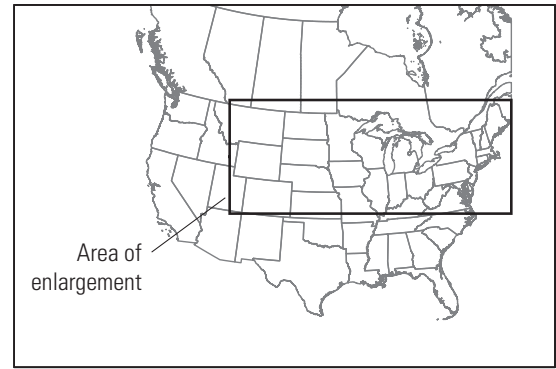

Figure 4. Land-cover classes according to the 2006 National Land Cover Database within the extent of the glacial aquifer system at a 1-kilometer resolution (Fry and others, 2011).

(Esri, 2012). Then, the grid was exported to an ASCII data grid for use in the SWB model. The following paragraphs describe the HSG classification systems used for this report as shown in figure 5 .

The Natural Resources Conservation Service (2007) provides numeric definitions and detailed descriptions of the HSG classes; only general descriptions are included here. Soils in group A are typically sandy with a high infiltration capacity and low runoff potential when thoroughly wet. In contrast, soils in group D are typically clayey with a very low infiltration capacity and high runoff potential. Group B and C soils fall between these extremes. The slope of the soil surface is not considered when assigning HSGs.

Certain wet soils are placed in group D based solely on the presence of a water table within 24 in. of the surface even though the saturated hydraulic conductivity may be favorable for water transmission. These soils are assigned to dual HSGs
(A/D, B/D, and C/D) because infiltration is limited only by a shallow water table. The first letter applies to the drained condition and the second to the undrained condition (Natural Resources Conservation Service, 2007). For the glacial SWB model, all A/D, B/D, and C/D soils were classified according to their drained condition; for example, soils of type $\mathrm{A} / \mathrm{D}$ were classified as soil type A. The Minnesota SWB model used soils classified to their drained condition because the soils commonly were in parts of the State with extensive artificial drainage (Smith and Westenbroek, 2015). Soils with the dual designations comprise about 9 percent of the active glacial SWB model domain. Most (79 percent) of these dual-group soils are in States west of Pennsylvania, and the distribution of these soils generally coincides with areas of tile drainage (Madramootoo and others, 2007); therefore, classification of these soils in their drained condition was the most representative classification for the glacial SWB model. 


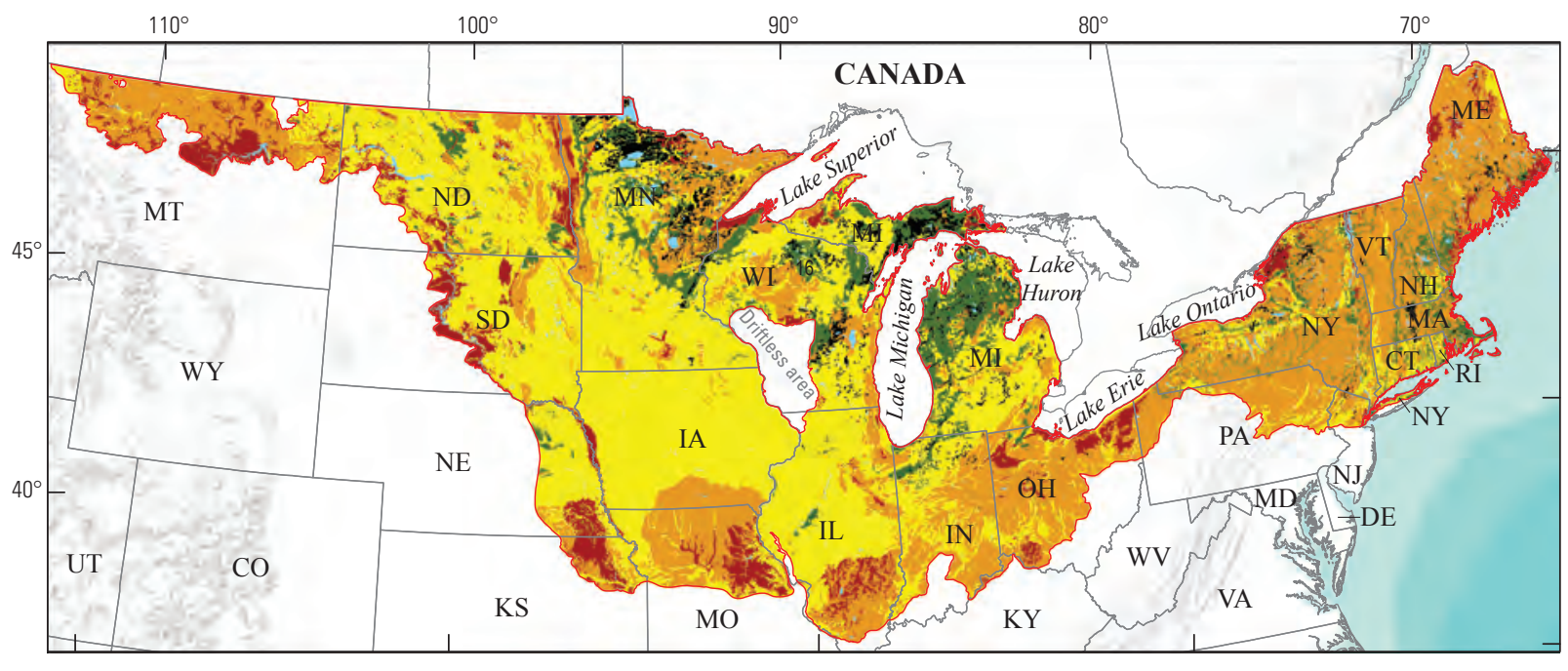

Base map image is the intellectual property of Esri and is used herein under license. Copyright (c) 2017 Esri and its licensors. All rights reserved. Base modified from Esri digital data, 1:70,000 (Esri, 2009)

$0 \quad 125 \quad 250$ MILES

Base map of states from U.S. Geological Survey 1:2,000,000 digital data

Albers Equal-Area Conic projection, standard parallels $29^{\circ} 30^{\prime} \mathrm{N}$. , and $45^{\circ} 30^{\prime} \mathrm{N}$.

Central meridian $96^{\circ} 00^{\prime} \mathrm{W}$., latitude of origin $23^{\circ} 00^{\prime} \mathrm{N}$.

\section{EXPLANATION}

$\square$ Extent of glacial Soil-Water-Balance model domain
Hydrologic soil group
Group A
Group B
Group C
Group D
Organic
Water

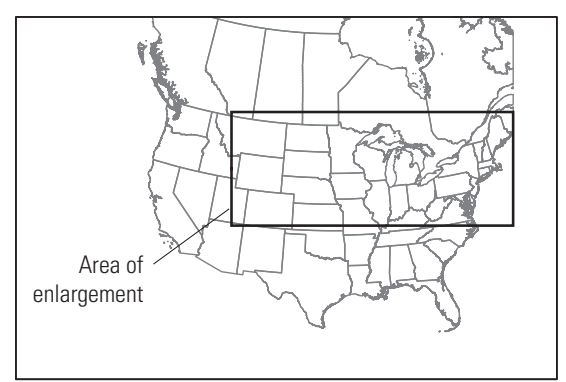

Figure 5. Hydrologic soil groups within the extent of the glacial aquifer system at a 1-kilometer resolution, based on the Digital General Soil Map of the United States (STATSG02) (Natural Resources Conservation Service, 2015; Wieczorek, 2014).

Soils with greater than 20 percent organic matter and less than 50 percent clay in the averaged STATSGO2 dataset (Michael Wieczorek, written commun., January 16, 2015) were assigned to an "organic" HSG. This classification is based on the definition from Donahue and others (1983) and methods used in the Minnesota SWB model (Smith and Westenbroek, 2015). This unique class was created because organic soils can hold more water than the same volume of a nonorganic, mineral soil (Natural Resources Conservation Service, 2007) that potentially would be underpredicted by the STATSGO2 available soil-water capacity.

An "open-water" HSG was assigned to cells that were classified as such in the STATSGO2 data. Model cells in this category produced no potential recharge because the curve numbers were set to 100 (table 4).

\section{Available Water Capacity}

The 100-m AWC grid from STATSGO2 (Michael Wieczorek, written commun., January 16, 2015) was resampled to $1-\mathrm{km}$ resolution using a bilinear interpolation protocol in Esri ArcMap 10.1 (Esri, 2012) and exported to an ASCII data grid for use in the SWB model as shown in figure 6.

The AWC input data reflect the amount of water the soil profile can hold, typically given as inches of water holding capacity per foot of soil thickness, or inches per foot. For each model cell, the AWC value is multiplied by the root-zone depth to calculate the maximum soil-water capacity, which represents the maximum amount of soil-water storage that can take place in a grid cell (fig. 2). Because root-zone depths are assigned according to land cover and HSG (table 4), the 
Table 4. Lookup table for the calibrated Soil-Water-Balance model, corresponding land cover to runoff curve number (by hydrologic soil group), maximum recharge rate (by hydrologic soil group), interception storage (growing season/dormant season), and root-zone depth (by hydrologic soil group).

[ $a$ is the intercept in equation $2 ; b$ is the slope in equation $2 ; n=0$ for open water and $n=1$ for all other land-cover types in equation 2; NA, not applicable]

\begin{tabular}{|c|c|c|c|c|c|c|c|c|c|c|c|c|c|c|}
\hline \multirow{2}{*}{$\begin{array}{l}\text { Land- } \\
\text { cover } \\
\text { class }\end{array}$} & \multirow[b]{2}{*}{ Description } & \multirow{2}{*}{$\begin{array}{c}\text { Assumed } \\
\text { impervious- } \\
\text { ness }\end{array}$} & \multicolumn{6}{|c|}{ Runoff curve number } & \multicolumn{6}{|c|}{ Maximum recharge rate (inches per day) } \\
\hline & & & $\begin{array}{c}\text { Hydrologic } \\
\text { soil group } \\
\text { A }\end{array}$ & $\begin{array}{c}\text { Hydrologic } \\
\text { soil group } \\
\text { B }\end{array}$ & $\begin{array}{c}\text { Hydrologic } \\
\text { soil group } \\
\text { C }\end{array}$ & $\begin{array}{l}\text { Hydrologic } \\
\text { soil group } \\
\text { D }\end{array}$ & $\begin{array}{c}\text { Organic } \\
\text { soil } \\
\text { group }\end{array}$ & $\begin{array}{l}\text { Open } \\
\text { water }\end{array}$ & $\begin{array}{c}\text { Hydrologic } \\
\text { soil group } \\
\text { A }\end{array}$ & $\begin{array}{c}\text { Hydrologic } \\
\text { soil group } \\
\text { B }\end{array}$ & $\begin{array}{c}\text { Hydrologic } \\
\text { soil group } \\
\text { C }\end{array}$ & $\begin{array}{c}\text { Hydrologic } \\
\text { soil group } \\
\text { D }\end{array}$ & $\begin{array}{c}\text { Organic } \\
\text { soil } \\
\text { group }\end{array}$ & $\begin{array}{l}\text { Open } \\
\text { water }\end{array}$ \\
\hline 11 & Open water & NA & 100.0 & 100.0 & 100.0 & 100.0 & 100.0 & 100.0 & 0.0 & 0.0 & 0.0 & 0.0 & 0.0 & 0.0 \\
\hline 21 & $\begin{array}{l}\text { Developed, open } \\
\text { space }\end{array}$ & NA & 48.9 & 60.9 & 71.3 & 79.5 & 60.9 & 100.0 & 4.5 & 0.8 & 0.3 & 0.2 & 2.5 & 0.0 \\
\hline 22 & $\begin{array}{l}\text { Developed, low } \\
\text { intensity }\end{array}$ & 30 percent & 61.2 & 73.9 & 82.9 & 88.6 & 73.9 & 100.0 & 4.4 & 0.8 & 0.3 & 0.2 & 2.3 & 0.0 \\
\hline 23 & $\begin{array}{l}\text { Developed, medium } \\
\text { intensity }\end{array}$ & 60 percent & 76.3 & 86.0 & 91.2 & 93.8 & 86.0 & 100.0 & 4.0 & 0.9 & 0.5 & 0.4 & 2.5 & 0.0 \\
\hline 24 & $\begin{array}{l}\text { Developed, high } \\
\text { intensity }\end{array}$ & 90 percent & 88.7 & 93.2 & 95.0 & 95.6 & 93.2 & 100.0 & 3.3 & 0.9 & 0.4 & 0.5 & 2.0 & 0.0 \\
\hline 31 & $\begin{array}{l}\text { Barren land (rock/ } \\
\text { sand/clay) }\end{array}$ & NA & 61.2 & 73.9 & 82.9 & 88.6 & 73.9 & 100.0 & 5.2 & 1.0 & 0.5 & 0.5 & 2.8 & 0.0 \\
\hline 41 & Deciduous forest & NA & 42.0 & 57.8 & 67.1 & 71.3 & 57.8 & 100.0 & 4.9 & 1.4 & 0.5 & 0.2 & 2.8 & 0.0 \\
\hline 42 & Evergreen forest & NA & 54.0 & 70.3 & 79.0 & 82.8 & 70.3 & 100.0 & 5.7 & 2.4 & 0.8 & 0.5 & 3.6 & 0.0 \\
\hline 43 & Mixed forest & NA & 47.8 & 64.0 & 73.0 & 77.1 & 64.0 & 100.0 & 5.3 & 2.3 & 0.7 & 0.5 & 2.8 & 0.0 \\
\hline 52 & Shrubland & NA & 53.9 & 68.9 & 76.7 & 80.1 & 68.9 & 100.0 & 5.4 & 1.5 & 0.5 & 0.2 & 2.2 & 0.0 \\
\hline 71 & Grasslands & NA & 48.3 & 64.7 & 74.0 & 78.1 & 64.7 & 100.0 & 4.0 & 0.4 & 0.1 & 0.1 & 3.4 & 0.0 \\
\hline 81 & Pasture/hay & NA & 65.5 & 83.6 & 93.1 & 97.2 & 83.6 & 100.0 & 3.7 & 0.6 & 0.2 & 0.1 & 1.7 & 0.0 \\
\hline 82 & Cultivated crops & NA & 21.8 & 40.6 & 59.4 & 71.5 & 40.6 & 100.0 & 4.0 & 0.4 & 0.1 & 0.1 & 1.4 & 0.0 \\
\hline 90 & Woody wetlands & NA & 61.7 & 65.2 & 66.6 & 67.1 & 65.2 & 100.0 & 5.1 & 1.7 & 0.6 & 0.3 & 2.6 & 0.0 \\
\hline 95 & Herbaceous wetlands & NA & 61.7 & 65.2 & 66.6 & 67.1 & 65.2 & 100.0 & 4.7 & 0.9 & 0.4 & 0.4 & 1.9 & 0.0 \\
\hline
\end{tabular}


Table 4. Lookup table for the calibrated Soil-Water-Balance model, corresponding land cover to runoff curve number (by hydrologic soil group), maximum recharge rate (by hydrologic soil group), interception storage (growing season/dormant season), and root-zone depth (by hydrologic soil group).-Continued

[ $a$ is the intercept in equation $2 ; b$ is the slope in equation $2 ; n=0$ for open water and $n=1$ for all other land-cover types in equation 2; NA, not applicable]

\begin{tabular}{|c|c|c|c|c|c|c|c|c|c|c|c|c|c|c|}
\hline \multirow{2}{*}{$\begin{array}{l}\text { Land- } \\
\text { cover } \\
\text { class }\end{array}$} & \multirow[b]{2}{*}{ Description } & \multirow{2}{*}{$\begin{array}{c}\text { Assumed } \\
\text { impervious- } \\
\text { ness }\end{array}$} & \multicolumn{3}{|c|}{$\begin{array}{l}\text { Growing season } \\
\text { interception }\end{array}$} & \multicolumn{3}{|c|}{$\begin{array}{l}\text { Dormant season } \\
\text { interception }\end{array}$} & \multicolumn{6}{|c|}{$\begin{array}{l}\text { Root-zone depth } \\
\text { (feet) }\end{array}$} \\
\hline & & & a & $\boldsymbol{b}$ & $n$ & $a$ & $\boldsymbol{b}$ & $n$ & $\begin{array}{c}\text { Hydrologic } \\
\text { soil group } \\
\text { A }\end{array}$ & $\begin{array}{c}\text { Hydrologic } \\
\text { soil group } \\
\text { B }\end{array}$ & $\begin{array}{l}\text { Hydrologic } \\
\text { soil group } \\
\text { C }\end{array}$ & $\begin{array}{c}\text { Hydrologic } \\
\text { soil group } \\
\text { D }\end{array}$ & $\begin{array}{l}\text { Organic } \\
\text { soil group }\end{array}$ & $\begin{array}{l}\text { Open } \\
\text { water }\end{array}$ \\
\hline 11 & Open water & NA & 0.0000 & 0.0000 & 0 & 0.0000 & 0.0000 & 0 & 0.00 & 0.00 & 0.00 & 0.00 & 0.00 & 0.00 \\
\hline 21 & Developed, open space & NA & 0.0013 & 0.0030 & 1 & 0.0013 & 0.0020 & 1 & 2.11 & 2.33 & 1.93 & 1.71 & 2.33 & 0.00 \\
\hline 22 & Developed, low intensity & 30 percent & 0.0012 & 0.0030 & 1 & 0.0012 & 0.0020 & 1 & 1.60 & 1.82 & 1.42 & 1.20 & 1.82 & 0.00 \\
\hline 23 & $\begin{array}{l}\text { Developed, medium } \\
\text { intensity }\end{array}$ & 60 percent & 0.0010 & 0.0020 & 1 & 0.0010 & 0.0020 & 1 & 1.16 & 1.38 & 0.98 & 0.76 & 1.38 & 0.00 \\
\hline 24 & Developed, high intensity & 90 percent & 0.0009 & 0.0020 & 1 & 0.0009 & 0.0020 & 1 & 0.78 & 1.00 & 0.60 & 0.38 & 1.00 & 0.00 \\
\hline 31 & $\begin{array}{l}\text { Barren land (rock/sand/ } \\
\text { clay) }\end{array}$ & NA & 0.0010 & 0.0030 & 1 & 0.0010 & 0.0020 & 1 & 1.60 & 1.82 & 1.42 & 1.20 & 1.82 & 0.00 \\
\hline 41 & Deciduous forest & NA & 0.0014 & 0.0290 & 1 & 0.0014 & 0.0130 & 1 & 4.35 & 4.15 & 4.06 & 4.15 & 4.15 & 0.00 \\
\hline 42 & Evergreen forest & NA & 0.0017 & 0.0970 & 1 & 0.0017 & 0.0590 & 1 & 5.20 & 4.69 & 4.44 & 4.69 & 4.69 & 0.00 \\
\hline 43 & Mixed forest & NA & 0.0016 & 0.0630 & 1 & 0.0016 & 0.0630 & 1 & 4.77 & 4.42 & 4.25 & 4.42 & 4.42 & 0.00 \\
\hline 52 & Shrubland & NA & 0.0013 & 0.0080 & 1 & 0.0013 & 0.0050 & 1 & 3.25 & 2.53 & 3.25 & 3.81 & 2.53 & 0.00 \\
\hline 71 & Grasslands & NA & 0.0008 & 0.0070 & 1 & 0.0008 & 0.0050 & 1 & 2.68 & 2.35 & 2.68 & 2.94 & 2.35 & 0.00 \\
\hline 81 & Pasture/hay & NA & 0.0013 & 0.0080 & 1 & 0.0013 & 0.0050 & 1 & 4.01 & 3.29 & 4.01 & 4.57 & 3.29 & 0.00 \\
\hline 82 & Cultivated crops & NA & 0.0010 & 0.0100 & 1 & 0.0010 & 0.0020 & 1 & 2.39 & 2.36 & 2.28 & 2.36 & 2.36 & 0.00 \\
\hline 90 & Woody wetlands & NA & 0.0014 & 0.0230 & 1 & 0.0014 & 0.0160 & 1 & 2.39 & 2.39 & 2.39 & 2.39 & 2.39 & 0.00 \\
\hline 95 & Herbaceous wetlands & NA & 0.0014 & 0.0230 & 1 & 0.0014 & 0.0160 & 1 & 1.48 & 1.48 & 1.48 & 1.48 & 1.48 & 0.00 \\
\hline
\end{tabular}




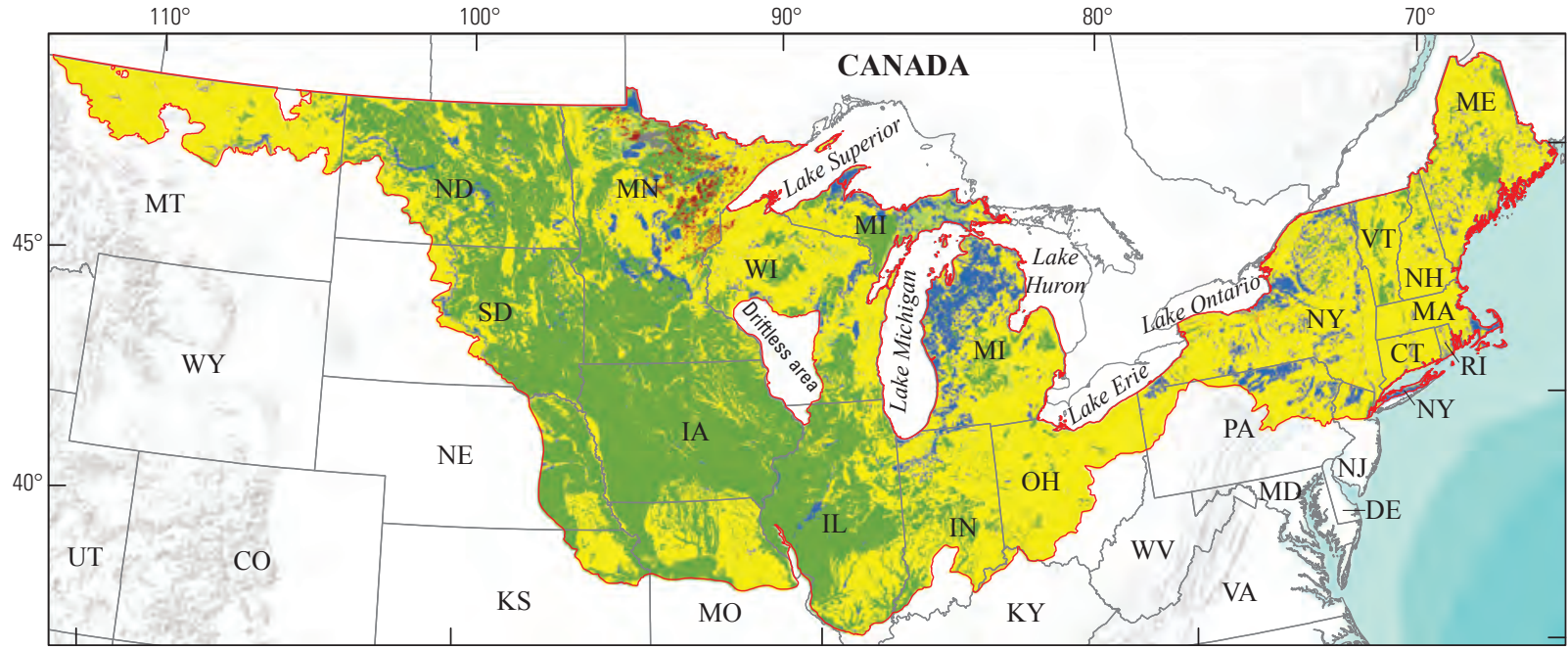

Base map image is the intellectual property of Esri and is used herein under license. Copyright (C) 2017 Esri and its licensors. All rights reserved. Base modified from Esr digital data, 1:70,000 (Esri, 2009)

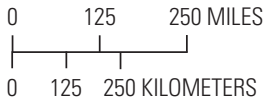

Base map of states from U.S. Geological Survey 1:2,000,000 digital data

Albers Equal-Area Conic projection, standard parallels $29^{\circ} 30^{\prime} \mathrm{N}$., and $45^{\circ} 30^{\prime} \mathrm{N}$

Central meridian $96^{\circ} 00^{\prime} \mathrm{W}$., latitude of origin $23^{\circ} 00^{\prime} \mathrm{N}$.

EXPLANATION

\begin{tabular}{|l}
$\square$ Extent of glacial Soil-Water-Balance model domain \\
Available soil-water capacity, in \\
inches of water per foot of soil \\
Less than 1 \\
1.01 to 2.00 \\
2.01 to 3.00 \\
3.01 to 4.00 \\
4.01 to 5.00 \\
5.01 to 6.00 \\
6.01 to 7.00
\end{tabular}

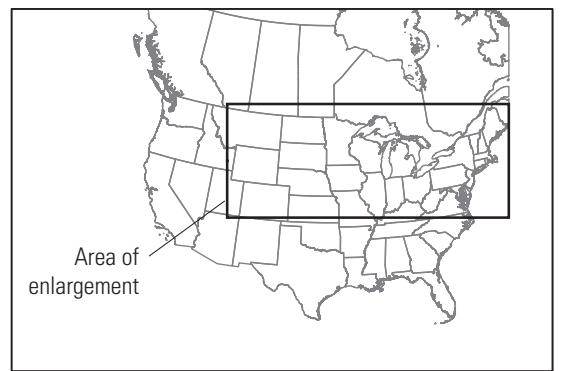

Figure 6. Available soil-water capacity within the extent of the glacial aquifer system at a 1-kilometer resolution, based on the Digital General Soil Map of the United States (STATSG02) (Natural Resources Conservation Service, 2015; Wieczorek, 2014).

maximum soil-water capacity incorporates land-cover and soils information. Water added to the soil column in excess of the maximum soil-water capacity value becomes recharge (fig. 2).

\section{Maximum Recharge Rate}

The maximum daily recharge rate is specified for each combination of land cover and HSG in the lookup table. For the glacial aquifer SWB model, maximum daily recharge rates for each land-cover HSG combination were estimated by zonal statistics of hydraulic conductivities from the STATSGO2 dataset (Michael Wieczorek, written commun., January 16, 2015). The method assumes that saturated hydraulic conductivity can be used as a surrogate of maximum recharge rates amongst the HSG and land-cover class combinations. Pedotransfer functions from Saxton and Rawls (2006) were used to estimate hydraulic conductivities from the percentage of clay, sand, and organic matter given in the 100-m resolution STATSGO2 dataset. Hydraulic conductivities were calculated for each map unit polygon in the active glacial SWB model domain. These hydraulic conductivities then were resampled to a $1-\mathrm{km}$ grid resolution using bilinear interpolation. The mean hydraulic conductivity of each land-cover HSG combination represented the maximum recharge rate for each combination.

\section{Lookup Tables and Control File}

The SWB model uses two lookup tables to assign model cell properties related to soils and land cover: (1) the soil and land-cover parameter lookup table (table 4), and (2) the extended Thornthwaite-Mather soil-water retention table (Thornthwaite and Mather, 1957). The soil and landcover parameter lookup table (table 4) assigns parameters 
describing the processes of interception, runoff, ET, infiltration, and recharge to each of the 90 unique combinations of 15 land-cover classes and 6 soil classes (4 HSG classes, organic soil class, and open-water class) in the glacial aquifer system model domain. Specifically, table 4 contains calibrated values of dimensionless curve numbers (Cronshey and others, 1986), maximum recharge rates (in inches per day), root-zone depths (in feet), and plant-canopy interception parameters for growing and dormant seasons. The extended Thornthwaite-Mather soil-water retention table describes the ability of different soils to hold water (Thornthwaite and Mather, 1957). This table assists in the calculation of soil-moisture adjustments during periods of unsatisfied potential ET. Adjustments were not made to the extended Thornthwaite-Mather soil-water retention table during model calibration.

The control file used to run the glacial SWB model is in the model archive (Trost, 2018); a few specifications in the glacial SWB model control file are noted here. The control file handles all the user-defined options for an individual SWB simulation, such as the growing season length, model domain grid definition, the routing method, location of input files, and control over the SWB output. Overland-flow routing (also known as runoff routing) was turned off.

The Hargreaves-Samani method (1985) was used to estimate potential ET and required the daily maximum and minimum temperatures from the Daymet dataset (Thornton and others, 2014). In the SWB model, initial values for abstraction can be set by multiplying the maximum soil-moisture holding capacity by either 0.2 or 0.05 . For the glacial SWB model, the smaller initial abstraction was used and resulted in more runoff for smaller precipitation events, which has been recognized as more appropriate for multiyear simulations (Woodward and others, 2003).

The SWB model code version used to simulate potential recharge for the glacial aquifer system used an interception algorithm based on Horton (1919) that is different from the "bucket" interception method used in previously published SWB models (for example, Feinstein and others, 2010; Westenbroek and others, 2010; Masterson and others, 2013; Smith and Westenbroek, 2015). The "bucket" interception method only allows for a single interception value regardless of the total storm volume, whereas the Horton interception algorithm produces a series of "working formulas" that relate the daily or storm total rainfall to the amount of interception by vegetation. These working formulas are typically simple linear models with intercepts and slope terms. Parameters for the Horton interception algorithm required inputs in the lookup table that varied by land-cover type as in previous SWB models; however, the parameters in the lookup table (table 4) now were used by SWB in the following equation:

$$
I_{L s}=a_{L}+b_{L s} \times P^{n}
$$

where

$I \quad$ is the daily interception for land cover $L$ during season $s$ (growing or dormant), in inches;

$a_{L} \quad$ is the intercept for land cover $L$, in inches;

$b_{L s} \quad$ is the slope for land cover $L$ during season $s$ (growing or dormant), unitless;

$P \quad$ is the daily precipitation total, in inches; and

$n \quad$ is 0 for open-water land-cover types and 1 for all nonopen-water land-cover types.

Growing season start and end dates differ greatly across the glacial SWB model domain. The SWB model code version used to simulate potential recharge for the glacial aquifer system had two options for switching between the growing season and dormant season: fixed Julian start and end dates, or a dynamic start and end for each model cell based on growing degree-day calculations and a killing frost temperature from meteorological data. The dynamic option was used in the glacial SWB model, which means that for each year in each model cell, the growing season began when growing degree days accumulated above the threshold specified in the control file (GROWING_SEASON_STARTING_GDD). Growing degree days represent an accumulation of heat units above a base temperature below which the process of interest does not progress (McMaster and Wilhelm, 1997). The growing season was terminated in each model cell when daily meteorological data for that cell fell below the killing frost temperature specified in the control file (GROWING_SEASON_KILLING_FROST).

\section{Initial Conditions}

For individual model calibration basins, spatially distributed initial conditions for soil-water content (SWC), CFGI, and snow cover (SC) were generated by completing a 1-year simulation using initial, uncalibrated parameter values. For basins with records that began in 1980, initial SWC, CFGI, and $\mathrm{SC}$ conditions were determined from a simulation of the year 1980 because gridded meteorological data were not available for years before 1980. For basins with streamflow records starting after 1980, initial SWC, CFGI, and SC were determined from a simulation beginning 1 year before the streamflow record. For the 1980-2011 model domain run, SWC, CFGI, and SC outputs from a "warm up" simulation of the year 1980 were used as initial conditions.

\section{Model Calibration and Evaluation Methods}

Model calibration is an iterative process that investigates the effects that model parameters have on the ability of a model to reproduce a set of measured observations. The SWB model was calibrated to base-flow observations from 39 basins across the glacial aquifer system study area. A total 
of 62 model parameters were calibrated. Calibrated parameter values were compared to values from previously published SWB models that overlapped parts of the glacial SWB model domain (Aurand, 2013; Feinstein and others, 2010; McCoy and others, 2015; Smith and Westenbroek, 2015; Westenbroek and others, 2010). The fit of the SWB-simulated potential recharge to observed recharge (derived from base flow for 39 calibration basins) was evaluated using graphical analysis and error evaluation statistics. Observed recharge rates from a second set of 38 "verification" basins not used for model calibration were used as an independent verification of the ability of the SWB model to simulate potential recharge across the model domain.

\section{Calibration Targets}

The glacial SWB model was calibrated to base flow calculated with the HYSEP local minimum method in 39 basins (Sloto and Crouse, 1996). Recharge was determined by summing the quantity of base flow for each year and dividing that total by the area of each respective basin. The resulting summary dataset is given in inches of recharge per year (table 5, available for download at https://doi.org/10.3133/ sir20185080).

\section{Basin Selection}

Basins selected for calibration met three general criteria: (1) the basins exhibited hydrologic conditions appropriate for hydrograph separation (for example, were not regulated); (2) the basins represented the model domain spatially (fig. 1); and (3) the basins represented the model domain temporally in that they had at least 15 years of continuous streamflow data between 1980 and 2011 (table 5). The following paragraphs describe each of these characteristics (hydrologic, spatial, temporal) in more detail.

Calibration basins were selected using criteria listed in the Geospatial Attributes of Gages for Evaluating Streamflow, version II (GAGES II) database (Falcone, 2011). The GAGES II dataset consists of gages that have had either at least 20 complete years of streamflow record since 1950 or are currently active as of water year 2009 and whose watersheds lie within the United States (Falcone, 2011). A water year is the period from October 1 to September 30 and is designated by the year in which it ends; for example, water year 2009 was from October 1, 2008, to September 30, 2009. All 39 calibration basins were identified as "reference" sites in GAGES II, and 34 basins were part of the higher quality 2009 Hydroclimatic Data Network.

Reference gages in the GAGES II dataset met the following three primary criteria (Lins, 2012): (1) hydrologic disturbance of the watershed was less than at least 75 percent of all other gaged watersheds in its region; (2) the USGS Annual Water Data Reports did not identify the presence of "regulated" streamflows, although some sites considered to have minor modifications were retained; and, (3) the watershed passed a visual screen using satellite imagery (typically Google Earth) of the watershed for the presence of human activities that indicated flow diversions, groundwater withdrawal, and other factors known to affect natural streamflows.

Several additional criteria listed in GAGES II were used to identify candidate calibration basins: (1) major dams were not in the watershed; (2) watershed sizes were between 39 square miles $\left(\mathrm{mi}^{2} ; 100\right.$ square kilometers $\left.\left[\mathrm{km}^{2}\right]\right)$ and $734 \mathrm{mi}^{2}\left(1,900 \mathrm{~km}^{2}\right)$; (3) BFI averages, as determined by Wolock (2003b), were between 10 percent and 90 percent of total streamflow; (4) less than 40 percent of precipitation fell as snow; (5) there were fewer than 100 days of 0 cubic feet per second $\left(\mathrm{ft}^{3} / \mathrm{s}\right)$ streamflow between 1980 and 2011, except for two basins in North Dakota; (6) less than 25 percent of the basin area was classified as woody wetlands or emergent wetlands; (7) the nearest major National Pollutant Discharge Elimination System discharge point was at least 2 mi away (33 basins had no National Pollutant Discharge Elimination System discharge point); and (8) freshwater withdrawals were less than 48 million gallons per $\mathrm{mi}^{2}$ ( 70 megaliters per year per $\mathrm{km}^{2}$ ) according to 1995 to 2000 county-level estimates. Within the glacial domain, 77 basins met all the above criteria.

The 77 basins were mapped, and a spatially distributed subset of 39 basins was selected for model calibration. Computation times limited the number of calibration basins; the other 38 basins were used to verify that the model simulated reasonable results for areas not used for calibration. Some basins were clustered and adjacent to one another; in these cases, only one basin per cluster was included for calibration. The 39 basins were selected from the 77 basins through an iterative process used to minimize the differences in the relative frequency of the 2006 NLCD land-cover classes and STATSGO2 HSGs between the calibration basins and overall active model domain. The resulting 39 basins compared reasonably well with the overall domain distributions (tables 6,7). The cumulative area of the calibration basins was $24,465 \mathrm{~km}^{2}$, about 1.4 percent of the total active model domain area. The distributions of land-cover classes in the calibration basins were all within 5 percent of the domain distribution (table 6). The HSG C soils were overrepresented in the calibration dataset by 8.9 percent; otherwise, all other soil types were within 5 percent of the domain distribution (table 7).

Streamflow records from the calibration basins represented the temporal variability during 1980-2011. Of the 39 calibration basins, 3 had 15 to 20 years of daily streamflow data, 2 had 21 to 30 years of daily streamflow data, and 34 basins had more than 30 years of daily streamflow data (table 5).

\section{Base-Flow (Recharge) Observations and Weights}

Five methods of hydrograph separation were investigated for use as calibration targets: PART (Rutledge, 1998), HYSEP fixed interval, HYSEP sliding interval, HYSEP local minimum (Sloto and Crouse, 1996), and BFI (Gustard and others, 1992). Of these five methods, the HYSEP local minimum method 
Table 6. Distribution of land cover in the calibration basins and for the glacial Soil-Water-Balance model domain, based on the 2006 National Land Cover Database (Fry and others, 2011).

\begin{tabular}{llccc}
\hline \multirow{2}{*}{ Land-cover class } & \multicolumn{1}{c}{ Description } & $\begin{array}{c}\text { Land-cover distribution, in percent } \\
\text { 39 calibration watersheds } \\
\text { (table 5) }\end{array}$ & $\begin{array}{c}\text { Entire glacial } \\
\text { model domain }\end{array}$ & $\begin{array}{c}\text { Difference, in percent } \\
\text { between calibration } \\
\text { watersheds and glacial } \\
\text { model domain }\end{array}$ \\
\cline { 2 - 5 } & & 1.11 & 3.06 & -1.95 \\
21 & Open water & 1.75 & 3.00 & -1.26 \\
22 & Developed, open space & 0.59 & 2.02 & -1.43 \\
23 & Developed, low intensity & 0.11 & 0.75 & -0.65 \\
24 & Developed, medium intensity & 0.02 & 0.29 & -0.27 \\
31 & Developed, high intensity & 0.02 & 0.17 & -0.15 \\
41 & Barren land (rock/sand/clay) & 21.16 & 17.68 & 3.49 \\
42 & Deciduous forest & 3.53 & 3.62 & -0.09 \\
43 & Evergreen forest & 5.13 & 3.75 & 1.39 \\
52 & Mixed forest & 1.21 & 1.26 & -0.04 \\
71 & Shrubland & 4.44 & 8.93 & -4.49 \\
81 & Grasslands & 12.02 & 10.36 & 1.66 \\
82 & Pasture/hay & 42.15 & 37.83 & 4.31 \\
90 & Cultivated crops & 5.11 & 5.59 & -0.48 \\
95 & Woody wetlands & 1.66 & 1.70 & -0.04 \\
\hline
\end{tabular}

Table 7. Distribution of hydrologic soil groups in the calibration basins and for the glacial Soil-Water-Balance model domain, based on the STATSGO2 soil database (Natural Resources Conservation Service, 2015).

\begin{tabular}{|c|c|c|c|}
\hline \multirow[b]{2}{*}{$\begin{array}{l}\text { Hydrologic } \\
\text { soil group }\end{array}$} & \multicolumn{2}{|c|}{$\begin{array}{l}\text { Hydrologic soil group distribution, } \\
\text { in percent }\end{array}$} & \multirow{2}{*}{$\begin{array}{c}\text { Difference, } \\
\text { in percent } \\
\text { between } \\
\text { calibration } \\
\text { watersheds and } \\
\text { glacial model } \\
\text { domain }\end{array}$} \\
\hline & $\begin{array}{c}39 \text { calibration } \\
\text { watersheds } \\
\text { (table 5) }\end{array}$ & $\begin{array}{l}\text { Entire glacial } \\
\text { model domain }\end{array}$ & \\
\hline A & 7.5 & 8.0 & -0.4 \\
\hline B & 44.2 & 47.4 & -3.2 \\
\hline $\mathrm{C}$ & 42.3 & 33.4 & 8.9 \\
\hline $\mathrm{D}$ & 4.8 & 7.3 & -2.5 \\
\hline Organic & 1.1 & 2.5 & -1.4 \\
\hline Open water & 0.0 & 1.4 & -1.4 \\
\hline
\end{tabular}

was selected because it consistently produced results between the higher predictions of PART and HYSEP fixed and sliding interval and the lower estimates yielded by the BFI method (table 5). A streamflow hydrograph and the separation of runoff from base flow, as determined by three different methods, PART, HYSEP local minimum, and BFI, are shown in figure 7. The PART method (green line) typically was higher than the HYSEP local minimum method (red line) and the BFI method (blue dashed line), thus a higher proportion of the total streamflow was classified as base flow with the PART method as compared to the other two methods (fig. 7).
The five hydrograph separation methods were applied to daily streamflow values using the package DVstats in $\mathrm{R}$ version 3.1.2 (R Development Core Team, 2014). Recharge was determined by summing the quantity of base flow for each year and dividing that total by the area of each respective basin. The resulting summary dataset is given in inches of recharge per year (table 5). The following paragraphs use the term "base flow," which, in this report, is considered equivalent to "recharge over the basin area" for the calibration of the SWB model.

Three base-flow temporal data aggregations were used for model calibration: annual total base flow for each year of complete flow data, annual total base-flow duration deciles (10 deciles per basin, 10 percent through 100 percent), and the mean of all annual total base flows (mean annual) during 1980-2011. The calibration observation dataset consisted of 1,191 annual total base-flow observations, 340 base-flow decile observations, and 39 mean annual base-flow observations. Base-flow deciles only were computed for the 34 basins with a complete 32 -year record. The three data aggregations provided information during calibration about mean annual recharge, variability in annual recharge rates, and the cumulative frequency distribution of annual recharge rates; therefore, the glacial SWB model is appropriate for examining mean annual potential recharge and temporal variability in potential recharge.

Recharge observations used for model calibration were computed as follows. Daily streamflow data were downloaded from the USGS National Water Information System (U.S. Geological Survey, 2015) for each calibration station 


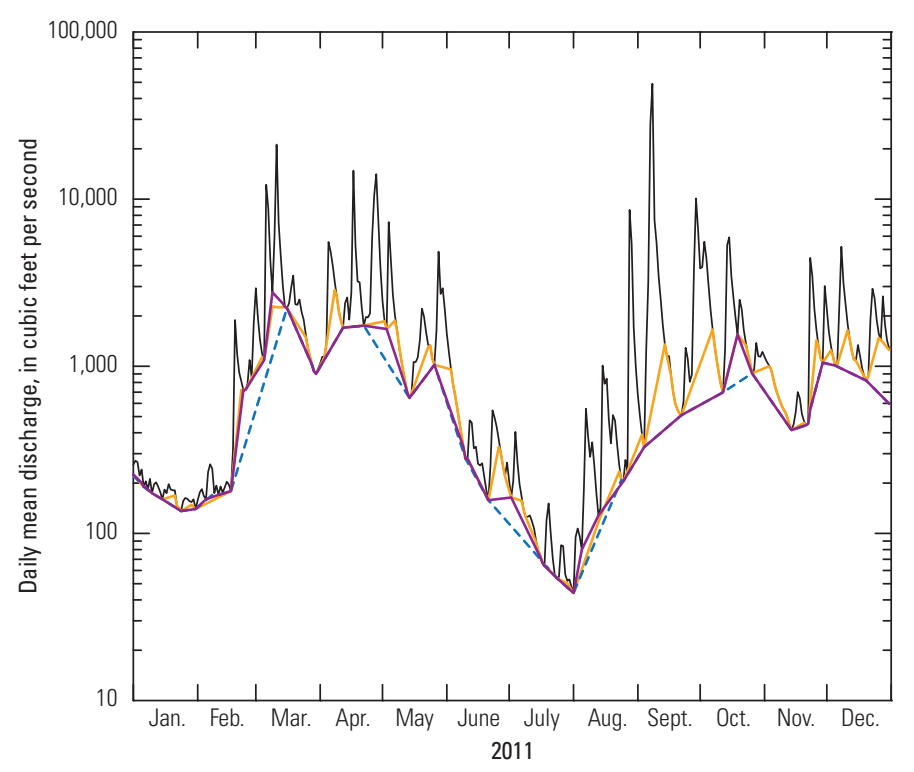

EXPLANATION

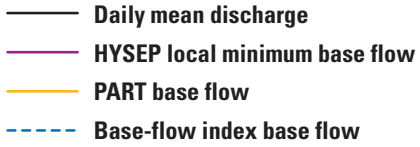

Figure 7. Example stream hydrograph and base flow from three hydrograph separation techniques, HYSEP local minimum (Sloto and Crouse, 1996), PART (Rutledge, 1998), and base-flow index (Gustard and others, 1992) for U.S. Geological Survey streamgage 01552000, Loyalsock Creek at Loyalsockville, Pennsylvania (map number 12 on fig. 1).

listed in table 5. The Time-Series Processor, TSPROC (Westenbroek and others, 2012), was used on the daily streamflow data to screen out periods with no streamflow data, run the HYSEP local minimum hydrograph separation technique, aggregate daily base flow to annual base-flow totals, compute the annual base-flow duration deciles, and determine the longterm mean base flow. The final processing step implemented by TSPROC was dividing the volumetric outputs by basin area to produce recharge in inches per year.

Weights were assigned to each of the base-flow observations used for evaluating model fit; observations from different "observation groups" (basins, in this case) can be weighted such that each group contributes nearly equally to the objective function at the start of the calibration exercise. The objective function is the sum of the weighted squared differences between simulated potential recharge and measured recharge (base-flow) values in inches per year over the basin. The weights were assigned so that the initial combined total sum of squares from annual, decile, and mean annual observations were nearly equal among basins. Within each basin, the mean annual observations were weighted highest, followed by the base-flow decile observations, followed by the annual base-flow total observations. For the five basins for which deciles were not computed, the weights assigned to the annual observations were increased relative to the weight assigned to the mean annual value so that temporal variability in the base flow of these basins still was represented adequately during the calibration process.

\section{Parameter Estimation}

A total of 62 parameters were adjusted during calibration. An additional 16 fixed parameters were not adjusted during calibration but were necessary for computing final parameter values listed in the lookup table (table 4) also are included in table 8 (available for download at https://doi. org/10.3133/sir20185080). Of the 62 adjustable parameters, 5 were "global" parameters that affected recharge computations in every active model cell and 57 were parameters applied to specific combinations of HSG and land cover according to the lookup table (table 4).

Parameters were adjusted to improve the match between the estimated potential recharge simulated by the SWB model and the recharge determined from hydrograph separation. Previously published SWB recharge models (Feinstein and others, 2010; Westenbroek and others, 2010; Aurand, 2013; McCoy and others, 2015; Smith and Westenbroek, 2015) were the basis for the initial values of parameters and the ranges of possible parameter values tested during calibration.

The five "global" parameters that were adjusted during the calibration affected potential recharge computations in every active model cell. Two parameters, CFGI_LO and CFGI_MULT, set the minimum and maximum thresholds for the CFGI. The CFGI is used to vary curve numbers between frozen and thawed soil conditions (Molnau and Bissell, 1983; Westenbroek and others, 2010). The growing season length was controlled by two parameters. The first parameter (GDD_STR) specified the minimum accumulation of growing degree days to trigger the start of the growing season. The second parameter (GDD_TMN) specified the killing frost temperature that ended the growing season, in degrees Celsius. The final global parameter (AMAXINF) represented the maximum recharge rate, in inches per day, for HSG A with deciduous forest land cover (table 4). This parameter was included in the global parameter group because the maximum recharge rates for all other soil and land-cover combinations were derived from this value (table 4). The 57 nonglobal parameters that were calibrated included 14 parameters for deriving runoff curve numbers, 16 parameters for deriving root-zone depths, 23 parameters for deriving values to use in the Horton interception algorithm, and 4 parameters to calculate the maximum recharge rate in HSG soils B, C, D, and organic soils (table 8).

Similar to Smith and Westenbroek (2015), predefined relations were used to calculate parameters from parameters adjusted during calibration; for example, within deciduous forest land cover, runoff curve numbers for HSGs A, B, C, and organic soils were calculated from the calibrated value of HSG D. By using a preprocessor (par2par; Doherty 2010), 
only 57 nonglobal parameters were varied directly, but all the 384 parameters in table 4 potentially could vary in successive model iterations according to the relations specified in the preprocessor. The following paragraphs describe the relations between parameters defined in the preprocessor.

Groups of runoff curve numbers for different land covers were optimized in the calibration process to improve the accuracy of the simulated potential recharge compared to measured values throughout the study area. Similar to Smith and Westenbroek (2015), relations between curve numbers within land-cover classes were established to ensure an appropriate progression of curve numbers from A through D. Curve number values from previously published SWB models (Aurand, 2013; Metropolitan Council Environmental Services, 2013; Smith and Westenbroek, 2015; Westenbroek and others, 2010) were used to develop the logistic relation (eq. 3) between curve numbers within each land-cover class. Additionally, tables $2.2 A-D$ from Cronshey and others (1986) were referenced for guidance on appropriate curve number values for different land-cover types. The logistic equation is an exponential function that can be used to model relations approaching an asymptotic theoretical maximum value.

Runoff curve numbers are derived from an empirical relation, where values of curve numbers for a specific landuse type approach a maximum value as soils transition the spectrum from sand (HSG A) to clay (HSG D). Generally, curve numbers increase across this spectrum of soils and the incremental change in successive curve numbers diminishes as soils transition from sand to clay. The exponential logistic function was selected for modelling and constraining curve number groups for the SWB model because of the ability to generate a variety of different curves with the modification of only three variables. Base values for each of the three logistic equation parameters for each land use were determined by fitting the mean of previously published SWB models for that land use. Ranges of these parameters were determined such that their adjustment could accommodate most of the range observed in previously published SWB models. Runoff curve numbers for HSG A, B, C, and organic soils were derived from the HSG D runoff curve number for each land cover according to the following logistic equation:

$$
C N_{L_{i}}=\frac{C N_{L_{D}}}{1+e^{\left(-a_{g}^{*}\left(b_{i}-c_{g}\right)\right)}}
$$

where

$$
\begin{aligned}
C N_{L_{i}} & \text { is the runoff curve number for a soil type } \\
& \text { (HSG A, B, C, D, or organic) for each land } \\
& \text { cover } L ; \\
C N_{L_{D}} & \text { is the runoff curve number for HSG D soil for } \\
& \text { land cover } L ; \\
e & \text { is the natural logarithm base; } \\
a_{g} & \text { is the decay coefficient for land-cover group } \\
& g ;
\end{aligned}
$$

$b_{i} \quad$ is the offset for soil type as follows: 1 for HSG A soil, 2 for HSG B soil and organic soils, 3 for HSG C soil, and 4 for HSG D soil; and

$c_{\mathrm{g}} \quad$ is the $\mathrm{x}$-axis offset for land-cover group $g$.

A subset of root-zone depths in table 4 was also calibrated. Relations specified in the preprocessor were used to calculate additional root-zone depths within each land cover that ensured a logical progression of root-zone depths over different soil types. Root-zone depths are used to determine the maximum soil-water capacity (fig. 2). Root-zone depths for land covers from previous SWB models (for example, Smith and Westenbroek, 2015) indicate a general decline in rootzone depth from more permeable soils (HSG A and B soils) to less permeable soils (HSG C and D soil). In developed, shrubland, grassland, pasture/hay, and wetland land cover, root-zone depths for HSG A, C, and D soils were derived from the HSG B root-zone depth. In forest and cultivated crop land cover, root-zone depths for HSG A, B, and D were derived from the HSG C root-zone depth. An example of an inverse quadratic equation used to calculate root-zone depth is shown in equation 4 :

$$
R Z_{L_{i}}=R S L P_{g b} * b_{i}^{2}+R Z_{L_{B C}}
$$

where

$$
\begin{aligned}
& R Z_{L_{i}} \text { is the root-zone depth for a soil type (HSG A, } \\
& R S L P_{g b} \text { B, C, or D) for each land cover } L \text {, in feet; } \\
& g \text { (urban, forest, grass/cropland, and } \\
& \text { wetland); } \\
& R Z_{L_{B C}} \quad \begin{array}{l}
\text { is the root-zone depth for HSG B or C soil for } \\
\text { land cover } L, \text { in feet; and }
\end{array} \\
& b_{i} \quad \text { is the offset for soil type. }
\end{aligned}
$$

The mean hydraulic conductivities for each land-cover HSG combination that were calculated from the STATSGO2 dataset were incorporated into the model calibration as follows. Within each HSG, the ratio of the mean hydraulic conductivity of each land-cover class to land-cover class 41 (deciduous forest) was determined. Hydraulic conductivity data were normalized to deciduous forest because deciduous forest covered a substantial proportion of the model domain in all HSG types. Additionally, the ratios of the mean hydraulic conductivity of deciduous forest on HSG A soil to mean hydraulic conductivities of deciduous forests on HSGs B, C, D and organic soils were calculated. During parameter estimation, the global parameter, AMAXINF, represented the hydraulic conductivity (maximum recharge rate) of deciduous forest on HSG A soils. The ratios between deciduous forest on A soils and deciduous forest on B, C, D, and organic soils were represented in the calibration as BMAXINF, CMAXINF, DMAXINF, and EMAXINF, respectively. All these parameters (AMAXINF through EMAXINF) were allowed to vary during model calibration, but the hydraulic conductivity ratios among land-cover classes within each HSG were fixed. 


\section{Statistical Methods for Evaluating Model Fit and Model Error}

Several techniques are available to evaluate the ability of a model to accurately and precisely simulate observed conditions. Three general techniques were applied to evaluate the SWB model in this report: graphical analysis, dimensionless model evaluation statistics, and error index model evaluation statistics. Graphical analyses provide a visual comparison of simulated and measured constituent data and a first overview of model performance (American Society of Civil Engineers, 1993).

Dimensionless model evaluation statistics provide a relative model evaluation assessment (Moriasi and others, 2007). Three dimensionless statistics are given: the Nash-Sutcliffe efficiency (NSE) (Nash and Sutcliffe, 1970), the probability plot correlation coefficient (PPCC) of the model residuals (Helsel and Hirsch, 2002), and the root mean squared error (RMSE) to standard deviation ratio of the observed data (RSR).

Error index model evaluation statistics quantify the deviation in the units of the data of interest (Moriasi and others, 2007). Four error index statistics are given: (1) the absolute mean error (AME); (2) the RMSE; (3) the mean residual, and (4) the mean relative error. The model evaluation statistics for individual basins are included in table 5. The NSE, AME, RMSE, RSR, and mean relative error were calculated using the R package HydroGOF, version 0.3-8 (Zambrano-Bigiarini, 2014). The PPCC test was completed using the R package smwrStats, version 0.7.2 (Lorenz, 2015). The predicted (simulated) and observed variables in equations 5, 6, 7, and 8 have units of inches per year.

The NSE is a normalized statistic that determines the relative magnitude of the residual variance ("noise") compared to the measured data variance ("information") (Nash and Sutcliffe, 1970). The NSE indicates how well the plot of observed versus simulated data fits the 1:1 line (Moriasi and others, 2007). For the NSE, a value of 1 is considered a perfect match between the model simulations and observations, a value of 0 denotes that the observed mean is as good a predictor as the model simulations, and negative values for NSE indicate that the observed mean is a better predictor than the model. The NSE was computed by the following equation:

$$
N S E=1-\frac{\sum\left(O_{i}-P_{i}\right)^{2}}{\sum\left(O_{i}-O_{m}\right)^{2}}
$$

where

$$
\begin{aligned}
& \text { NSE is the Nash-Sutcliffe model efficiency } \\
& \text { coefficient; } \\
& n \quad \text { is the number of years of streamflow data at } \\
& \text { each streamgage; } \\
& P_{i} \quad \text { is the predicted (simulated) potential recharge } \\
& \text { value; } \\
& O_{i} \quad \text { is the observed recharge value from } \\
& \text { hydrograph separation; and } \\
& O_{m} \quad \text { is the overall mean of the observed } \\
& \text { hydrograph separation data. }
\end{aligned}
$$

Differences between simulated and observed values of recharge are termed residuals. If the model accurately represents the system, the residuals are expected to be random, independent, and normally distributed (Hill, 1998). The PPCC test evaluates whether or not the model residuals are distributed normally by computing the linear correlation coefficient between data and their normal quantiles. Samples from a normal distribution will have a correlation coefficient very close to 1.0. The null hypothesis in this test is the data are distributed normally, and the alternative hypothesis that the data are not distributed normally. The correlation coefficient $(r)$ between the data and their normal quantiles is tested to see if the correlation coefficient is significantly less than 1.0 (Helsel and Hirsch, 2002). The alpha level of significance was set to 0.05 for this test.

Residuals were calculated as the simulated potential recharge value from the glacial SWB model minus the observed recharge value from base flow, in inches per year. A negative residual indicates the simulated value is lower than the observed value, and a positive residual indicates the simulated value is higher than the observed value. The mean residual is simply the mean of all residuals for a given data aggregation, in inches per year. The mean relative error is the mean residual divided by the mean of the observed data multiplied by 100 .

The AME is a measure of the mean absolute value of the residuals and is calculated according to equation 6 ; for example, an AME of $1.0 \mathrm{in} / \mathrm{yr}$ for the glacial SWB potential recharge value means that this predicted value is on average $1.0 \mathrm{in} / \mathrm{yr}$ different from the observed hydrograph separation value.

$$
A M E=\frac{1}{n} \times \sum\left|P_{i}-O_{i}\right|
$$

where

$$
\begin{aligned}
& A M E \quad \text { is the absolute mean error; } \\
& n \text { is the number of years of streamflow data at } \\
& \text { each streamgage; } \\
& P_{i} \quad \text { is the predicted (simulated) potential recharge } \\
& \text { value; and } \\
& O_{i} \quad \text { is the observed recharge value from } \\
& \text { hydrograph separation. }
\end{aligned}
$$

The RMSE indicates the amount of deviation between the simulated value and the measured value. The RMSE yields the deviation between the simulated (potential recharge value) and measured (hydrograph separation base-flow value) values approximately 67 percent of the time according to the following equation:

$$
R M S E=\sqrt{\frac{1}{n} \times \sum\left(P_{i}-O_{i}\right)^{2}}
$$

where

$R M S E \quad$ is the root mean squared error;

$n \quad$ is the number of years of streamflow data at each streamgage; 
$P_{i} \quad$ is the predicted (simulated) potential recharge value; and

$O_{i} \quad$ is the observed recharge value from hydrograph separation.

Generally, lower RMSE values indicate better model performance; however, for the glacial SWB model, data from a variety of spatial and temporal scales were compared. The RSR incorporates the benefits of error index statistics and includes a scaling/normalization factor so that the resulting statistic and reported values can be compared across different groups of data (Moriasi and others, 2007). The RSR standardizes RMSE using the standard deviation of the observed data, and the RSR combines an error index and additional information recommended by Legates and McCabe (1999). The RSR was computed according to the following equation:

$$
R S R=\sqrt{\frac{\sum\left(\left(O_{i}-P_{i}\right)^{2}\right)}{\sum\left(\left(O_{i}-O_{m}\right)^{2}\right)}}
$$

where

$$
\begin{aligned}
& R S R \quad \text { is the RMSE to standard deviation ratio; } \\
& O_{i} \quad \text { is the observed recharge value from } \\
& \text { hydrograph separation; } \\
& P_{i} \quad \text { is the predicted (simulated) potential recharge } \\
& \text { value; and } \\
& O_{m} \quad \text { is the overall mean of the observed } \\
& \text { hydrograph separation data. }
\end{aligned}
$$

The AME, RMSE, and RSR were evaluated at different scales. These statistics were calculated for the composite model calibration and composite model verification datasets, including all years and all basins of each respective type. These statistics also were calculated for all years for each of the 39 individual calibration basins and each of the 38 individual verification basins.

Moriasi and others (2007) provide general performance ratings for several model evaluation statistics typically used to simulate continuous, long-term streamflow at a monthly time step. Ratings can be relaxed for observations with higher error and tightened for longer time steps. Despite the longer calibration time steps used for the SWB model, these ratings were considered appropriate for this SWB application because of the error inherent to the hydrograph separation method. The thresholds for a model performance rating of "very good" are as follows: RSR (less than 0.50), NSE (greater than 0.75), and statistics that convey bias (such as relative error, within plus or minus 10 percent) (Moriasi and others, 2007).

\section{Model Verification}

Verification basins (fig. 8) had characteristics appropriate for hydrograph separation and were used as an independent evaluation of the SWB model. These basins were not included in model calibration because computation times would have been too long if they were included. For the glacial SWB model, the same acceptance criteria were applied to the verification basins as were applied to the calibration basins.

\section{Simulation of Potential Groundwater Recharge}

This section contains a discussion of the performance of the calibrated model compared to measured base-flow data, a summary of the simulated potential recharge for 1980-2011 in the glacial aquifer system, and a comparison of the glacial SWB model simulation to previously published recharge estimates within the glacial SWB model domain.

\section{Model Fit and Model Error}

The ability of the calibrated glacial SWB model to simulate observed base-flow data is described in this section. Simulated potential recharge values are compared to observed data from 39 calibration basins and 38 verification basins using a variety of techniques. The model fit and error are discussed first in the context of 3 pooled datasets in which values from all 39 basins are combined for each data type: mean annual recharge, deciles of annual recharge, and annual recharge. Model fit and error then are evaluated at the individual basin scale for the calibration basins. Finally, model fit and error are evaluated for mean annual recharge, deciles of annual recharge, and annual recharge pooled datasets of the 38 verification basins.

Potential recharge rates simulated by the glacial SWB model closely matched pooled observed base-flow data for the calibration basins for mean annual recharge, deciles of annual recharge, and annual recharge (table 9). The SWB model produced results that exceeded "very good" ratings (Moriasi and others, 2007) for the statistics NSE, RSR, and mean relative error (table 9). Generally, model results were most accurate for the mean annual recharge dataset which had an NSE of 0.94 and an RMSE of $1.28 \mathrm{in} / \mathrm{yr}$ (table 9). The NSE values indicate that each of the combined calibration datasets approximate a 1:1 relation with the observed data (table 9, fig. 9). The RSR statistic demonstrates that the error of each of the pooled calibration datasets, measured as RMSE, is less than 50 percent of the standard deviation of the observed values. The mean of the residuals for each dataset was small compared to the observed mean recharge rate for all aggregated datasets; the mean relative errors all were less than 10 percent (table 9). Simulated potential recharge values for the aggregated calibration datasets were, on average, between 0.5 and $0.7 \mathrm{in} / \mathrm{yr}$ lower than observed values (mean residuals, table 9). This slight negative bias also is evident in the residual distribution histograms in figure 10. 


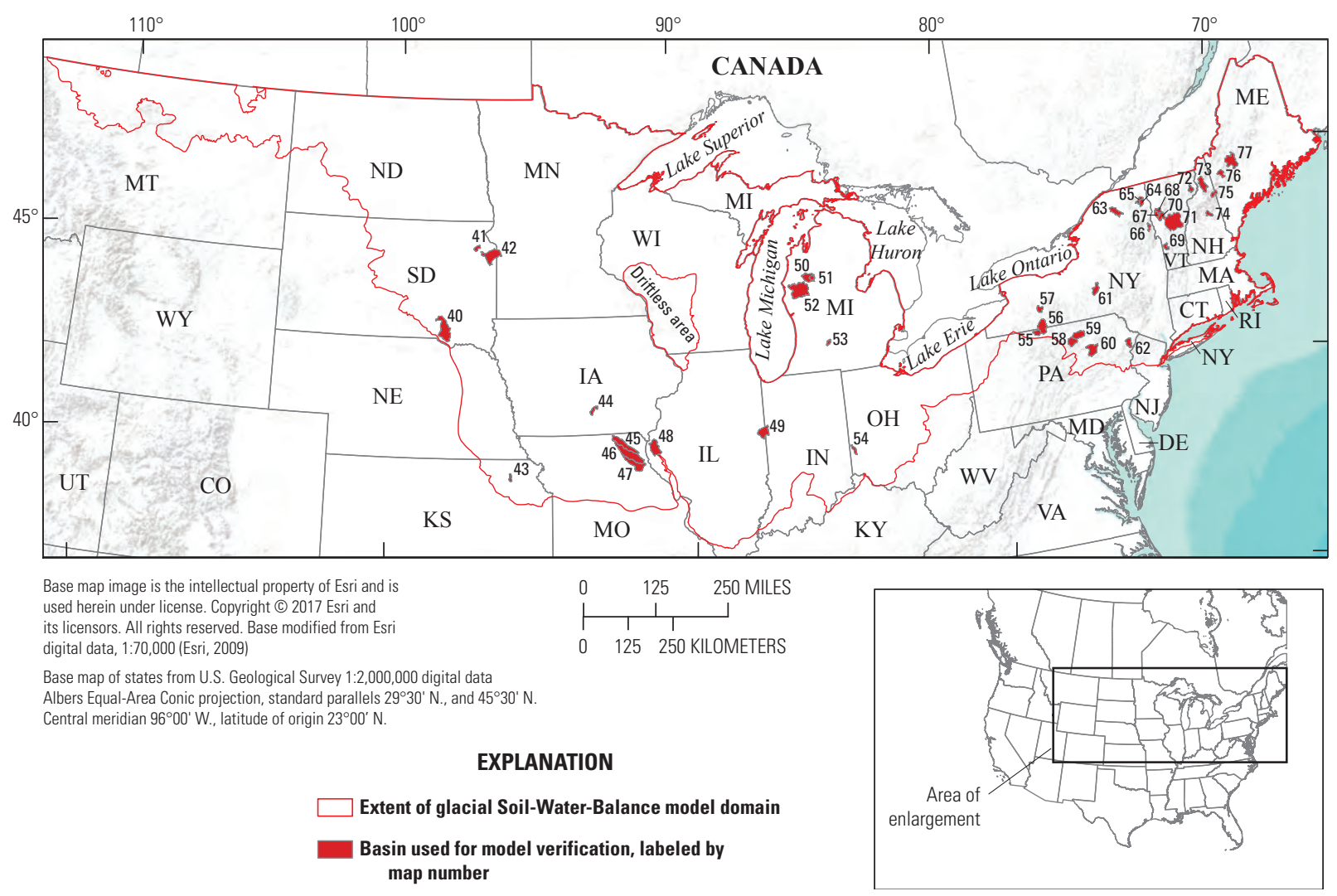

Figure 8. The 38 basins used to verify the glacial Soil-Water-Balance model.

Table 9. Model evaluation statistics between recharge determined with the HYSEP local minimum technique and corresponding potential recharge estimates from the glacial Soil-Water-Balance model for the 39 calibration basins and 38 verification basins.

[NSE, Nash-Sutcliffe model efficiency coefficient; PPCC, probability plot correlation coefficient; RSR, root mean squared error to standard deviation of observations ratio; AME, absolute mean error; RMSE, root mean squared error]

\begin{tabular}{|c|c|c|c|c|c|c|c|c|c|}
\hline \multirow[t]{2}{*}{ Basin type } & \multirow[t]{2}{*}{ Data } & \multirow[t]{2}{*}{$\begin{array}{c}\text { Number of } \\
\text { observations }\end{array}$} & NSE & $\begin{array}{l}\text { PPCC } \\
p \text {-value }\end{array}$ & RSR & AME & RMSE & $\begin{array}{l}\text { Mean } \\
\text { residual }\end{array}$ & \multirow{2}{*}{$\begin{array}{c}\begin{array}{c}\text { Mean } \\
\text { relative } \\
\text { error }\end{array} \\
\text { Percent }\end{array}$} \\
\hline & & & \multicolumn{3}{|c|}{ Dimensionless } & \multicolumn{3}{|c|}{ Inches per year } & \\
\hline \multirow{3}{*}{$\begin{array}{l}\text { Model } \\
\text { calibration }\end{array}$} & Mean annual recharge & 39 & 0.94 & 0.08 & 0.25 & 0.96 & 1.28 & -0.55 & -7.10 \\
\hline & $\begin{array}{l}\text { Deciles of annual } \\
\text { recharge, all basins } \\
\text { combined }^{1}\end{array}$ & 340 & 0.92 & $<0.0005$ & 0.29 & 1.14 & 1.61 & -0.62 & -8.20 \\
\hline & $\begin{array}{l}\text { Annual recharge, all basins } \\
\text { combined }\end{array}$ & 1,191 & 0.83 & $<0.0005$ & 0.41 & 1.68 & 2.27 & -0.54 & -6.90 \\
\hline \multirow{2}{*}{$\begin{array}{l}\text { Model } \\
\quad \text { verification }\end{array}$} & Mean annual recharge & 38 & 0.87 & 0.53 & 0.35 & 1.59 & 2.14 & -0.34 & -3.40 \\
\hline & $\begin{array}{l}\text { Deciles of annual } \\
\text { recharge, all basins } \\
\text { combined }^{1}\end{array}$ & 170 & 0.86 & $<0.0005$ & 0.37 & 1.80 & 2.43 & -0.74 & -6.00 \\
\hline
\end{tabular}

${ }^{1}$ Only includes gages with complete 32 years of record. 

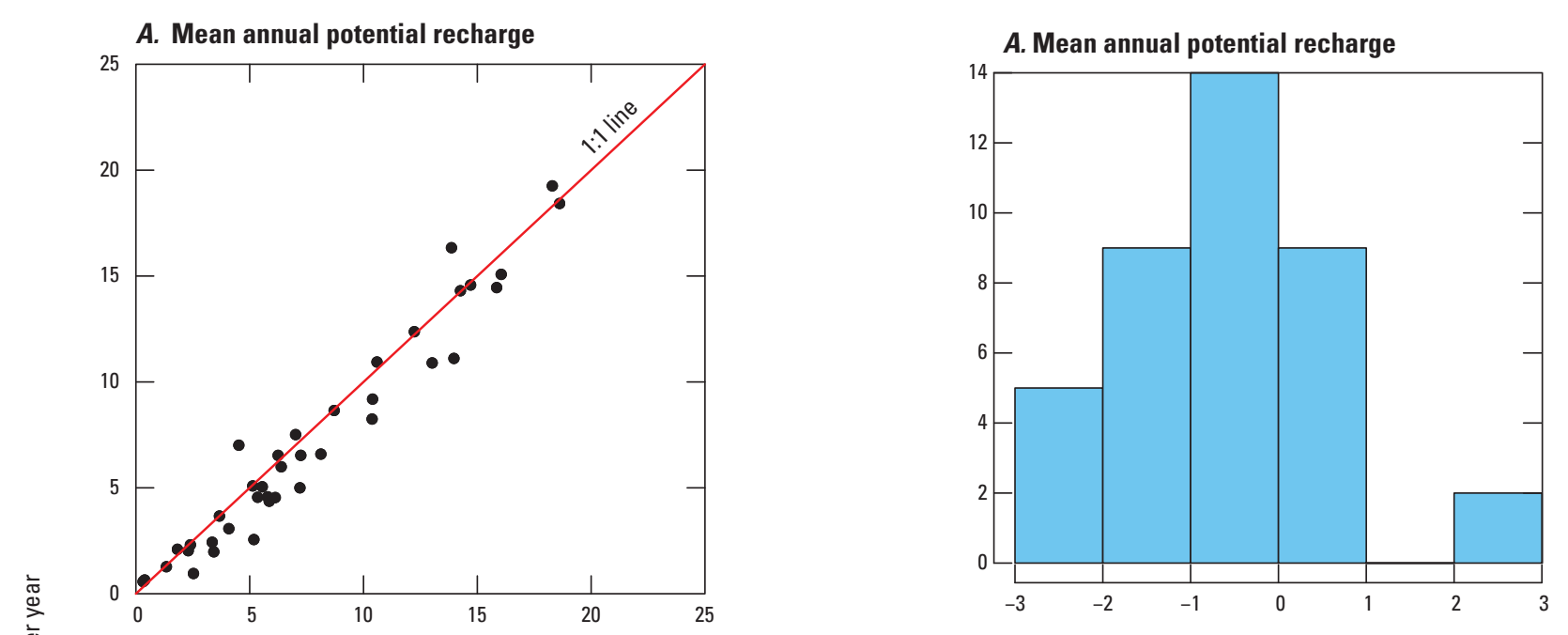

B. Deciles of annual potential recharge

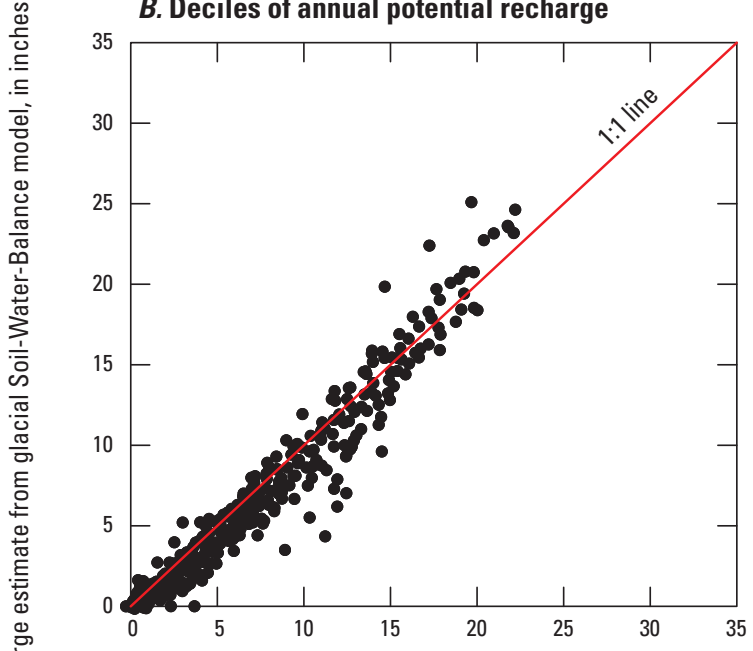

B. Deciles of annual potential recharge

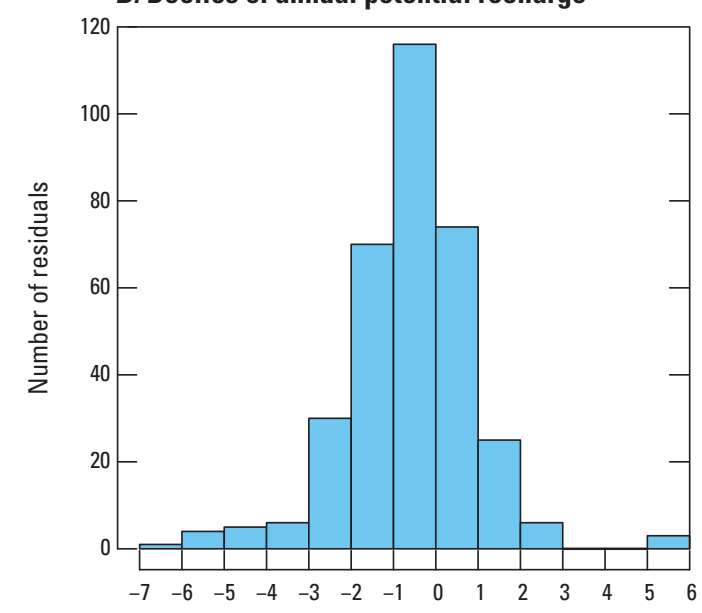

C. Annual potential recharge

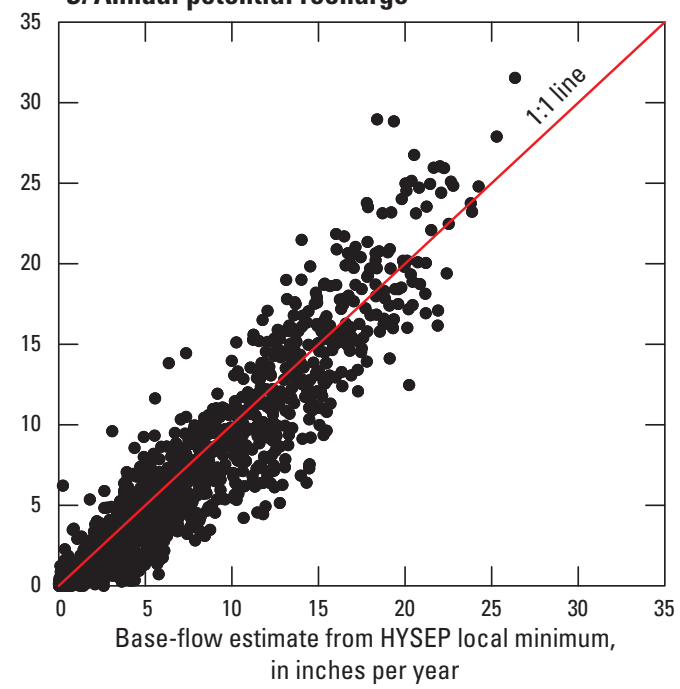

Figure 9. Relations between HYSEP local minimum base flow and potential recharge simulated with the glacial Soil-Water-Balance (SWB) model for 39 calibration basins during 1980-2011. $A$, for mean annual potential recharge; $B$, for deciles of annual potential recharge; and $C$, for annual potential recharge.

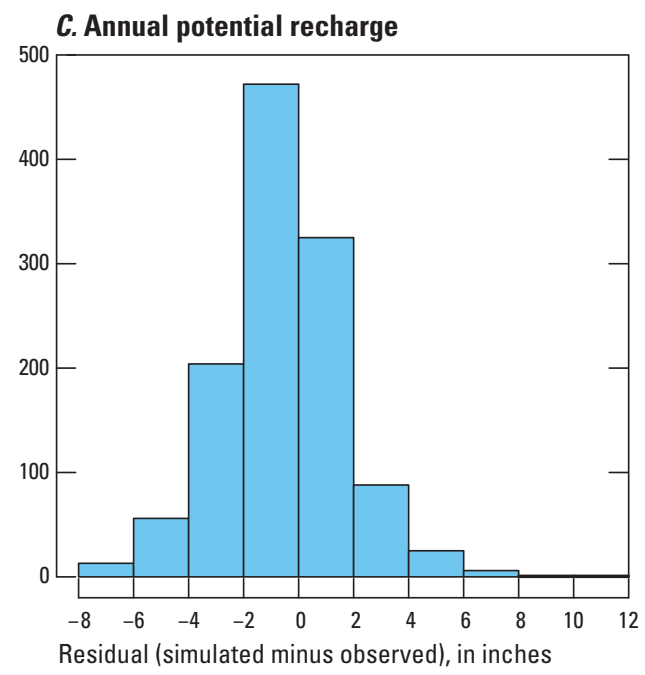

Figure 10. Histogram of residuals (simulated potential recharge from glacial Soil-Water-Balance model minus observed base flow) during 1980-2011. A, for mean annual potential recharge; $B$, for deciles of annual potential recharge; and $C$, for annual potential recharge. 
The residuals between glacial SWB potential recharge and base flow for each of the three pooled datasets were not all normally distributed. Only the residuals from the mean annual calibration dataset were classified as normally distributed according to the PPCC test ( $p$-value $>0.05$, table 9). The nonnormality of the residuals from the deciles of annual recharge resulted from a few extreme outliers; for example, if 11 residual outliers ( 3 high, 8 low) from 5 basins are removed from the decile dataset, which contains 340 data points from 34 basins, the PPCC test indicates the data are normally distributed. The tails of the residual distribution from the pooled annual data were wider than expected for a normal distribution (fig. 10C); therefore, within the pooled annual dataset, large-magnitude residuals were more common than would be expected if the distribution were normal.

Despite good model performance for the pooled data in which all 39 basins were considered together, the SWB model performance was much more variable at the individual basin scale. Mean relative error, AME, and RMSE provide additional information on the uncertainty of the simulated results for the individual calibration basins. The mean relative error for annual recharge comparisons varied from -62.2 percent to 81.4 percent (table 5). The mean relative error for deciles of annual recharge comparisons varied from -63.2 percent to 110.9 percent (table 5). A total of 21 of 39 basins had a mean relative error of more than 10 percent for annual recharge, and 18 of 34 basins had a mean relative error of more than 10 percent for deciles of annual recharge (table 5). The mean relative error and the AME generally varied according the magnitude of the observed recharge rate. The mean relative error tended to increase as the observed recharge rate decreased, and the AME tended to increase as the observed recharge rate increased (table 5). For the annual recharge comparisons, the AME ranged from 0.44 to $3.50 \mathrm{in} / \mathrm{yr}$. For the deciles of annual recharge comparisons, the AME ranged from 0.12 to $3.18 \mathrm{in} / \mathrm{yr}$. In both cases, the poorest model fit was in Michigan (fig. 11).

Spatially, the SWB model tended to underpredict recharge relative to hydrograph separation for mean annual recharge in the Midwest in the States of Minnesota, Iowa, Nebraska, Wisconsin, Illinois, Indiana, and Michigan (fig. 11). The residuals were not correlated strongly to the percentage

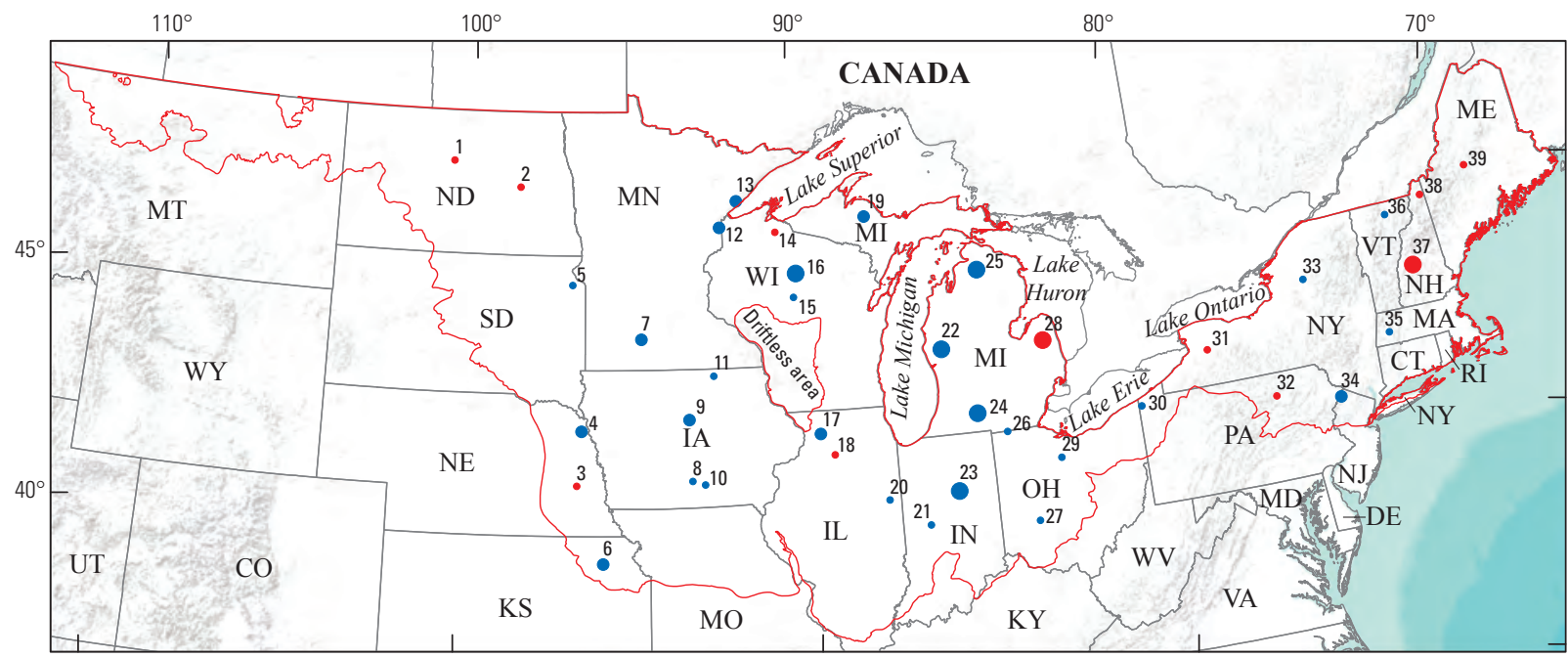

Base map image is the intellectual property of Esri and is used herein under license. Copyright (c) 2017 Esri and its licensors. All rights reserved. Base modified from Esri digital data, 1:70,000 (Esri, 2009)

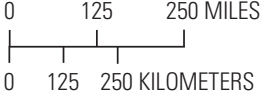

Base map of states from U.S. Geological Survey 1:2,000,000 digital data

Albers Equal-Area Conic projection, standard parallels $29^{\circ} 30^{\prime} \mathrm{N}$., and $45^{\circ} 30^{\prime} \mathrm{N}$.

Central meridian $96^{\circ} 00^{\prime} \mathrm{W}$., latitude of origin $23^{\circ} 00^{\prime} \mathrm{N}$.

\section{EXPLANATION}

Extent of glacial Soil-Water-Balance (SWB) model domain

Mean annual potential recharge residual during 1980-2011, in inches

SWB underpredicts SWB overpredicts

- -3.00 to $-2.01 \quad 0$ to 1.00

- -2.00 to $-1.01 \quad 1.01$ to 2.00

- -1.00 to $0 \quad 2.01$ to 3.00

Figure 11. Residuals in mean annual potential recharge between the glacial Soil-Water-Balance model and base flow determined with the HYSEP local minimum method for the 39 calibration basins during 1980-2011. 
of any of the land-cover classes or HSG classes within the calibration basins (data not shown), indicating a variety of explanations for the low values of recharge simulated by the glacial SWB model for the Midwestern calibration basins; for example, two Michigan basins (map numbers 22 and 25) had large negative recharge residuals of -2.12 in. and -2.86 in., respectively (fig. 11). The basins had the highest proportion of HSG A soils, the highest percentage of sand in the soils (Falcone, 2011), and the highest proportion of streamflow as base flow of all the calibration basins (table 5). The glacial SWB model underpredicted recharge compared to base flow in these basins with such sandy conditions. Thought not a strong correlation, residuals tended to be more negative as the percentage of HSG A soils increased in calibration basins (data not shown), indicating that the glacial SWB model may underpredict recharge in sandy areas.

In another example, a basin in Indiana (map number 23, fig. 11) was 95 percent row crop land cover on HSG C soils, which means recharge simulations in this basin were extremely sensitive to adjustments in parameters representing row crops on HSG C soils (table 4). This basin represents an extreme case in which one land-cover class and HSG combination dominated the basin. The glacial SWB model underpredicted recharge in this basin.
The SWB model underpredicted recharge for another basin in the Upper Peninsula of Michigan (map number 19, fig. 11). This basin had the highest percent area (27 percent) of wetland land cover of all the calibration basins. Calibration basins were specified to have less than 25 percent wetland cover according to GAGES II; however, when the NLCD land-cover data were rescaled to $1 \mathrm{~km}$, the model input data contained 27 percent wetland cover. As described in the "Model Limitations and Assumptions" section, tthe SWB model does not fully represent processes occurring in areas where the water table regularly intersects land surface.

Variability in recharge derived from hydrograph separation methods differs among the calibration basins. The range of mean annual recharge rates determined with the five hydrograph separation methods and the mean annual potential recharge rates simulated with the glacial SWB model are shown in figure 12. Map numbers in this figure correspond to figures 1 and 11 and generally increase from west to east. For the mean annual dataset, simulated potential recharge rates were within the range of base-flow recharge rates in 23 of 39 calibration basins (fig. 12). Generally, as the mean annual base flow ("observed" data for model calibration) increased, the range in base-flow values from the five methods of hydrograph separation also increased (fig. 12). The coefficient of

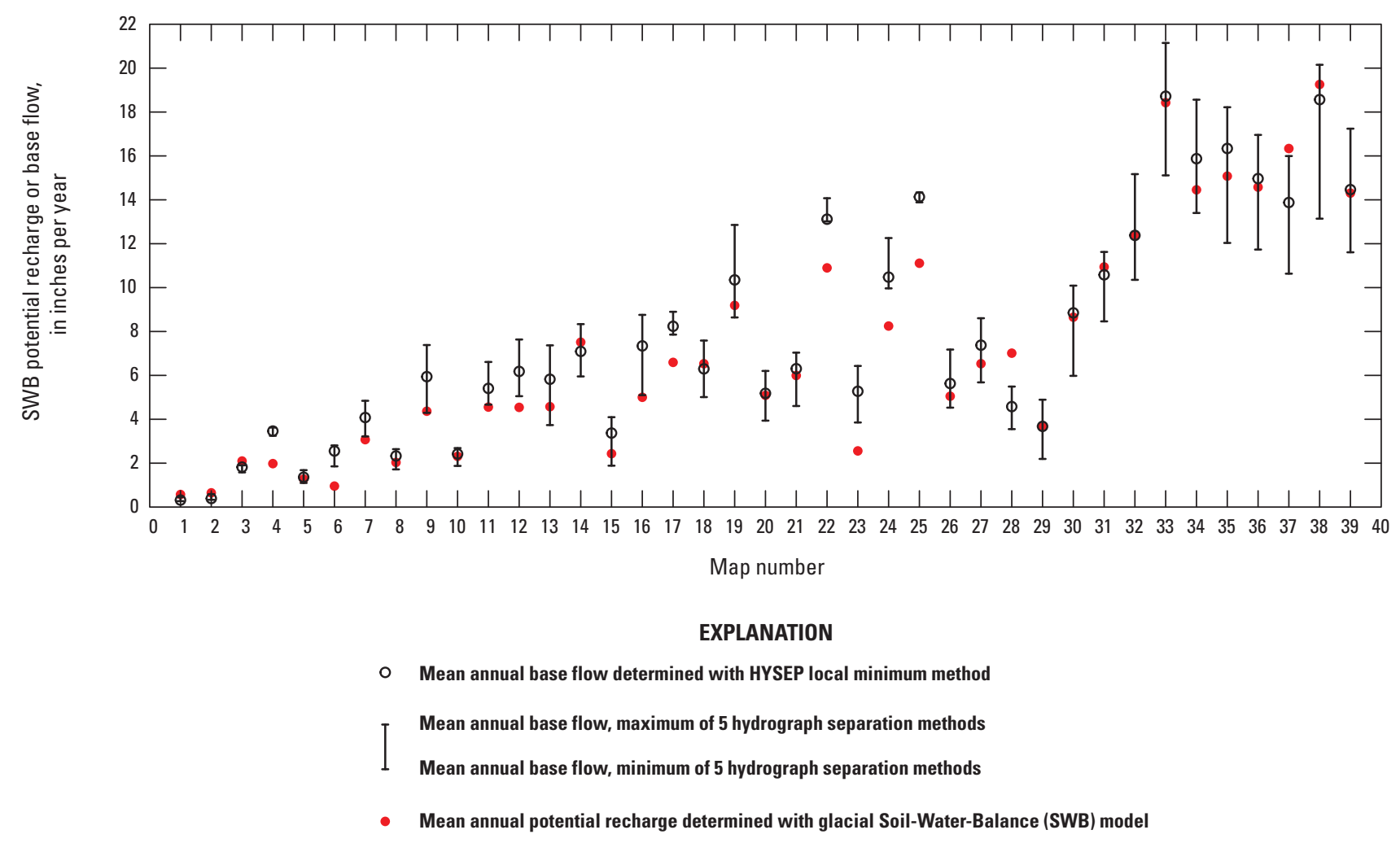

Figure 12. Mean annual potential recharge from the glacial Soil-Water-Balance model, mean annual HYSEP local minimum base flow, and range of mean annual base flow from five hydrograph separation techniques, PART, HYSEP local minimum, HYSEP fixed-interval, HYSEP sliding, and base-flow index during 1980-2011. 
variation (standard deviation divided by the mean) of the five hydrograph separation methods (table 5) was fairly consistent in the calibration basins, averaging about 15 percent, indicating that there is a consistent relative amount of variability in hydrograph separation methodology.

After the model was calibrated, simulated recharge rates were compared to base flow from 38 verification basins. Potential recharge rates simulated by the glacial SWB model closely matched pooled base-flow data from the verification basins for mean annual recharge, deciles of annual recharge, and annual recharge. The SWB model produced results that exceeded "very good" ratings (Moriasi and others, 2007) for NSE, RSR, and mean relative error statistics (table 9). As with the calibration dataset, the model produced the most accurate results for the mean annual recharge dataset which had an NSE of 0.87 and an RMSE of $2.14 \mathrm{in} / \mathrm{yr}$ (table 9). The NSE indicates that each of the combined calibration datasets approximates a 1:1 relation with the observed data (table 9, fig. 13). The RSR demonstrates that the error of each of the combined calibrated datasets, measured as RMSE, is less than 50 percent of the standard deviation of the observed values. The mean of the residuals for each dataset was small compared to observed mean recharge rates for all aggregated datasets; the mean relative errors all were less than 10 percent (table 9). Simulated potential recharge values for the aggregated calibration datasets were, on average, between 0.3 and $0.8 \mathrm{in} / \mathrm{yr}$ lower than observed values (mean residuals, table 9). The residuals of the mean annual recharge dataset were distributed normally (PPCC test $p$-value $=0.53$, table 9). A full discussion of the model fit and error for the verification basins is not included here, but summary statistics are provided in table 5 for all the verification basins.
In conclusion, the calibrated glacial SWB model adequately reproduced the observed recharge for the calibration and verification basins. Most statistical measures applied for model evaluation indicated acceptable results. Some parts of the model domain had lower error rates than others. Generally, deviations between simulated and observed recharge were largest in the upper Midwest. Model evaluation statistics indicated that the model most accurately simulated the mean annual recharge. Variability in recharge derived from hydrograph separation methods differed among the calibration basins.

\section{0-2011 Potential Recharge to the Glacial Aquifer System}

The calibrated glacial SWB model was used to simulate potential groundwater recharge rates for the glacial aquifer system for 1980-2011. The year 1980 was run first to establish initial conditions, and then the model was started again at 1980 and run for the period. The glacial SWB model encompasses a broad range of climatic conditions, from semiarid in the west to humid in the east. The broad range of climatic conditions is reflected in the potential recharge rates. Most cells in the western part of the model had an average potential recharge rate of less than $3 \mathrm{in} / \mathrm{yr}$, whereas most cells in the eastern part of the model had potential recharge rates of more than $20 \mathrm{in} /$ yr (fig. 14). The glacial SWB model simulated a mean annual potential recharge rate of $0.6 \mathrm{in} / \mathrm{yr}$ for the westernmost calibration basin (map number 1, fig. 1) and a mean annual potential recharge rate of $19.3 \mathrm{in} / \mathrm{yr}$ for one of the easternmost basins
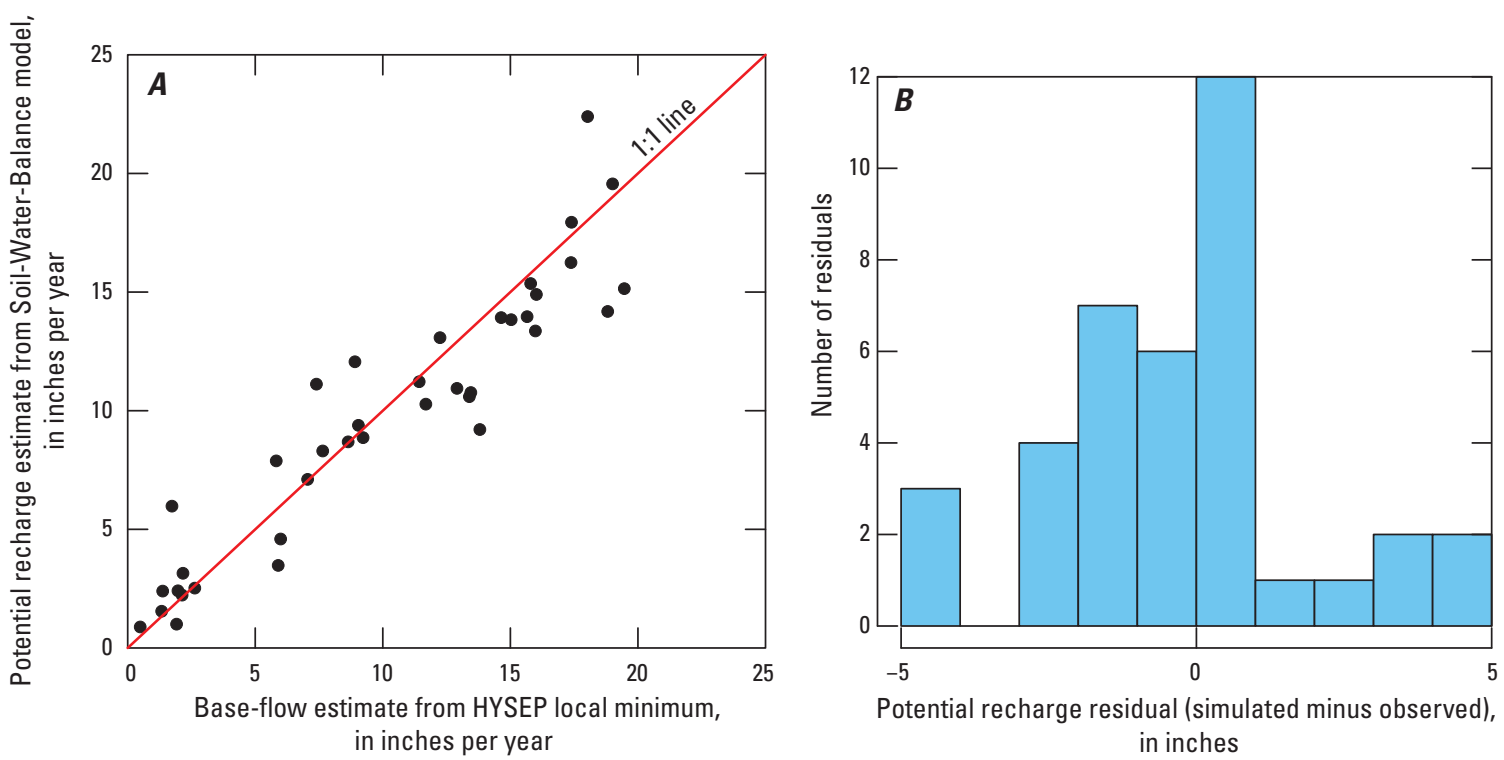

Figure 13. Mean annual HYSEP local minimum base flow and mean annual potential recharge simulated with the glacial Soil-Water-Balance model for 38 verification basins. $A$, showing relation between them; and $B$, showing residuals. 


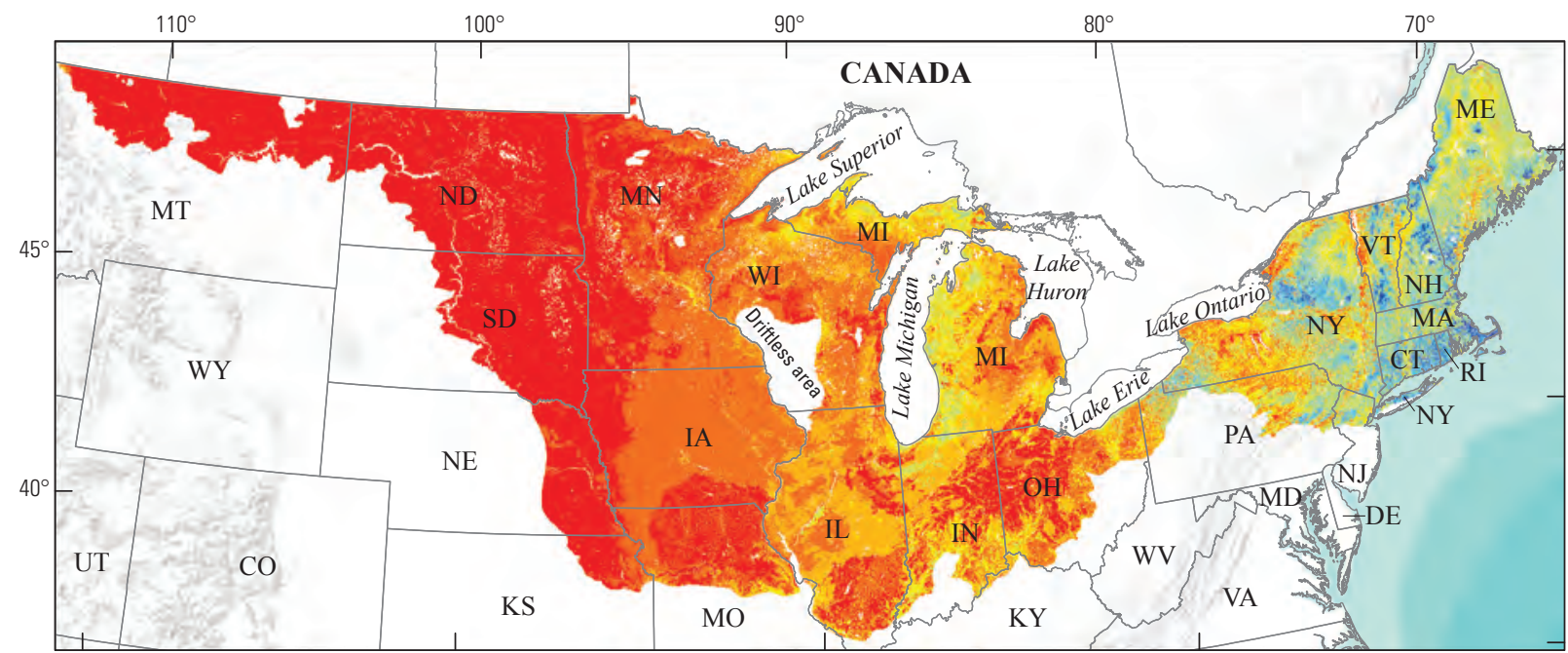

Base map image is the intellectual property of Esri and is used herein under license. Copyright (c) 2017 Esri and its licensors. All rights reserved. Base modified from Esr digital data, 1:70,000 (Esri, 2009)

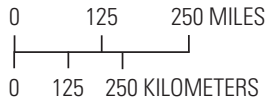

Base map of states from U.S. Geological Survey 1:2,000,000 digital data

Albers Equal-Area Conic projection, standard parallels $29^{\circ} 30^{\prime} \mathrm{N}$., and $45^{\circ} 30^{\prime} \mathrm{N}$.

Central meridian $96^{\circ} 00^{\prime}$ W., latitude of origin $23^{\circ} 00^{\prime} \mathrm{N}$.

\section{EXPLANATION}

Glacial Soil-Water-Balance model mean annual potential recharge, in inches per year

\begin{tabular}{|l|l|}
\hline \begin{tabular}{l}
0 to 3.00 \\
\hline 3.01 to 6.00
\end{tabular} & 15.01 to 18.00 \\
\hline 6.01 to 9.00 & 21.01 to 21.00 \\
\hline 9.01 to 12.00 & 24.00 \\
\hline 12.01 to 15.00 & 27.01 to 27.00 \\
\hline
\end{tabular}

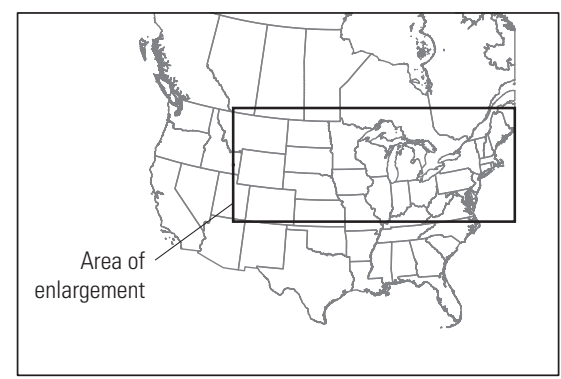

Figure 14. Mean annual potential recharge from 1980 to 2011 simulated with the glacial Soil-Water-Balance model.

(map number 38, fig. 1). Nearly 20 percent of model cells had an average potential recharge rate of less than $1 \mathrm{in} / \mathrm{yr}$ (fig. 15).

The calibrated glacial SWB model provides insight into variability of annual potential recharge rates. Annual potential recharge grids for the domain for 1980-2011 are available with the model archive (Trost, 2018). As an alternate method of visualizing variability, a cumulative distribution function was calculated for each model cell for 1980-2011. Maps of the 10 percent potential recharge quantile and 90 percent potential recharge quantile for each model cell are shown in figure 16 (note: this figure shows model output and should not be confused with the decile base-flow calibration targets). The 10 percent potential recharge quantile represents dry, low potential recharge conditions, specifically the probability that annual potential recharge at that location will be that value or lower 10 percent of the time. Conversely, the 90 percent potential recharge quantile represents wet, high potential recharge conditions, specifically the probability that annual potential recharge at that location will be that value or higher 10 percent of the time. At the 10 percent potential recharge quantile, the mean potential recharge rate of the model domain is $3.0 \mathrm{in} / \mathrm{yr}$, and the median potential recharge rate is $1.5 \mathrm{in} / \mathrm{yr}$.
A total of 43 percent of model cells (or nearly half of the active model area) have less than $1.0 \mathrm{in} / \mathrm{yr}$ of potential recharge, and 77 percent of model cells have less than $5.0 \mathrm{in} / \mathrm{yr}$ of potential recharge (fig. 16A). In contrast, in the 90 percent potential recharge quantile, the mean potential recharge rate is $9.0 \mathrm{in} / \mathrm{yr}$, and the median potential recharge rate is $8.0 \mathrm{in} / \mathrm{yr}$. Only $11 \mathrm{per}-$ cent of model cells have less than $1.0 \mathrm{in} / \mathrm{yr}$ of potential recharge, and only 37 percent of model cells have less than $5.0 \mathrm{in} / \mathrm{yr}$ of potential recharge (fig. 16B).

The calibrated SWB model outputs demonstrate the interacting effects of land use, soil type, and precipitation on potential recharge (table 10, figs. 17, 18). Forest (25 percent of area) and agriculture (48 percent of area) are the two dominant land-cover types within the model area (fig. 4; tables 1,2,3). Approximately 46 percent of the potential recharge in the active model domain was in forested areas (fig. 17A, deciduous, evergreen, and mixed forest), and about 30 percent of the potential recharge was in agricultural areas (fig. 17 $\mathrm{A}$, pasture/hay and cultivated crops). Approximately 39 percent of all the potential recharge in the glacial aquifer system travels through highly disturbed land-cover types, including developed and agricultural areas (figs. 4, 17A), which are known to cause water-quality impairments. 


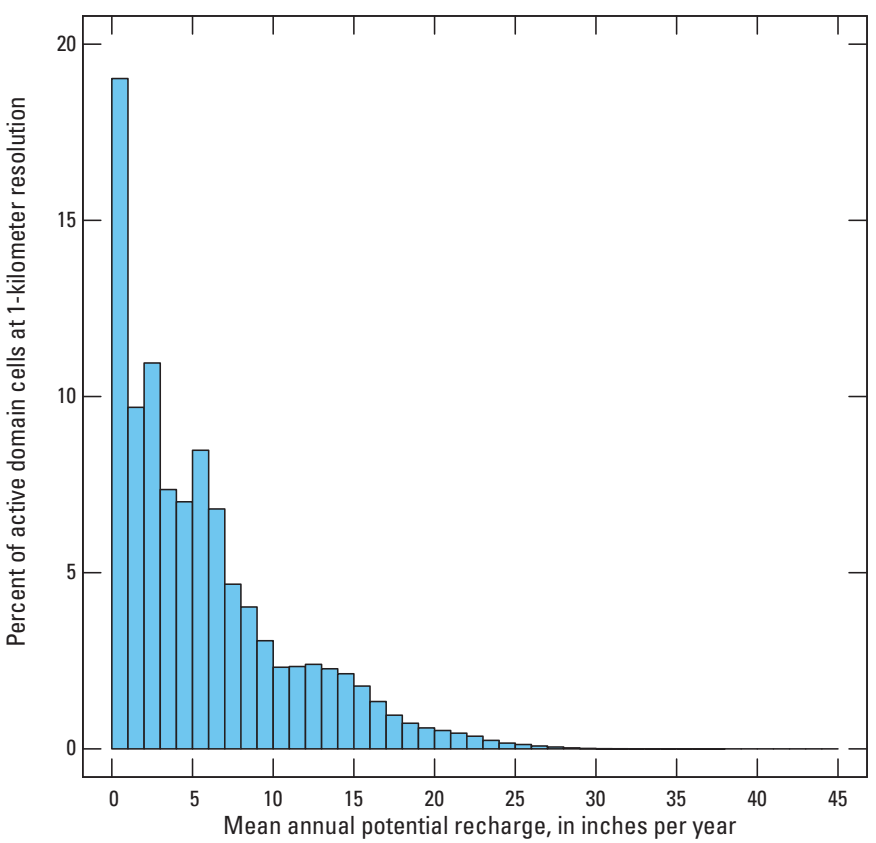

Figure 15. Histogram (by percent) of mean annual potential recharge from the glacial Soil-Water-Balance model during 1980 to 2011 for the glacial aquifer system.
Most of the land area west of Indiana and Michigan consists of HSG B, and most of the land area from Indiana to the east consists of HSG C (fig. 5). The HSG C soils have higher curve numbers than HSG B soils (table 4), which means, under identical hydrologic conditions, HSG C soils will generate more runoff and less potential recharge than HSG B soils. However, because HSG $\mathrm{C}$ soils are more common in areas of higher precipitation (figs. 3 and 5), the mean potential recharge through HSG C soils was greater than the mean potential recharge through HSG B soils (table 10). The HSG B soils covered much more of the model domain (42.4 percent) than HSG C soils (29.6 percent); therefore, potential recharge was slightly higher in HSG B soils than HSG C soils (tables 1,2,3; figs. 5, 17B). Sandy areas belonging to HSG A were a small proportion of the model area $(7.4$ percent, tables $1,2,3)$ but contributed about 15 percent of the total potential recharge (fig. 17B).

Total precipitation and the relative amount of precipitation that becomes recharge vary from west to east (fig. 18). In North Dakota, mean precipitation generally is less than $20 \mathrm{in} / \mathrm{yr}$ (fig. 3), and potential recharge generally is less than 4 percent of precipitation (fig. 18). Conversely, in Maine, mean precipitation generally is above $40 \mathrm{in} / \mathrm{yr}$ (fig. 3), and potential recharge generally is at least 18 percent of precipitation.

Table 10. Mean annual potential recharge rates simulated by the glacial Soil-Water-Balance model, by land-cover class and hydrologic soil group, for the period 1980-2011.

[The glacial domain area-weighted mean by land-cover class and hydrologic soil group is an area-weighted mean potential recharge estimate for the entire glacial model domain for active cells; NA, not applicable]

\begin{tabular}{|c|c|c|c|c|c|c|c|}
\hline \multirow[b]{2}{*}{$\begin{array}{l}\text { Land-cover } \\
\text { class }\end{array}$} & \multirow[b]{2}{*}{ Description } & \multicolumn{6}{|c|}{ Mean annual potential recharge (inches per year) } \\
\hline & & $\begin{array}{c}\text { Hydrologic } \\
\text { soil group } \\
\text { A }\end{array}$ & $\begin{array}{c}\text { Hydrologic } \\
\text { soil group } \\
\text { B }\end{array}$ & $\begin{array}{l}\text { Hydrologic } \\
\text { soil group } \\
\text { C }\end{array}$ & $\begin{array}{c}\text { Hydrologic } \\
\text { soil group } \\
\text { D }\end{array}$ & $\begin{array}{l}\text { Organic } \\
\text { soil group }\end{array}$ & $\begin{array}{c}\text { Glacial domain } \\
\text { area-weighted } \\
\text { mean, by land- } \\
\text { cover class }\end{array}$ \\
\hline 21 & Developed, open space & 14.46 & 7.66 & 8.45 & 4.58 & 7.67 & 8.55 \\
\hline 22 & Developed, low intensity & 16.89 & 9.12 & 8.14 & 5.64 & 8.76 & 9.67 \\
\hline 23 & Developed, medium intensity & 18.48 & 9.65 & 11.01 & 6.94 & 9.51 & 11.36 \\
\hline 24 & Developed, high intensity & 16.10 & 7.35 & 8.13 & 8.10 & 5.62 & 9.14 \\
\hline 31 & Barren land (rock/sand/clay) & 14.87 & 8.94 & 10.82 & 3.60 & 8.63 & 9.84 \\
\hline 41 & Deciduous forest & 10.45 & 8.28 & 11.04 & 4.80 & 6.35 & 9.69 \\
\hline 42 & Evergreen forest & 10.79 & 8.32 & 12.87 & 8.17 & 7.00 & 11.25 \\
\hline 43 & Mixed forest & 12.66 & 9.18 & 13.17 & 10.77 & 6.52 & 12.38 \\
\hline 52 & Shrubland & 11.89 & 8.49 & 9.05 & 2.81 & 6.42 & 8.29 \\
\hline 71 & Grasslands & 6.34 & 1.52 & 0.44 & 0.28 & 7.38 & 1.27 \\
\hline 81 & Pasture/hay & 8.51 & 3.88 & 2.59 & 0.26 & 4.41 & 3.36 \\
\hline 82 & Cultivated crops & 8.72 & 3.96 & 1.73 & 1.90 & 6.25 & 3.42 \\
\hline 90 & Woody wetlands & 10.42 & 8.05 & 10.43 & 7.65 & 5.31 & 8.49 \\
\hline 95 & Herbaceous wetlands & 8.33 & 4.31 & 5.82 & 5.34 & 5.00 & 5.31 \\
\hline NA & $\begin{array}{l}\text { Glacial domain area-weighted mean, } \\
\text { by hydrologic soil group }\end{array}$ & 10.49 & 4.83 & 6.64 & 2.58 & 5.67 & NA \\
\hline
\end{tabular}




\section{A. 10th percentile annual potential recharge}

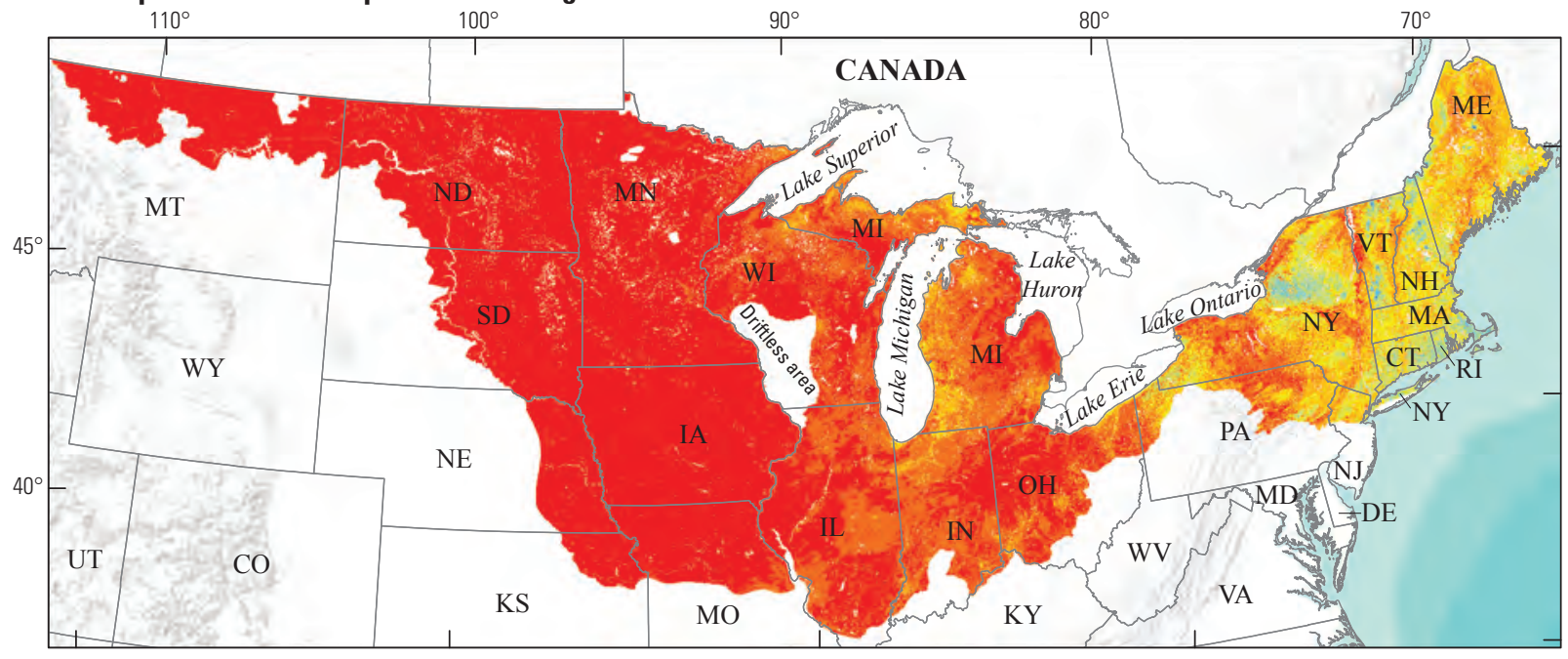

Base map image is the intellectual property of Esri and is used herein under license. Copyright (C) 2017 Esri and its licensors. All rights reserved. Base modified from Esri digital data, 1:70,000 (Esri, 2009)

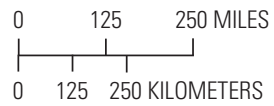

Base map of states from U.S. Geological Survey 1:2,000,000 digital data

Albers Equal-Area Conic projection, standard parallels $29^{\circ} 30^{\prime} \mathrm{N}$., and $45^{\circ} 30^{\prime} \mathrm{N}$.

Central meridian $96^{\circ} 00^{\prime} \mathrm{W}$., latitude of origin $23^{\circ} 00^{\prime} \mathrm{N}$.

\section{EXPLANATION}

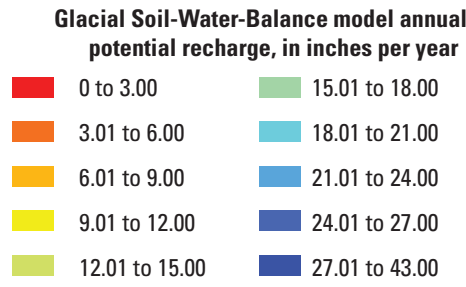

\section{B. 90th percentile annual potential recharge}

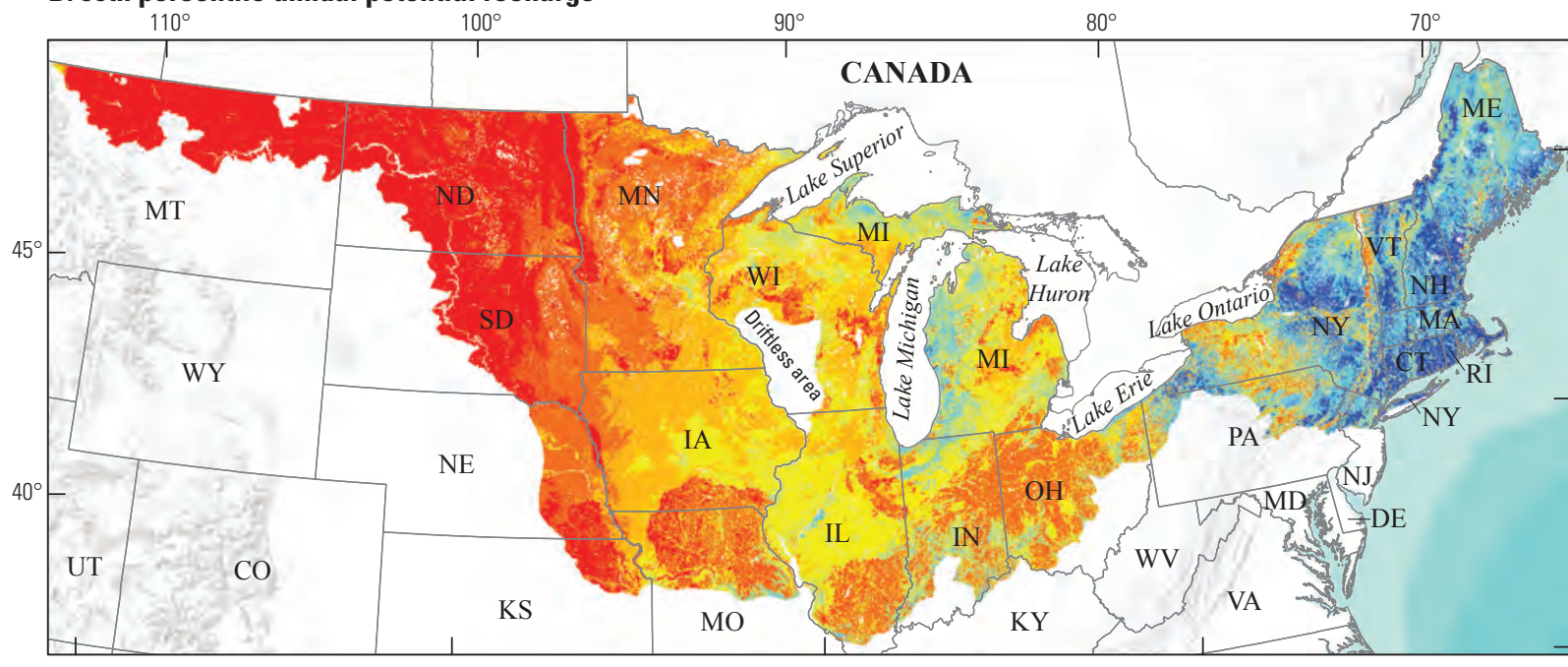

Base map image is the intellectual property of Esri and is used herein under license. Copyright $(\complement) 2017$ Esri and its licensors. All rights reserved. Base modified from Esri digital data, 1:70,000 (Esri, 2009)

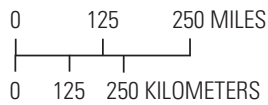

Base map of states from U.S. Geological Survey 1:2,000,000 digital data Albers Equal-Area Conic projection, standard parallels $29^{\circ} 30^{\prime} \mathrm{N}$., and $45^{\circ} 30^{\prime} \mathrm{N}$. Central meridian $96^{\circ} 00^{\prime}$ W., latitude of origin $23^{\circ} 00^{\prime} \mathrm{N}$.

Figure 16. Results from the glacial Soil-Water-Balance model. $A$, 10th percentile annual potential recharge for each grid cell from 1980 to 2011; and B, 90th percentile annual potential recharge for each grid cell from 1980 to 2011. 


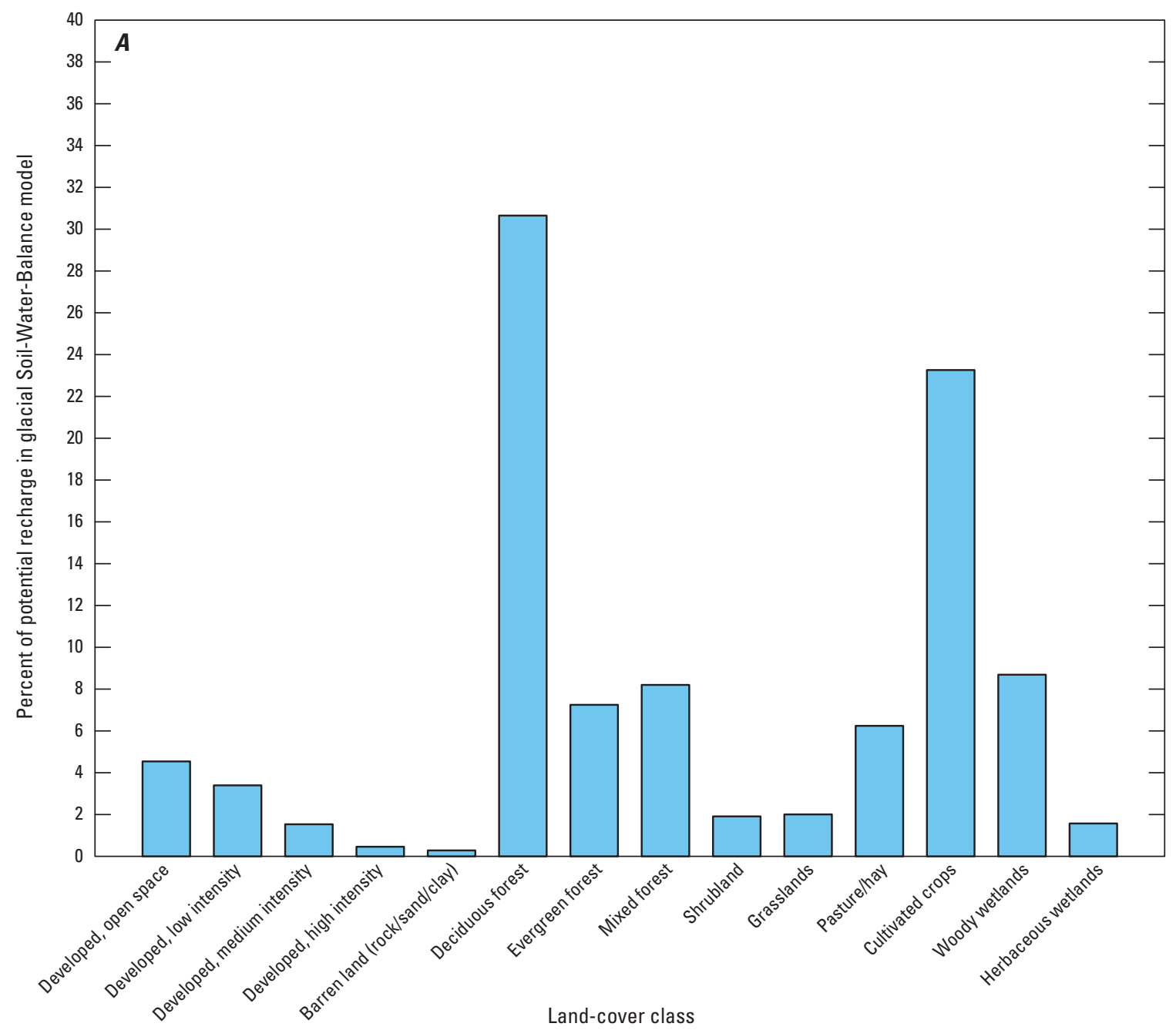

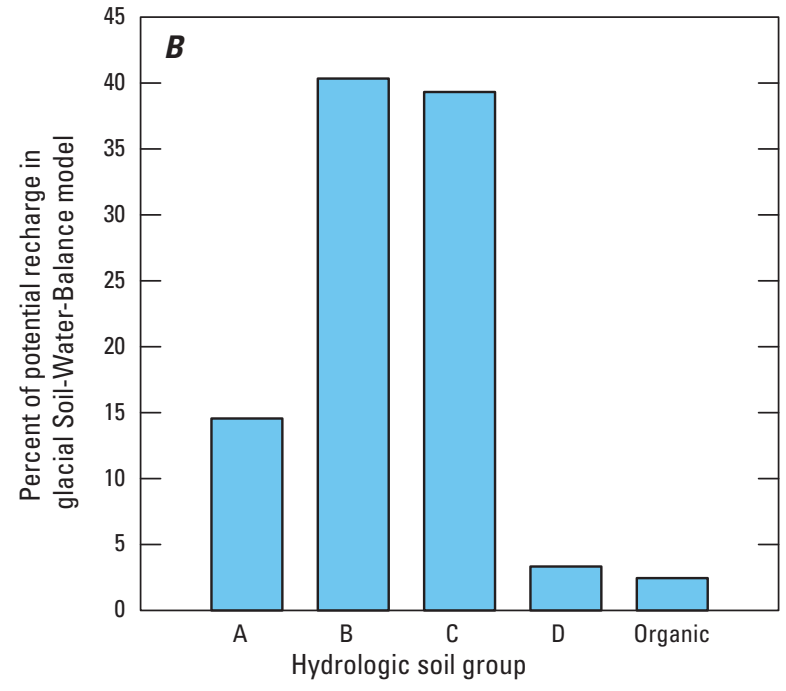

Figure 17. Percent of 1980-2011 potential recharge to the glacial aquifer system. $A$, by land-cover class from 2006 National Land Cover Database; and $B$, by hydrologic soil group (Fry and others, 2011; Natural Resources Conservation Service, 2015). 


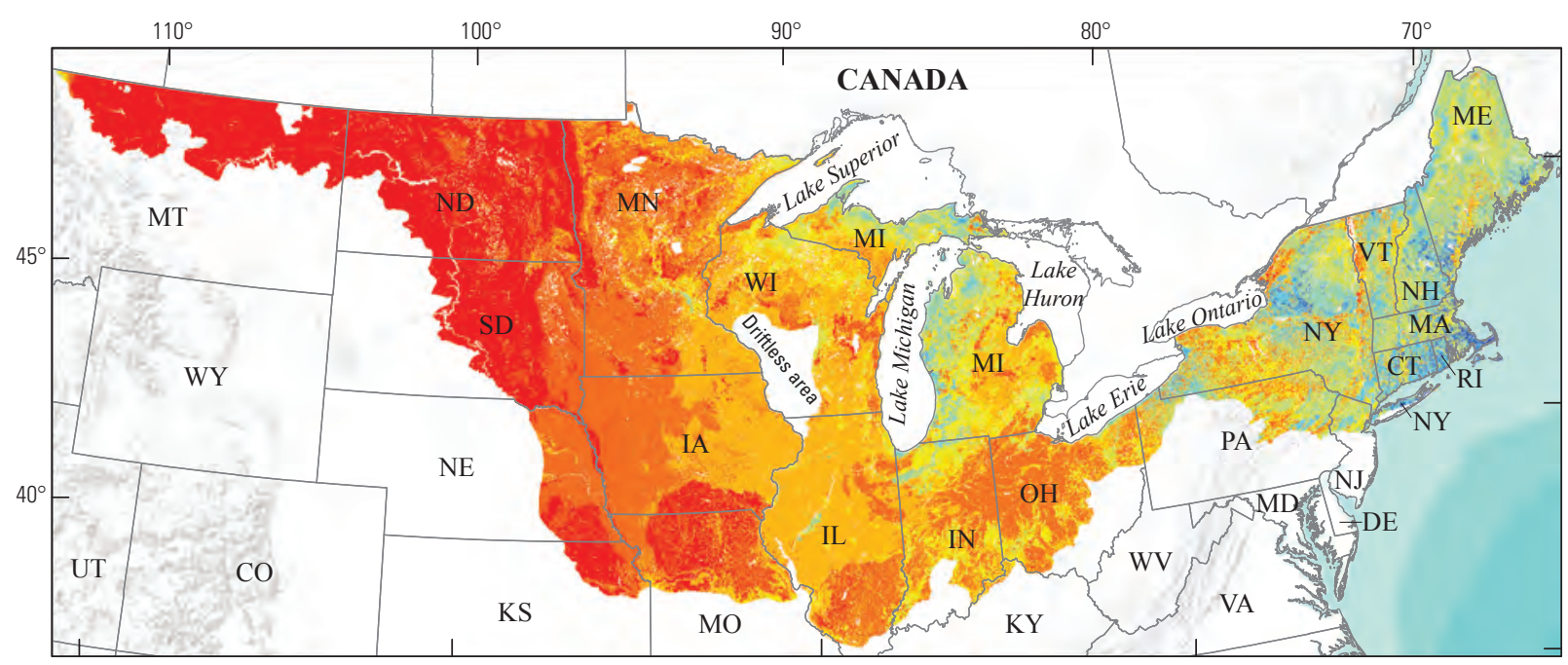

Base map image is the intellectual property of Esri and is used herein under license. Copyright (c) 2017 Esri and its licensors. All rights reserved. Base modified from Esri digital data, 1:70,000 (Esri, 2009)

Base map of states from U.S. Geological Survey 1:2,000,000 digital data Albers Equal-Area Conic projection, standard parallels $29^{\circ} 30^{\prime}$ N., and $45^{\circ} 30^{\prime} \mathrm{N}$

Central meridian $96^{\circ} 00^{\prime}$ W., latitude of origin $23^{\circ} 00^{\prime} \mathrm{N}$.

\section{EXPLANATION}
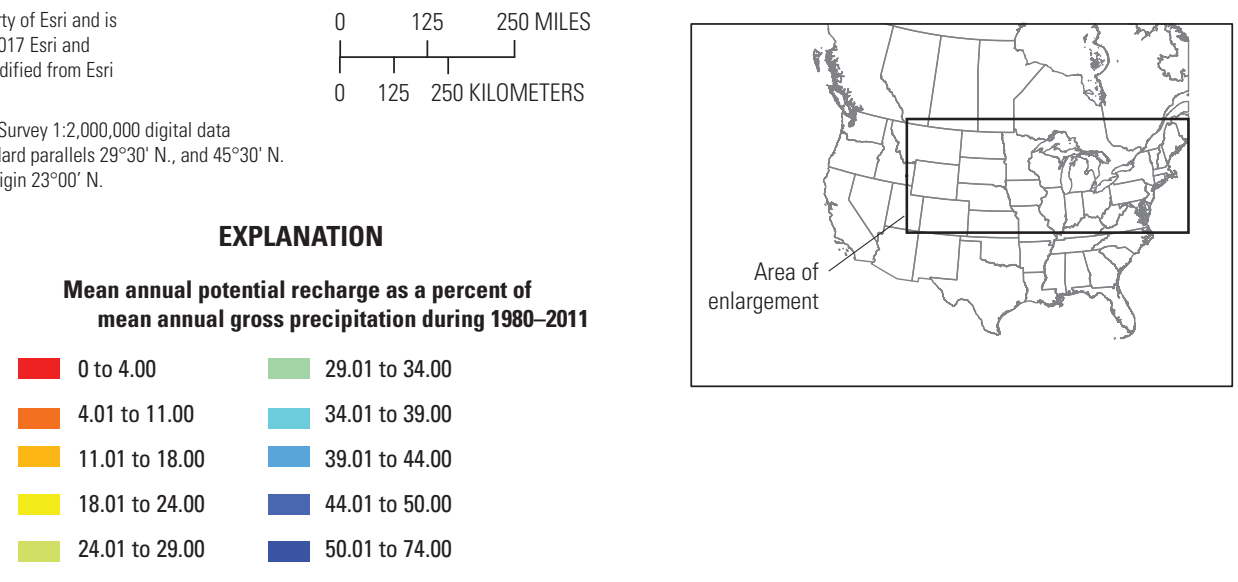

$0 \quad 125 \quad 250$ KILOMETERS

Figure 18. Mean annual potential recharge as a percent of mean annual gross precipitation (Thornton and others, 2014) based on results from the glacial Soil-Water-Balance model.

The calibrated glacial SWB model also demonstrated changes in annual potential recharge through time in the eastern, central, and west-central regions of the glacial aquifer system (figs. 1 and 19), as delineated for the National WaterQuality Assessment. Regional climatic events are apparent in the simulated potential recharge data. Annual potential recharge rates in all three regions generally have been increasing since 2000 (fig. 19). During the years 1987-89, much of the United States was under a severe drought (Trenberth and Branstator, 1992), which is apparent as a series of very low potential recharge years in the west-central and central regions (fig. 19). The lowest potential recharge for the eastern region happened in 2001, a year in which many of the eastern States had well below average precipitation (National Oceanic and Atmospheric Administration, 2002).

\section{Comparison to Previous Recharge Estimates}

The glacial SWB model was compared to several previously published recharge estimates within the glacial SWB model domain: a 1951-80 mean annual recharge rate for the glacial model domain (Wolock, 2003b), the Williston Basin
SWB model (Aurand, 2013), the Minnesota SWB model (Smith and Westenbroek, 2015), and the Appalachian Plateaus SWB model (McCoy and others, 2015). The coincident model boundaries are shown in figure 20, and the distribution of cellby-cell differences is shown in figure 21 . The glacial SWB model simulated mean annual recharge rates generally higher than the 1951-80 mean annual BFI study (Wolock, 2003b), the Williston Basin SWB model (Aurand, 2013), and the Appalachian Plateaus SWB model (McCoy and others, 2015). The glacial SWB model simulated mean annual recharge rates generally lower than the Minnesota SWB model (Smith and Westenbroek, 2015). Possible explanations for these differences are discussed in the following paragraphs.

Wolock (2003b) estimated the mean annual natural groundwater recharge in the conterminous United States using a 1-km resolution (grid) dataset for 1951-80 (figs. 20, 22A). This method provides a single long-term average recharge smoothed over large areas and does not take explicitly into account local variations in soil hydrologic characteristics and land cover (fig. 22A). In contrast, the SWB model accounts for local variability and provides recharge estimates with greater spatial and temporal resolution (figs. 16, 22B). 


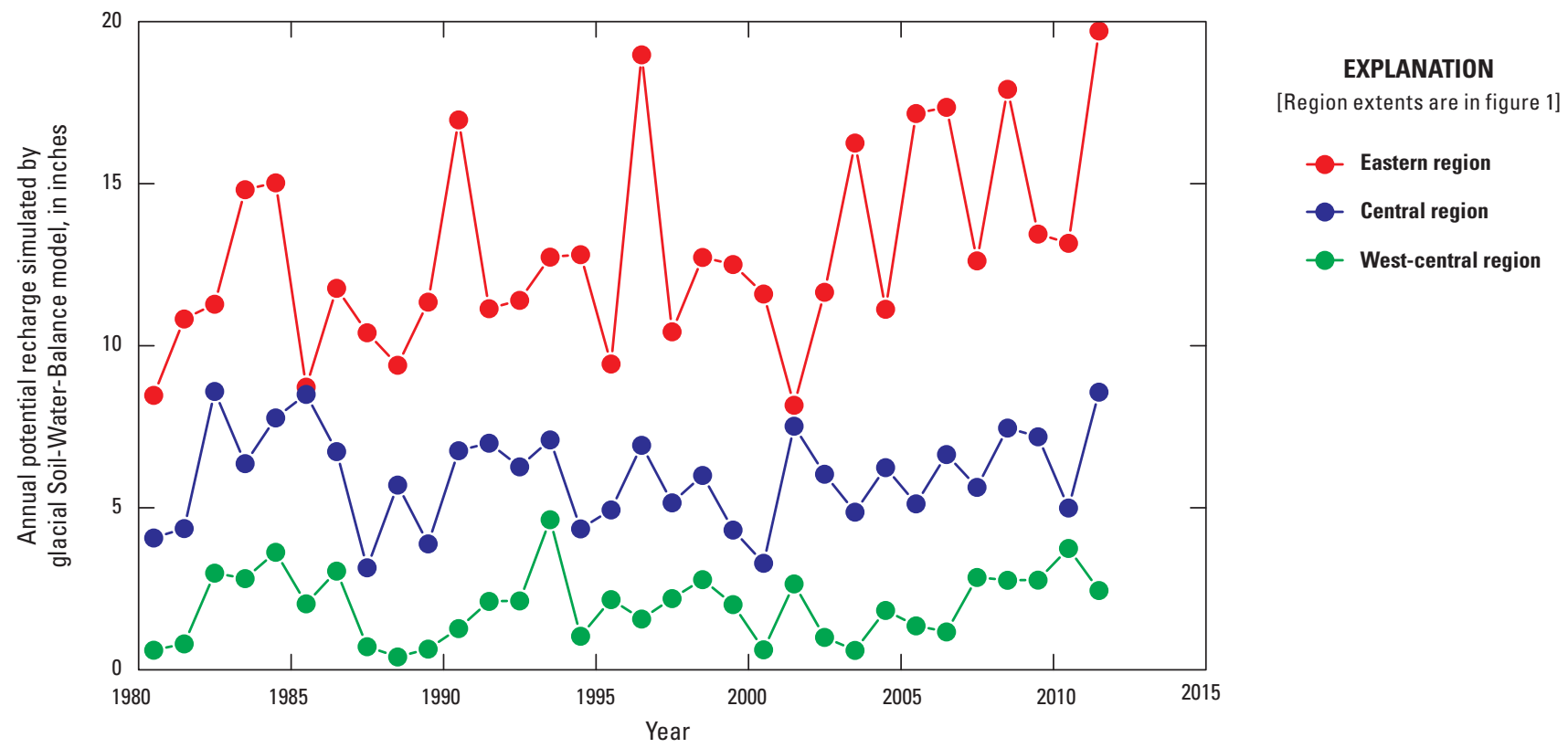

Figure 19. Annual potential recharge from 1980 to 2011 simulated with the glacial Soil-Water-Balance model within three regions of the glacial aquifer system extent.

The 1951-80 mean annual recharge for the model domain according to the method developed by Wolock (2003b) is $4.6 \mathrm{in} / \mathrm{yr}$, whereas the 1980-2011 mean annual potential recharge for the glacial SWB model is 25 percent higher at $5.8 \mathrm{in} / \mathrm{yr}$. The differences between the two models are shown in figures 21 and 23. Because these two datasets cover different periods, the differences between the models could represent differences in the methodology, differences in climate, or some combination thereof. The overall positive shift between the glacial SWB model and the Wolock (2003b) method likely results from differing hydrograph separation techniques. The BFI hydrograph separation method was used for the Wolock recharge dataset, whereas the HYSEP local minimum method was used for the glacial SWB model. For all the verification and calibration basins in table 5, the HYSEP local minimum method was, on average, 27 percent higher than the BFI method.

The glacial SWB model predicted lower potential recharge than the Wolock (2003b) study in some areas (figs. 22, 23); for example, the glacial SWB model predicted lower recharge than the BFI method for 1980-2011 in calibration basins in northern Wisconsin and Michigan. This finding indicates that differences in potential recharge between the glacial SWB model and the Wolock (2003b) study in this area are not attributable solely to the differences in hydrograph separation methods (figs. 11, 12). Climatic differences between the two periods, 1951-80 and 1980-2011, were not evaluated in this report. Further evaluation of climatic differences could help to determine factors that contribute to observed differences.

The glacial SWB model simulated mean annual potential recharge rates that were, on average, about 21 percent higher than the Williston Basin SWB model (figs. 20, 21, 24)
(Aurand, 2013; Long and others, 2014). The 1981-2011 mean annual potential recharge for the Williston Basin SWB model was $0.42 \mathrm{in} / \mathrm{yr}$, whereas the 1981-2011 mean annual potential recharge for the glacial SWB model was $0.51 \mathrm{in} / \mathrm{yr}$ for the same model extent. The differences in mean annual potential recharge between the Williston Basin SWB model and the glacial SWB model are shown in figure 21. More specifically, 84 percent of the coincident model cells had mean annual potential recharge values within 0.5 in. of each other, and 97 percent of model cells had a difference of less than $1 \mathrm{in}$. At the basin scale, the mean annual potential recharge for USGS streamgage 05120500 (map number 1 on fig. 1) was $0.5 \mathrm{in} / \mathrm{yr}$ using the Williston Basin model and 0.6 in/yr using the glacial SWB model (note: the glacial SWB potential recharge rate number differs from table 5 because the spatial and temporal extents were constrained to those of the Williston SWB model). Recharge determined with the HYSEP local minimum base-flow method over this same period was $0.4 \mathrm{in} / \mathrm{yr}$.

The differences between the Williston Basin SWB and glacial SWB model outputs reflect differences in model input data and calibration methods. Both models used the Daymet dataset (Thornton and others, 2014) and the NLCD (Fry and others, 2011), but the models used different HSG data. Model cells with the largest differences generally were in the eastern part of the coincident model domains in North and South Dakota (fig. 24). The Williston Basin model used geologic datasets (for example, Fullerton and others, 2003) to assign HSGs to model cells, whereas STATSGO2 was used for the glacial SWB model. The geologic dataset classified sediments using a much deeper sediment profile based on depositional processes than the STATSGO2 dataset, which only describes materials in the upper $2 \mathrm{~m}$ of the sediment profile. 


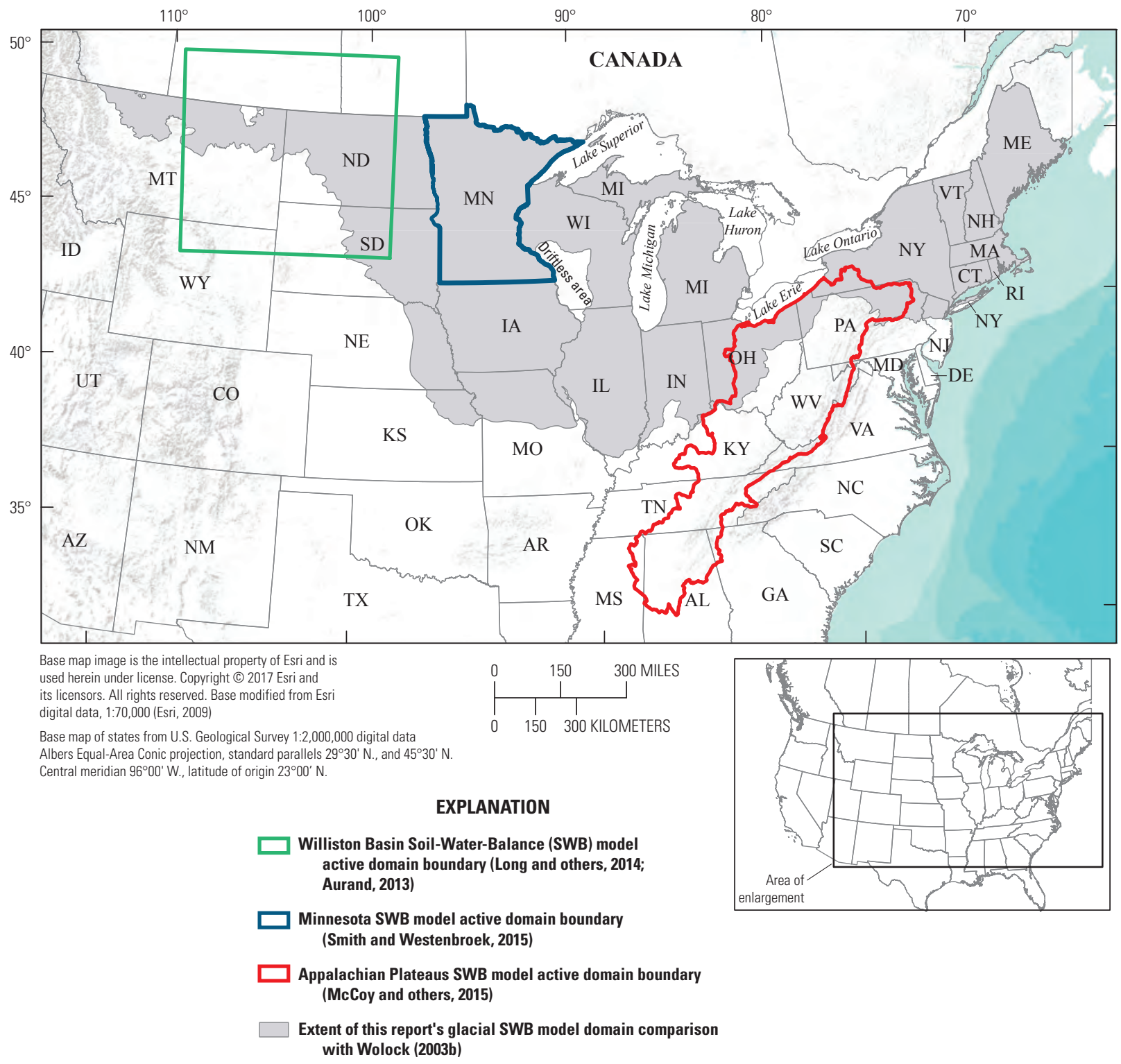

Figure 20. Boundaries of the glacial Soil-Water-Balance (SWB) model and boundaries of previously published recharge models (Wolock, 2003b; Long and others, 2014; Aurand, 2013; McCoy and others, 2015; Smith and Westenbroek, 2015).

The highest rates of recharge in the Willison Basin SWB model were in narrow bands of glaciofluvial deposits in the eastern part of the coincident model domain (fig. $24 B$, fig. 10 in Aurand, 2013). The highest rates of recharge in the glacial SWB model are more widely distributed in the eastern part of the coincident model domain (fig. 24A). The Williston Basin SWB model was calibrated manually by comparing model output to point estimates of recharge at specific wells calculated by the water-table fluctuation method and the chloride mass balance method (Aurand, 2013). In contrast, the glacial SWB model was calibrated to base flow using an automated process.
The glacial SWB model simulated mean annual potential recharge rates that were, on average, about 34 percent lower than the Minnesota SWB model (figs. 20, 21, 25) (Smith and Westenbroek, 2015). The 1996-2010 mean annual potential recharge for the Minnesota SWB model was $4.9 \mathrm{in} / \mathrm{yr}$, whereas the 1996-2010 mean annual potential recharge for the glacial SWB model was $3.3 \mathrm{in} / \mathrm{yr}$ for the same model extent. At the basin scale, the mean annual potential recharge for USGS streamgage 5317200 (map number 7 on fig. 1) was $4.1 \mathrm{in} / \mathrm{yr}$ using the Minnesota SWB model and $3.0 \mathrm{in} / \mathrm{yr}$ using the glacial SWB model (note: the glacial SWB potential recharge rate number differs from 


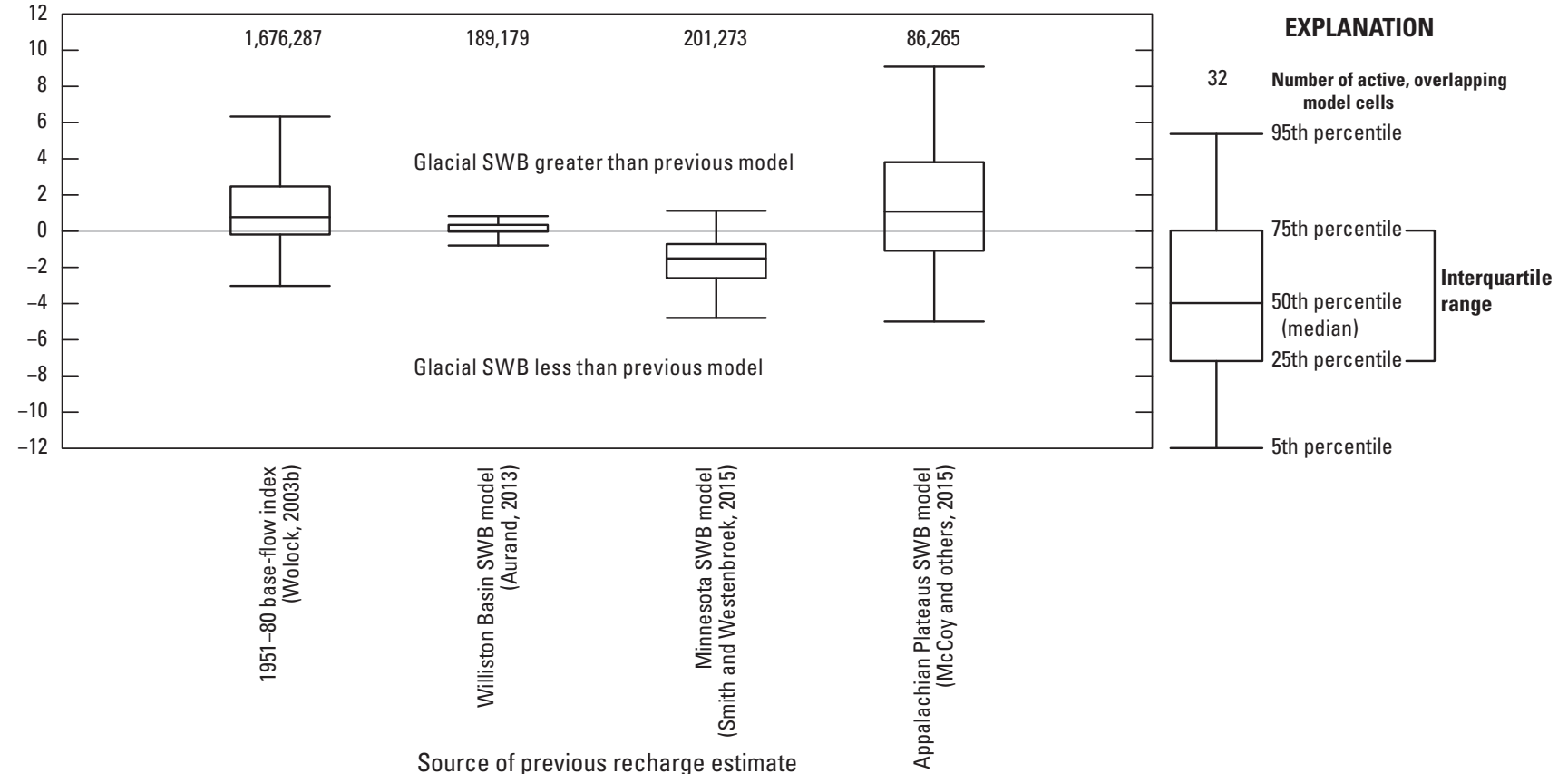

Figure 21. Cell-by-cell differences between mean annual potential recharge from the glacial Soil-Water-Balance (SWB) model and four previously published recharge estimates.

table 5 because the spatial and temporal extents were constrained to those of the Minnesota SWB model). Recharge determined with the HYSEP local minimum base-flow method over this same period was $4.3 \mathrm{in} / \mathrm{yr}$.

The overall spatial pattern in recharge is similar between the Minnesota SWB model and the glacial SWB model (fig. 25). Recharge generally increased from west to east, and the highest potential recharge was in the east-central and northeastern parts of the State. The Minnesota SWB model and the glacial SWB model used Daymet data and the NLCD. The Minnesota SWB model was calibrated by adjusting parameter values to minimize error between SWB potential recharge and estimates of base flow. The Minnesota SWB model used SSURGO data (rather than STATSGO2) to assign available water capacities and HSGs to model cells. Both models assumed that cells with dual HSGs were drained; for example, A/D soils were classified as A soils.

The combination of different hydrograph separation methods and differences in basin selection criteria likely led to the generally lower potential recharge estimates from the glacial SWB model compared to the Minnesota SWB model. The Minnesota SWB model was calibrated using an average of three hydrograph separation techniques: PART, HYSEP fixed-interval, and HYSEP sliding methods, whereas the glacial SWB model was calibrated to base flow from the HYSEP local minimum method. The HYSEP local minimum method produced base-flow estimates that were, on average, 16 percent lower than the average of the 3 methods used in the
Minnesota SWB model for the 39 calibration basins (table 5); furthermore, the basins used for the Minnesota SWB model calibration were not selected based on the same strict criteria for minimizing base-flow error as was used for the glacial SWB model. Only 6 of the 35 calibration basins were classified as GAGES II reference basins in the Minnesota SWB model, and several streams had regulated flows or were heavily tile drained (Falcone, 2011). Regulated flows and heavy tile drainage are known to cause overestimation of base flow from hydrograph separation (Schilling and Helmers, 2008; Sloto and Crouse, 1996).

Potential recharge to the Appalachian Plateaus during 1980-2011 was simulated using an SWB model by McCoy and others (2015) (fig. 20). The glacial SWB model simulated mean annual potential recharge rates that were, on average, about 17 percent higher (1.2 in/yr) than the Appalachian Plateaus SWB model within overlapping model extents. A side by side comparison of the mean annual potential recharge simulated with the glacial SWB model in this report and the mean annual potential recharge simulated with the Appalachian Plateaus SWB model is shown in figure 26. The Appalachian Plateaus model used SSURGO data to assign HSGs and available water capacity to model cells, whereas the glacial SWB model used STATSGO2 data for this task; furthermore, the Appalachian Plateaus SWB model assigned dual HSG soils $(\mathrm{A} / \mathrm{D}, \mathrm{B} / \mathrm{D}$, and $\mathrm{C} / \mathrm{D})$ to HSG D, whereas the glacial SWB model classified these soils to their drained condition, A, $\mathrm{B}$, or $\mathrm{C}$. 


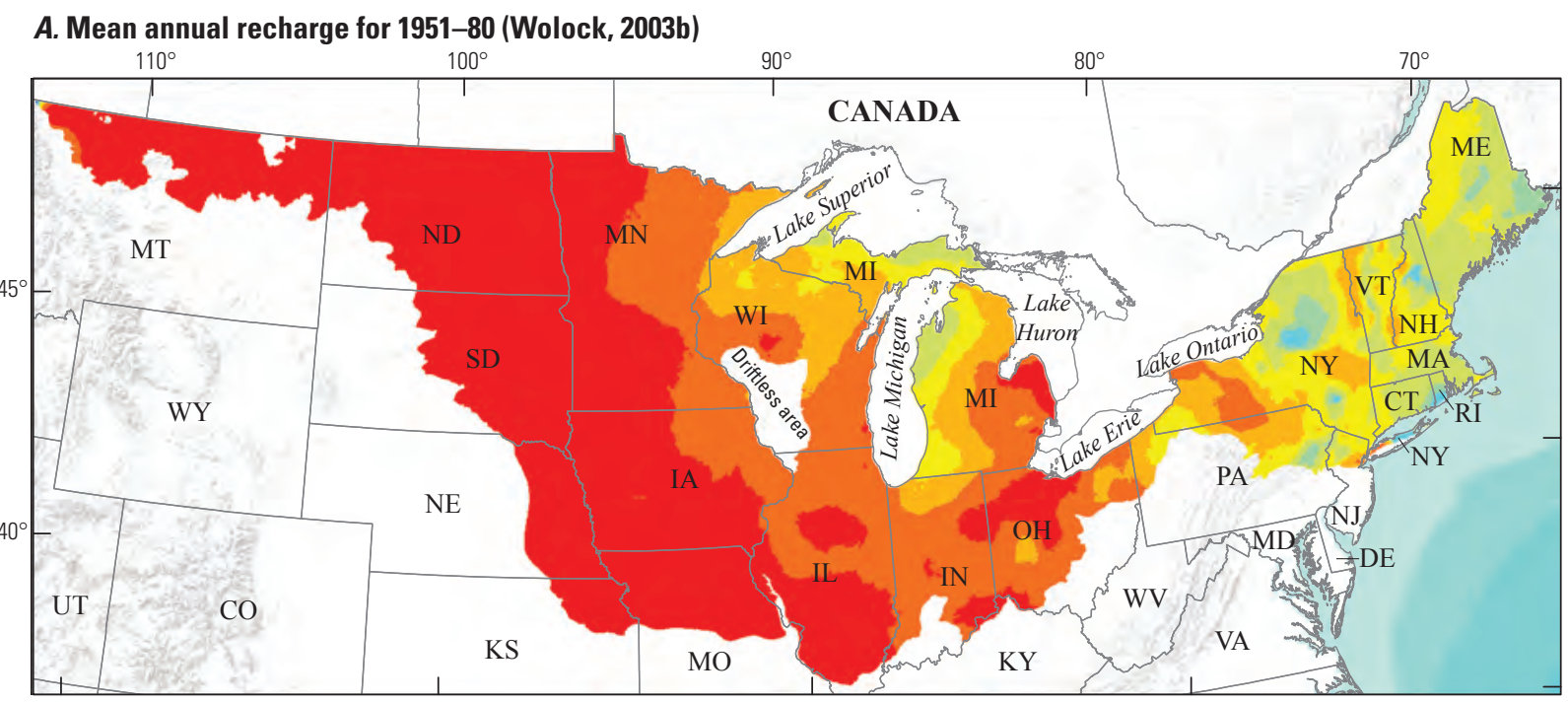

Base map image is the intellectual property of Esri and is used herein under license. Copyright $(C) 2017$ Esri and its licensors. All rights reserved. Base modified from Esri digital data, 1:70,000 (Esri, 2009)

Base map of states from U.S. Geological Survey 1:2,000,000 digital data Albers Equal-Area Conic projection, standard parallels $29^{\circ} 30^{\prime} \mathrm{N}$., and $45^{\circ} 30^{\prime} \mathrm{N}$. Central meridian $96^{\circ} 00^{\prime} \mathrm{W}$., latitude of origin $23^{\circ} 00^{\prime} \mathrm{N}$.

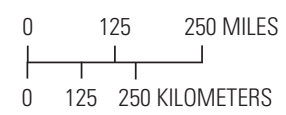

\begin{tabular}{lcc}
\hline & 1 & 1 \\
0 & 125 & 250 KILOMETERS
\end{tabular}

EXPLANATION

\begin{tabular}{|c|c|}
\hline 0 to 3.00 & 15.01 to 18.00 \\
\hline 3.01 to 6.00 & 18.01 to 21.00 \\
\hline 6.01 to 9.00 & 21.01 to 24.00 \\
\hline 9.01 to 12.00 & 24.01 to 27.00 \\
\hline 12.01 to 15.00 & 27.01 to 43.00 \\
\hline
\end{tabular}

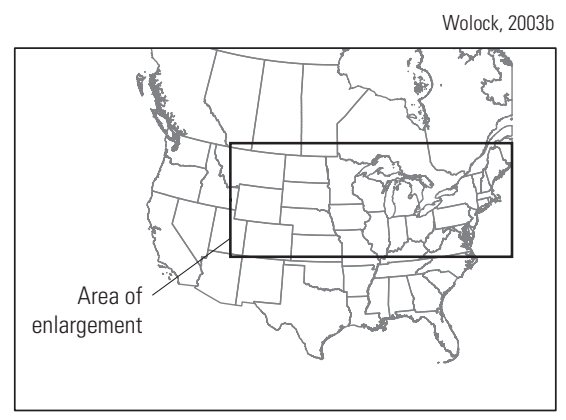

B. Mean annual potential recharge for 1980-2011 from the glacial Soil-Water-Balance model (fig. 14)

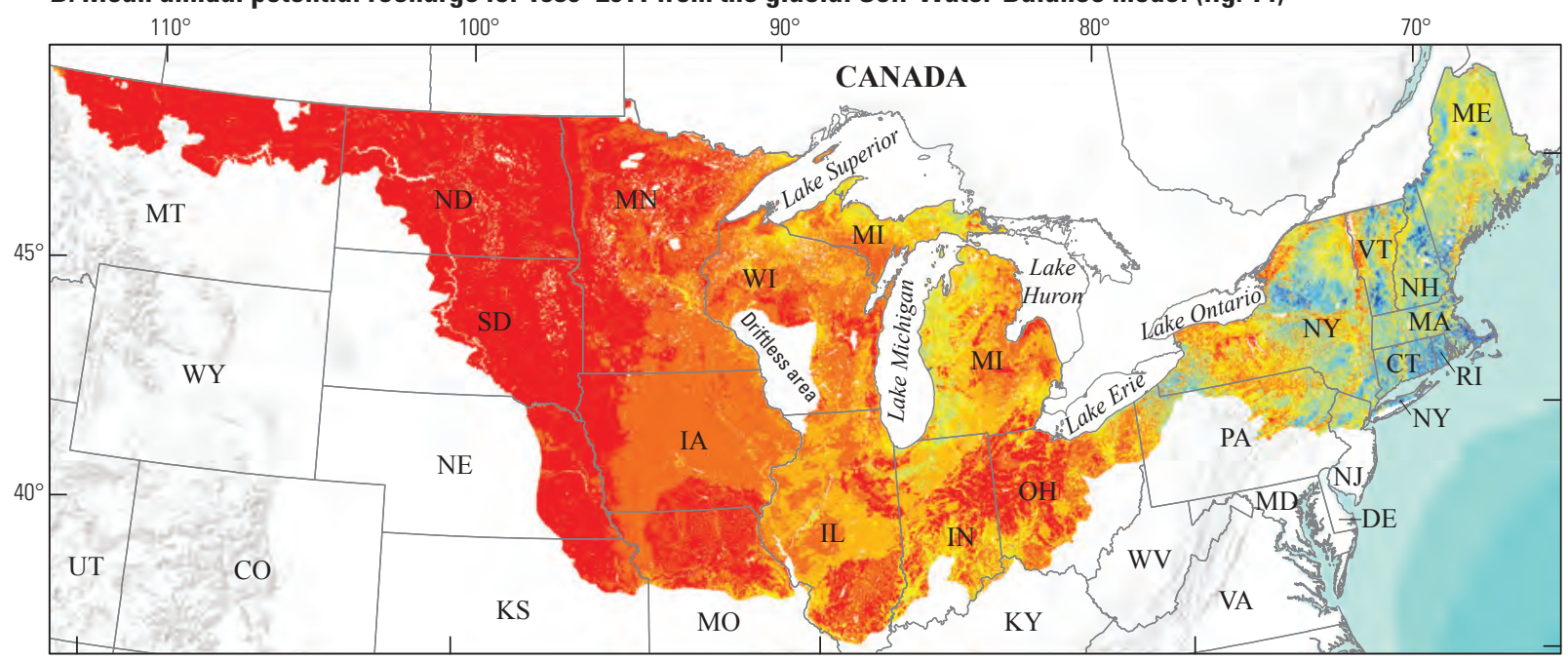

Base map image is the intellectual property of Esri and is used herein under license. Copyright (C) 2017 Esri and

its licensors. All rights reserved. Base modified from Esri digital data, 1:70,000 (Esri, 2009)

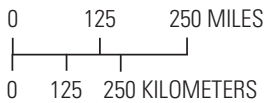

Base map of states from U.S. Geological Survey 1:2,000,000 digital data

Albers Equal-Area Conic projection, standard parallels $29^{\circ} 30^{\prime} \mathrm{N}$., and $45^{\circ} 30^{\prime} \mathrm{N}$.

Central meridian $96^{\circ} 00^{\prime} \mathrm{W}$., latitude of origin $23^{\circ} 00^{\prime} \mathrm{N}$.

Figure 22. The glacial aquifer system. $A$, mean annual recharge for 1951-80 according to Wolock (2003b); and $B$, the mean annual potential recharge for 1980-2011 simulated with the glacial Soil-Water-Balance (SWB) model. 


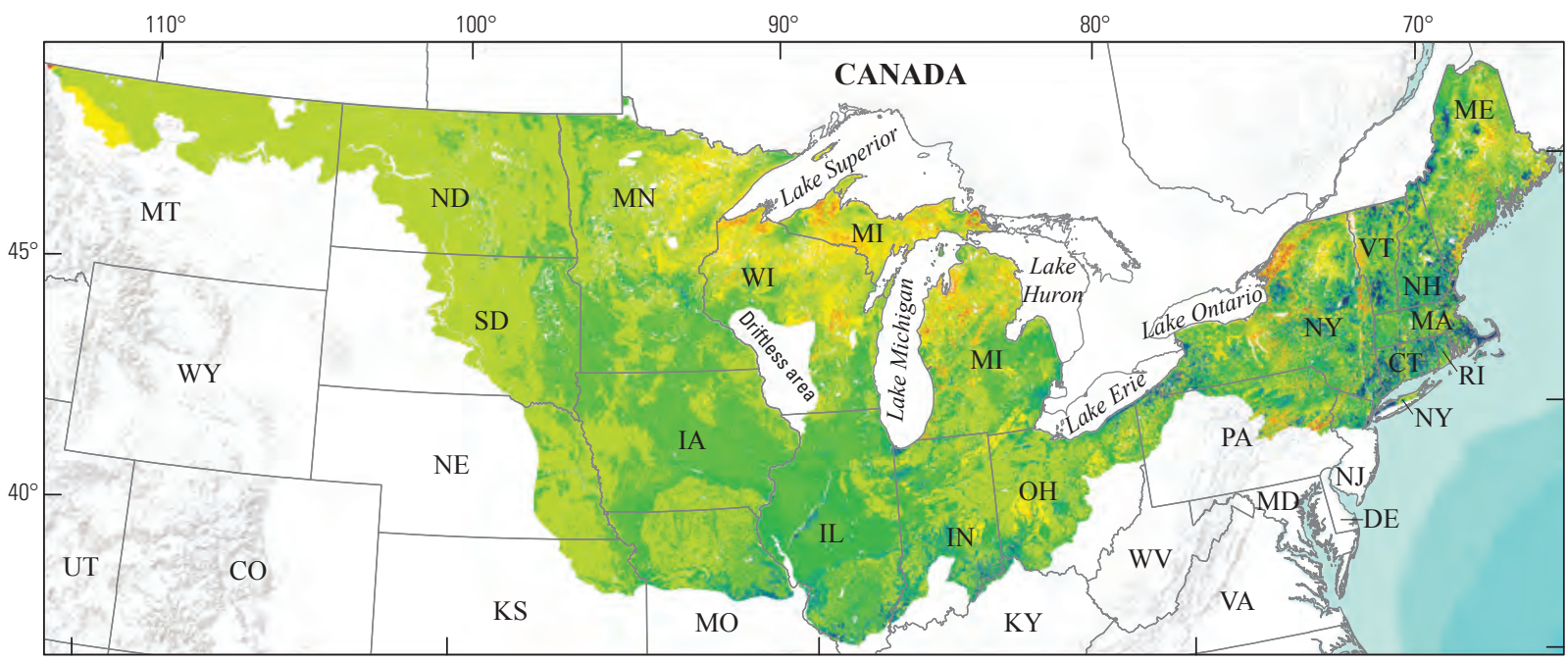

Base map image is the intellectual property of Esri and is used herein under license. Copyright (C) 2017 Esri and its licensors. All rights reserved. Base modified from Esri digital data, 1:70,000 (Esri, 2009)

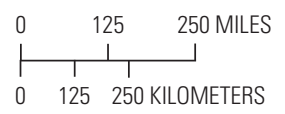

Base map of states from U.S. Geological Survey 1:2,000,000 digital data Albers Equal-Area Conic projection, standard parallels $29^{\circ} 30^{\prime} \mathrm{N}$., and $45^{\circ} 30^{\prime} \mathrm{N}$. Central meridian $96^{\circ} 00^{\prime} \mathrm{W}$., latitude of origin $23^{\circ} 00^{\prime} \mathrm{N}$.

\section{EXPLANATION}

Difference in mean annual potential recharge between 1951-80 (Wolock, 2003b) and 1980-2011 glacial Soil-Water-Balance model, in inches per year
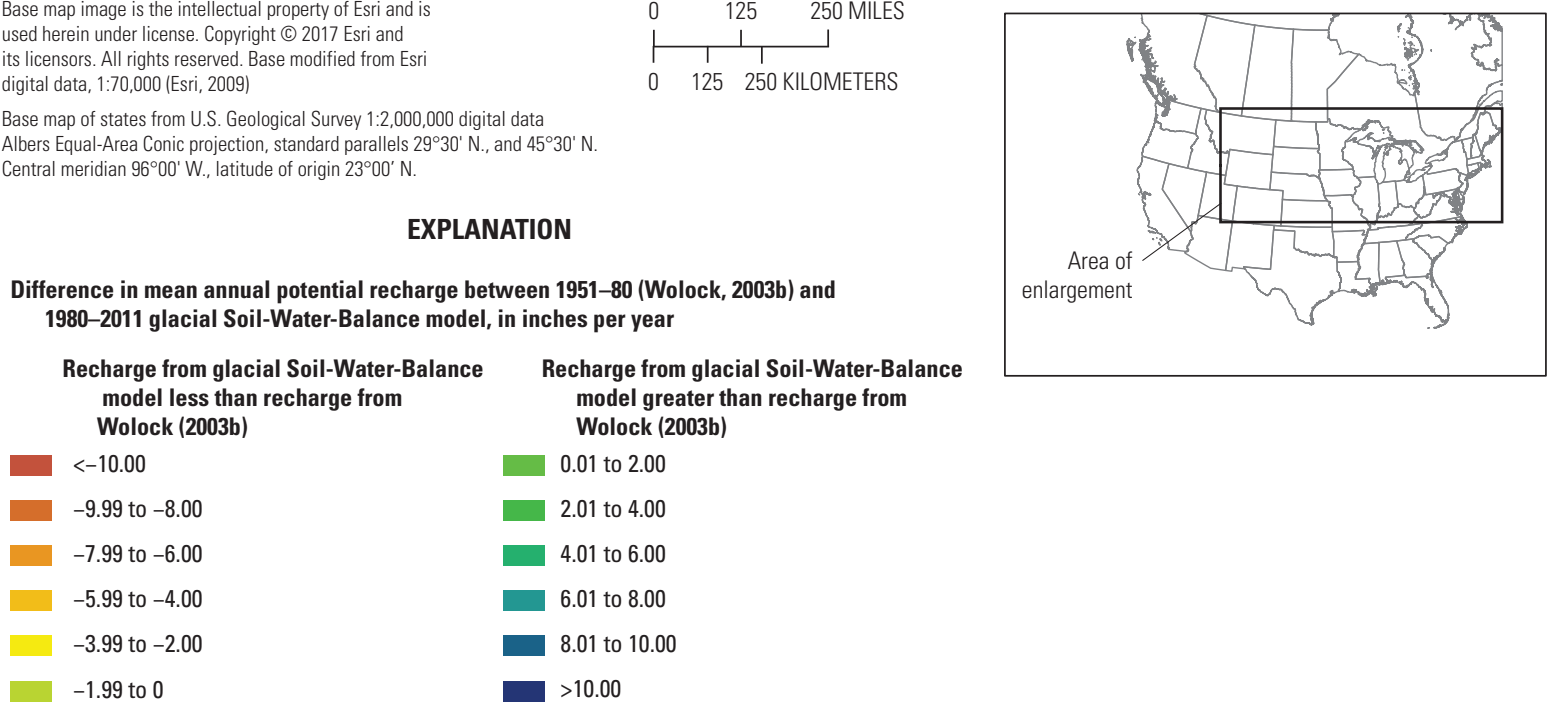
model less than recharge from Wolock (2003b)

Figure 23. The difference between the 1951-80 mean annual recharge determined by Wolock (2003b) and the 19802011 mean annual potential recharge simulated with the glacial Soil-Water-Balance model.

Regional patterns in figure 26 indicate that the glacial SWB model tends to simulate higher potential recharge in forested land cover and simulate lower potential recharge on agricultural crop and pasture lands compared to the Appalachian Plateaus SWB model (figs. 4, 26). The combination of HSG classification and parameterization for forest soils may explain why the glacial SWB model produced potential recharge estimates that are so much larger than potential recharge estimates produced by the Appalachian Plateaus SWB model in the forested areas of northwestern Pennsylvania and southwestern New York (fig. 26). In the glacial SWB model, this area was classified primarily as HSG C, whereas in the Appalachian Plateaus model, this region was classified primarily as HSG D (fig. 13 in McCoy and others, 2015).

The Appalachian Plateaus SWB model potential recharge estimates were at least 5 in below recharge estimated with the PART hydrograph separation technique for northwestern Pennsylvania and southwestern New York (McCoy and other, 2015), indicating that the Appalachian Plateaus SWB model underpredicted recharge there. At the basin scale in this area, the mean annual potential recharge for USGS streamgage 04213000 (map number 30, fig. 1) was $6.0 \mathrm{in} / \mathrm{yr}$ using the Appalachian Plateaus SWB model and $8.8 \mathrm{in} / \mathrm{yr}$ using the glacial SWB model. Recharge was determined to be $8.7 \mathrm{in} / \mathrm{yr}$ using the HYSEP local minimum baseflow method and $9.1 \mathrm{in} / \mathrm{yr}$ using the PART method (table 5).

In summary, model comparisons demonstrate that shifts in the overall distribution of potential recharge between models can be explained by methods used to generate base-flow calibration target datasets. The glacial SWB model potential recharge generally was lower than the Minnesota SWB model, likely because of differing basin selection criteria and hydrograph separation techniques. The glacial SWB model generally was higher than the Wolock (2003b) recharge estimates, again likely driven by the different hydrograph separation methods used for each model. Spatial patterns in potential recharge simulated by SWB models are strongly dependent on the data and assumptions used to assign model cells to HSGs. 
A. Glacial Soil-Water-Balance model

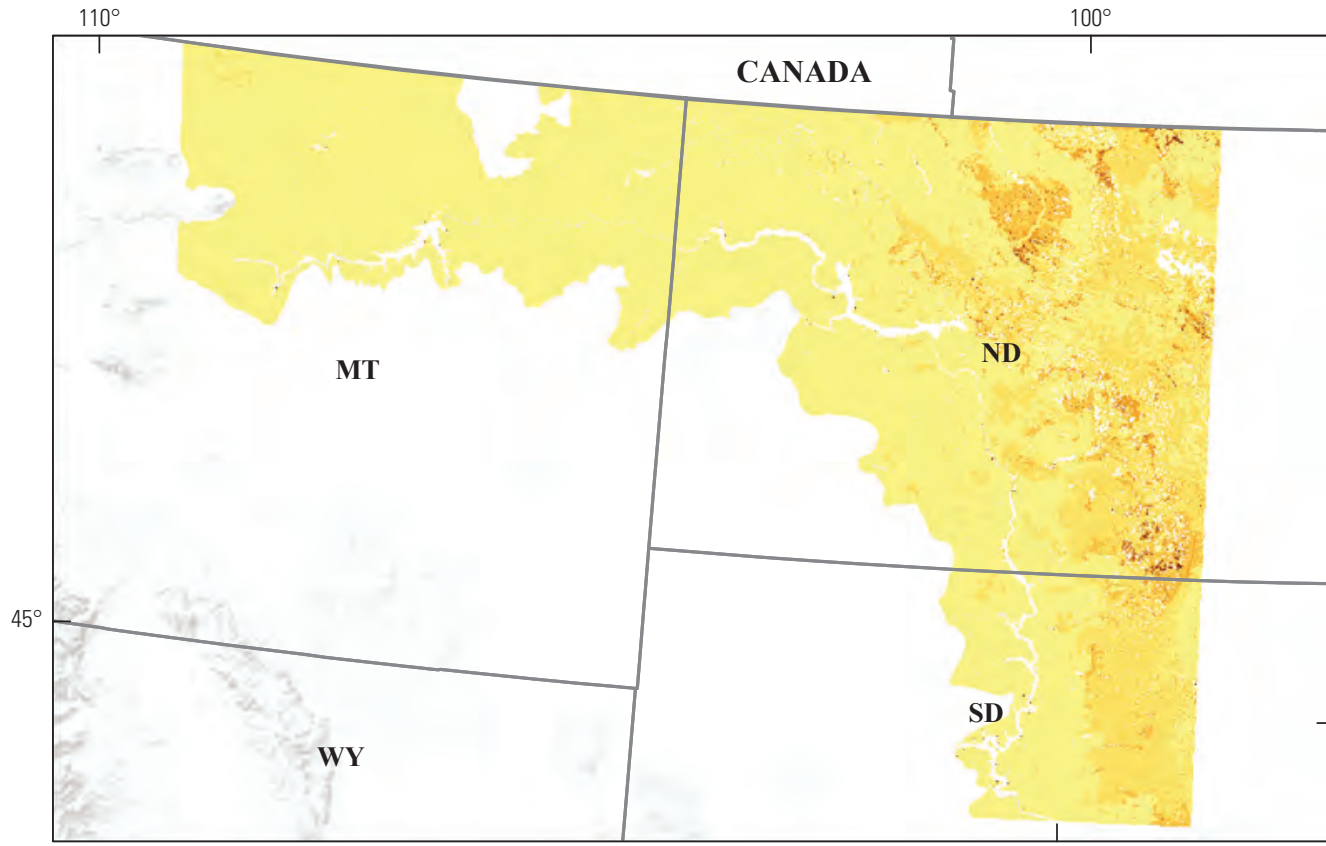

EXPLANATION

Mean annual potential recharge during 1981-2011, in inches per year

0 to 0.50

0.51 to 1.00

1.01 to 1.50

1.51 to 2.00

2.01 to 2.50

2.51 to 3.00

3.01 to a maximum of 10.14

\section{B. Williston Basin Soil-Water-Balance model (Aurand, 2013)}

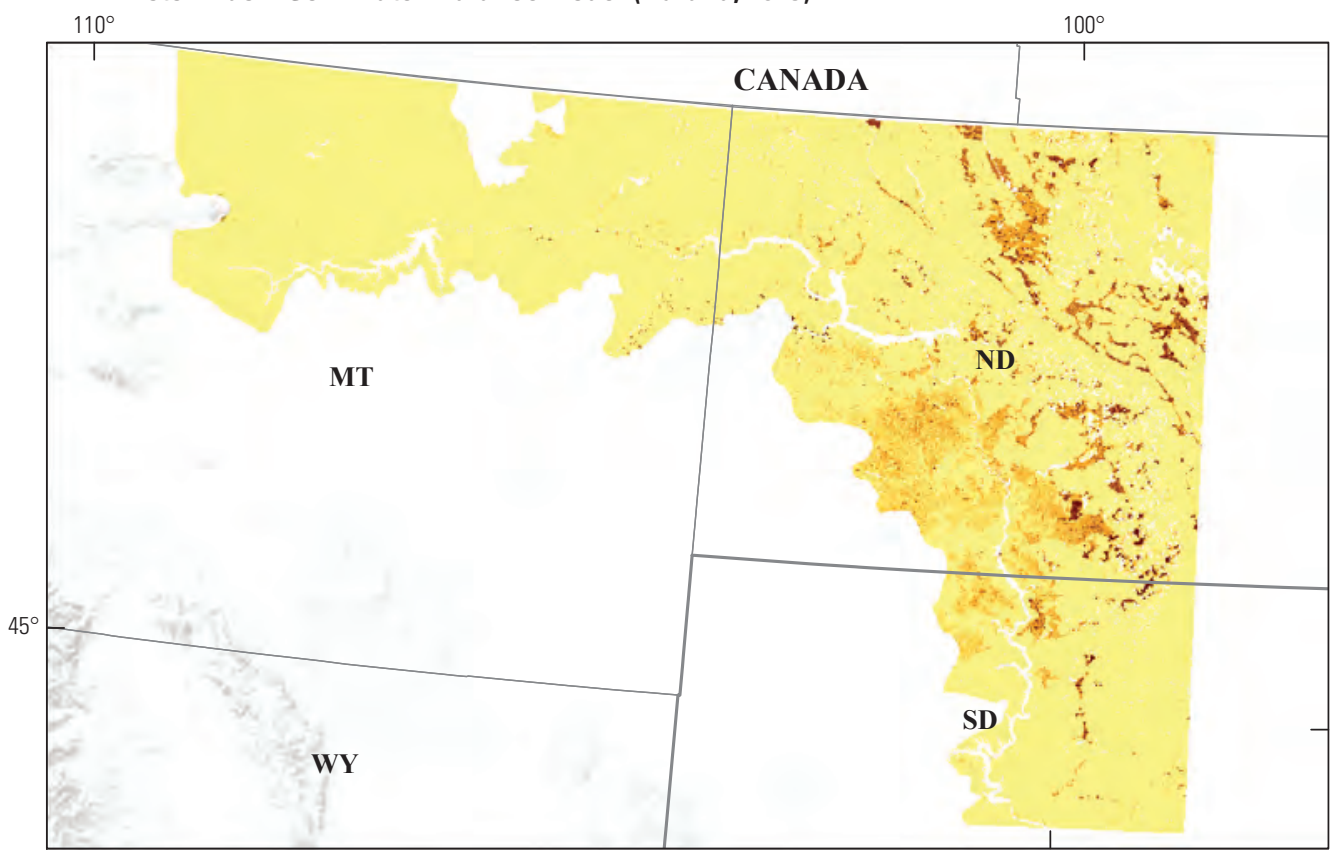

Base map image is the intellectual property of Esri and is used herein under license. Copyright (C) 2017 Esri and its licensors. All rights reserved. Base modified from Esri digital data, 1:70,000 (Esri, 2009)

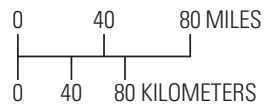

Base map of states from U.S. Geological Survey 1:2,000,000 digital data

Albers Equal-Area Conic projection, standard parallels $29^{\circ} 30^{\prime} \mathrm{N}$., and $45^{\circ} 30^{\prime} \mathrm{N}$.

Central meridian $96^{\circ} 00^{\prime} \mathrm{W}$. latitude of origin $23^{\circ} 00^{\prime} \mathrm{N}$.

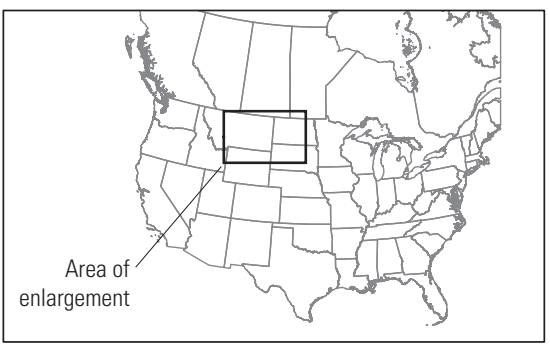

Figure 24. 1981-2011 mean annual potential recharge in the coincident model domains. $A$, of the glacial Soil-Water-Balance (SWB) model; and B, of the Williston Basin SWB model (Aurand, 2013). 


\section{A. Glacial Soil-Water-Balance model}

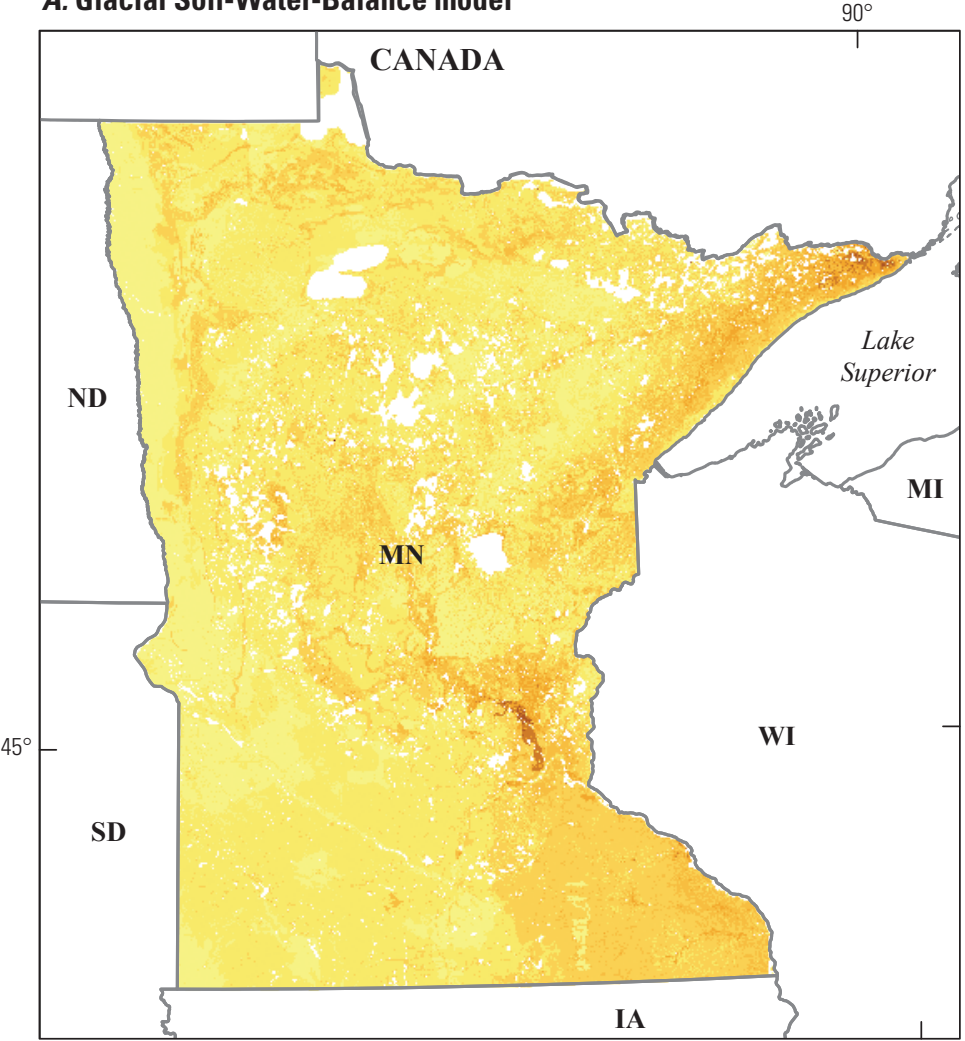

B. Minnesota Soil-Water-Balance model (Smith and Westenbroek, 2015)

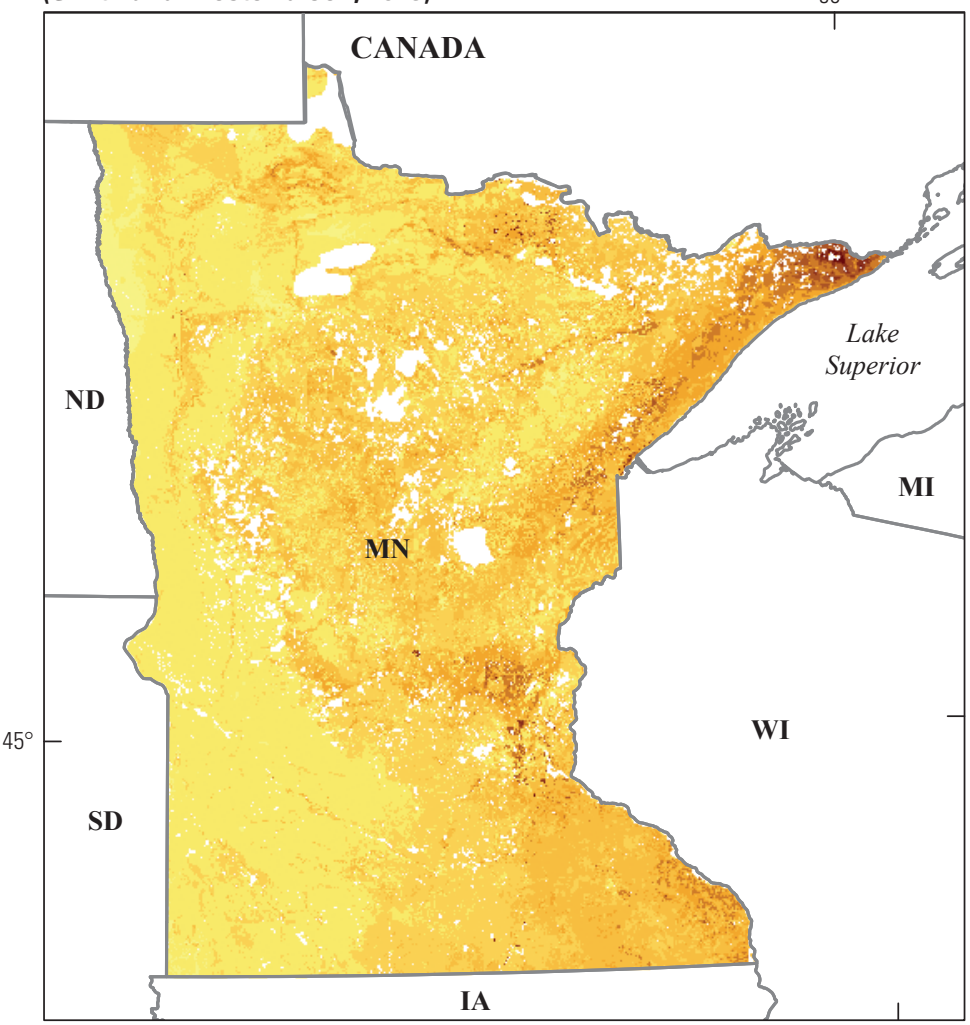

\section{EXPLANATION}

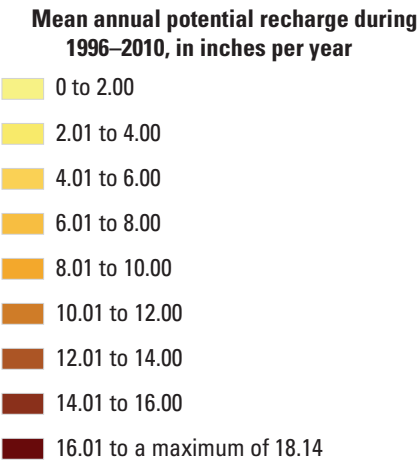

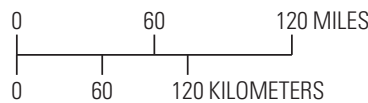

Base map image is the intellectual property of Esri and is used herein under license. Copyright (C) 2017 Esri and its licensors. All rights reserved. Base modified from Esri digital data, 1:70,000 (Esri, 2009)

Base map of states from U.S. Geological Survey 1:2,000,000 digital data Albers Equal-Area Conic projection, standard parallels $29^{\circ} 30^{\prime} \mathrm{N}$., and $45^{\circ} 30^{\prime} \mathrm{N}$. Central meridian $96^{\circ} 00^{\prime} \mathrm{W}$., latitude of origin $23^{\circ} 00^{\prime} \mathrm{N}$.

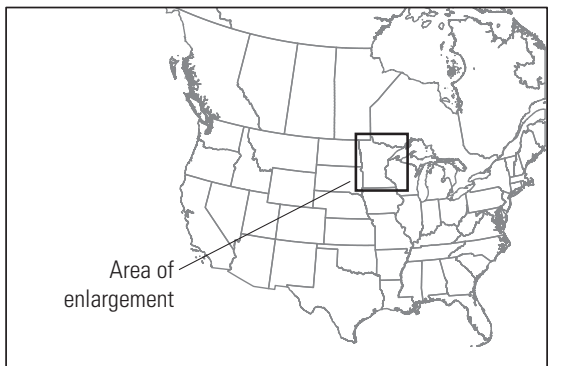

Figure 25. 1996-2010 mean annual potential recharge in the coincident model domains. $A$, of the glacial Soil-Water-Balance (SWB) model; and B, of the Minnesota SWB model (Smith and Westenbroek, 2015). 

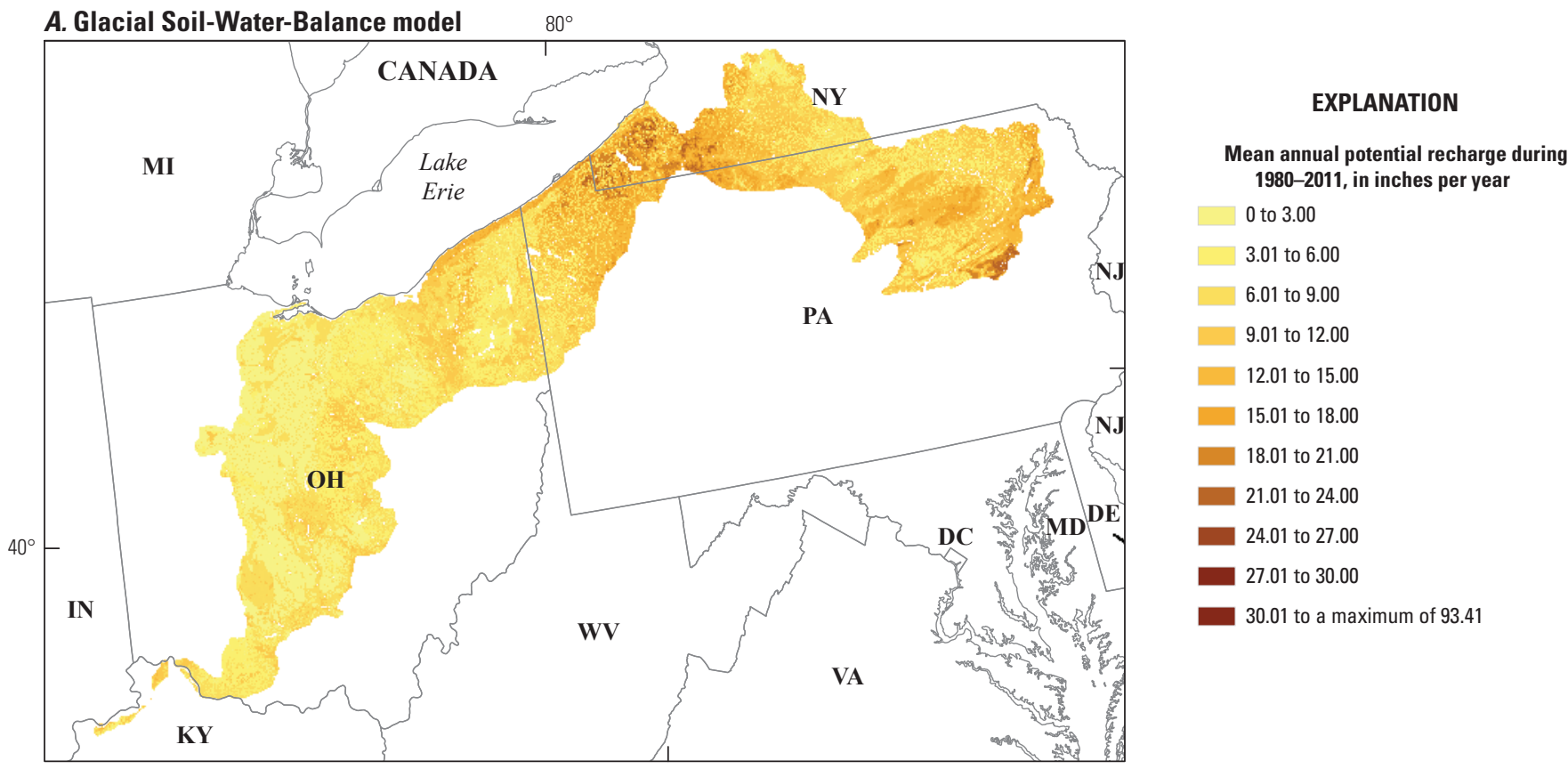

\section{B. Appalachian Plateaus Soil-Water-Balance model} (McCoy and others, 2015)

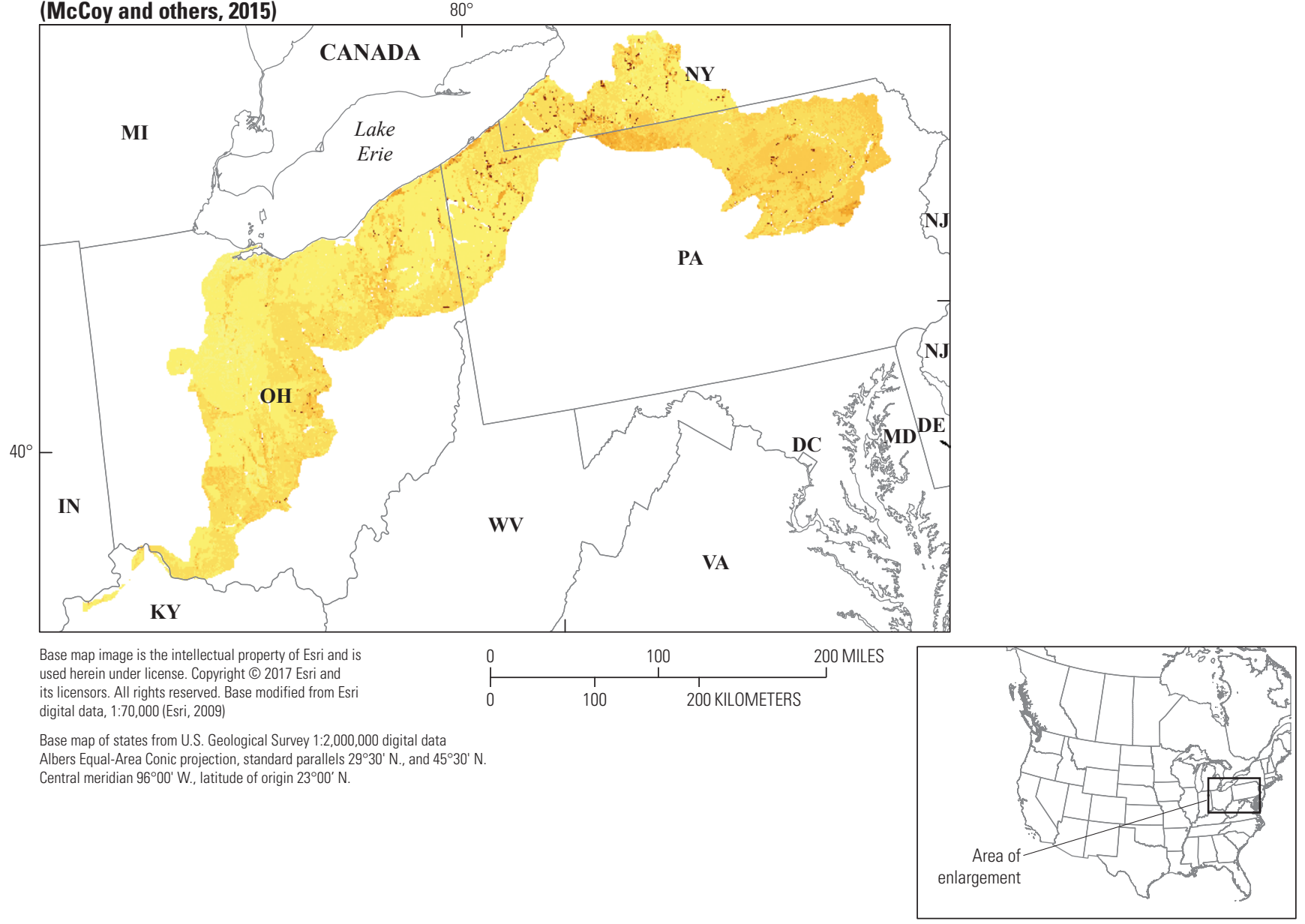

Figure 26. 1980-2011 mean annual potential recharge in the coincident model domains. $A$, of the glacial Soil-Water-Balance (SWB) model; and B, of the Appalachian Plateaus SWB model (McCoy and others, 2015). 


\section{Sensitivity Analysis}

Results of a sensitivity analysis of parameters used for the glacial SWB model are provided. Also included is a discussion of parameter sensitivities from previous SWB model applications.

\section{Glacial Soil-Water-Balance Model}

Model parameter sensitivities were evaluated by running the calibrated SWB model for all 39 calibration basins in the sensan utility of the PEST parameter-estimation software (Doherty, 2010). Of the 62 parameters that were adjusted during calibration, 55 were examined in the sensitivity analysis. The seven parameters that were excluded (cnmu_lu52, xstp mu2x, rzmu_lu2x, rzmu_lu52, rzmu_lu95, inmg_lu2x, and inma_lu52; table 8) were all multipliers that dealt with small areas of the model. Some of the 55 examined parameters were evaluated independently and others were grouped, resulting in 16 parameter groups that were increased by 10 percent and decreased by 10 percent. In rare cases, a 10 percent change would put a parameter out of bounds (for example, a curve number greater than 100). In these cases, the parameter was adjusted only to the maximum allowable value. The resulting change in the objective function (model error) for each parameter group perturbation was recorded. The percent change from the calibrated objective function is shown in table 11.

Negative values in table 11 indicate lower error compared to the calibrated model. In most cases, the reductions in error are minor; however, there is a large reduction in error $(-3.47 \%)$ when the root-zone depth parameters (RZB/RZC) are reduced by 10 percent (table 11). This observed reduction in error indicates that future automated calibration approaches tuned for mathematically underdetermined problems (such as SWB models) could improve on the current calibration; for example, singular value decomposition would address issues of parameter insensitivity and correlation (Doherty and Hunt, 2010).

The most sensitive parameters were those that dealt with the size of the soil-water reservoir (RZB/RZC) and the maximum rate at which water in the soil reservoir can become potential recharge on a daily basis (AMAXINF, BMAXINM, CMAXINM, and DMAXINM). The parameter AMAXINF affected every model cell (except for open water) because AMAXINF defined the maximum recharge rates for HSG A soils and was used for calculating the maximum recharge rates in all other HSGs. The parameter groups BMAXINM through EMAXINM (organic soils) only affected model cells within their respective HSG. In most cases, increases or decreases in maximum recharge rates resulted in substantial increases in model error, the notable exception being DMAXINM, where the model error was reduced when the maximum recharge rates on $\mathrm{D}$ soils were increased by 10 percent.

Potential recharge simulations also were sensitive to changes in the CND group of parameters. These parameters were used in calculations to define the runoff curve numbers for all model cells. The curve numbers partition water between runoff and infiltration; higher curve numbers increase runoff and decrease infiltration. The 10 percent decrease in curve numbers resulted in a substantial increase in model error, whereas a 10 percent increase in curve numbers caused a slight decrease in model error (table 11).

\section{Comparison of Parameter Sensitivities}

The recharge estimates from each of four SWB models (Lake Michigan Basin SWB model [Feinstein and others, 2010; Westenbroek and others, 2010], Minnesota SWB model [Smith and Westenbroek, 2015], High Plains aquifer SWB model [Stanton and others, 2011], and Appalachian Plateaus SWB model [McCoy and others, 2015]) had somewhat different parameter sensitivities. Sensitive parameters are those that, when changed, cause a large change in potential recharge estimates relative to the change in parameter value. One likely reason for recharge estimates having different parameter sensitivities is that the optimal parameter values for each model were in different parts of the parameter sensitivity spectrum. Though the calibration procedures for each of these three models were different and slightly different versions of the SWB model codes were used, parameter sensitivity results provide insight about the dependence of SWB model applications on certain types of information.

A parameter sensitivity analysis was completed for the Lake Michigan Basin SWB model in which curve number, root-zone depth, interception, and maximum recharge rate parameters from the lookup table and global parameters from the model control file were evaluated. The five most sensitive parameters were curve number controlling runoff volumes from the most abundant land-cover and HSG combinations. Of the 34 most sensitive parameters listed in the report, 15 were curve numbers, 8 were "global" parameters that affected recharge calculations in every single model cell, 5 were rootzone depths, 3 were maximum recharge rates, and 3 were plant-canopy interceptions. The sensitive global parameters controlled ET rates, growing season length, the CFGI, and rainfall (Westenbroek and others, 2010).

Smith and Westenbroek (2015) evaluated the sensitivity of curve numbers and root-zone depth parameters in the lookup table and climate data inputs including daily precipitation and daily maximum and minimum air temperatures. The Minnesota SWB model results were extremely sensitive to adjustments in precipitation and temperature input data. Of the curve number and root-zone depth parameters, the curve number for the dominant land-cover class (cultivated crops) was the single most sensitive parameter (Smith and Westenbroek, 2015).

In the Appalachian Plateaus SWB model, a sensitivity analysis was completed for curve number, root-zone depth, and canopy interception parameters on soils in HSGs B and C. In this SWB model application, simulated recharge was 
Table 11. Sensitivity of model error (objective function) to changes in parameters of the calibrated glacial Soil-Water-Balance model.

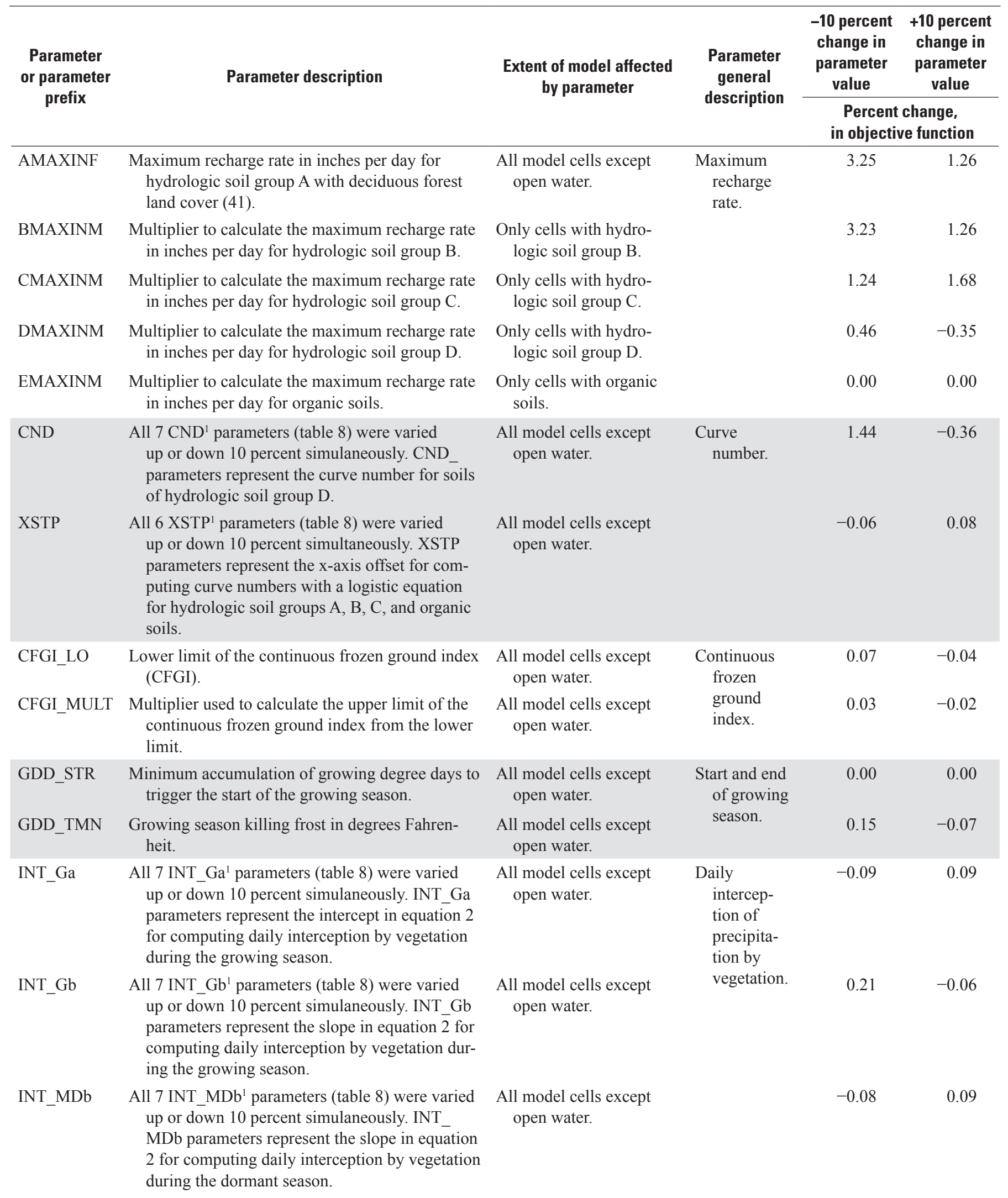


Table 11. Sensitivity of model error (objective function) to changes in parameters of the calibrated glacial Soil-Water-Balance model.-Continued

\begin{tabular}{|c|c|c|c|c|c|}
\hline \multirow{2}{*}{$\begin{array}{c}\text { Parameter } \\
\text { or parameter } \\
\text { prefix }\end{array}$} & \multirow[t]{2}{*}{ Parameter description } & \multirow[t]{2}{*}{$\begin{array}{l}\text { Extent of model affected } \\
\text { by parameter }\end{array}$} & \multirow{2}{*}{$\begin{array}{c}\text { Parameter } \\
\text { general } \\
\text { description }\end{array}$} & $\begin{array}{l}-10 \text { percent } \\
\text { change in } \\
\text { parameter } \\
\text { value }\end{array}$ & $\begin{array}{c}+10 \text { percent } \\
\text { change in } \\
\text { parameter } \\
\text { value }\end{array}$ \\
\hline & & & & \multicolumn{2}{|c|}{$\begin{array}{c}\text { Percent change, } \\
\text { in objective function }\end{array}$} \\
\hline RSLP & $\begin{array}{l}\text { All } 6 \text { RSLP }^{1} \text { parameters (table } 8 \text { ) were varied up } \\
\text { or down } 10 \text { percent simultaneously. RSLP pa- } \\
\text { rameters represent the slope in slope coefficient } \\
\text { for computing root-zone depths in hydrologic } \\
\text { soil groups A, B, C, D, and organic soils. }\end{array}$ & $\begin{array}{l}\text { All model cells except } \\
\text { open water, hydrologic } \\
\text { soil group B soils in } \\
\text { land-cover classes } 21 \text {, } \\
22,23,24,31,52,71, \\
81,90, \text { and } 95, \text { and hy- } \\
\text { drologic group C soils } \\
\text { in land-cover classes } \\
41,42,43,81 \text {, and } 82^{1} \text {. }\end{array}$ & $\begin{array}{l}\text { Root-zone } \\
\text { depths. }\end{array}$ & -0.11 & 0.10 \\
\hline
\end{tabular}

${ }^{1}$ Land-cover classes defined in tables 1, 2, and 3.

insensitive to changes in curve number parameters and more sensitive to changes in root-zone depth and plant-canopy interception parameters. Global parameters and maximum daily recharge values were not evaluated in this SWB model application (McCoy and others, 2015).

Stanton and others (2011) used an SWB model linked to a groundwater-flow model to estimate recharge to the High Plains aquifer; a sensitivity analysis for curve number parameters, root-zone depth parameters, and precipitation input was not completed. In this case, simulated recharge was most sensitive to changes in precipitation input, somewhat less sensitive to changes in root-zone depth, and insensitive to changes in curve number (Stanton and others, 2011).

Simulated recharge rates from three previous SWB models were evaluated for sensitivity to climatological input data or parameters that modified the input data (Westenbroek and others, 2010; Stanton and others, 2011; Smith and Westenbroek, 2015). Simulated recharge rates in all three cases were very sensitive to changes in input data, illustrating the importance of using reliable climatological data for any SWB model. The Daymet data (Thornton and others, 2014) used for the glacial SWB model is just one interpolation of climatic data that is easy to use with the SWB model. Local precipitation records may differ substantially from the Daymet data, especially if the area of interest is not near a precipitation gage used in the Daymet algorithms.

Simulated recharge rates from four previous SWB models were evaluated for sensitivity to curve number parameters and root-zone depth parameters (Westenbroek and others, 2010;
Stanton and others, 2011; McCoy and others, 2015; Smith and Westenbroek, 2015). The relative sensitivity of simulated recharge to curve number parameters and root-zone depth parameters is mixed among the four SWB models, which means that separate model applications depend differentially on different types of parameters. In the Lake Michigan SWB model, potential recharge was more sensitive to curve number parameters than to root-zone depth parameters (Westenbroek and others, 2010). In the High Plains aquifer SWB model and the Appalachian Plateaus SWB model, potential recharge was more sensitive to root-zone depths than curve numbers (Stanton and others, 2011; McCoy and others, 2015). In the Minnesota SWB model, potential recharge was nearly equally sensitive to curve number and root-zone depth parameters (Smith and Westenbroek, 2015), though the single most sensitive parameter was a curve number.

The increased sensitivity of potential recharge to changes in root-zone depth compared to changes in curve number observed for the glacial SWB model was more similar to observed responses for the Appalachian Plateaus and High Plains aquifer SWB models. Most previous sensitivity analyses did not consider maximum recharge rates; results from the glacial SWB model indicate that this parameter set also is important to evaluate. The comprehensive evaluation of parameters in the glacial SWB model also indicates that model results were not particularly sensitive to changes in global parameters that affect the length of the growing season nor to parameters controlling interception by vegetation. 


\section{Summary}

An understanding of the spatial and temporal extent of groundwater recharge is critical for many types of hydrologic assessments involving water quality, contaminant transport, ecosystem health, and sustainable use of groundwater. This report documents a Soil-Water-Balance (SWB) model used to simulate potential groundwater recharge to the glacial aquifer system. The glacial SWB model uses high resolution meteorological, land-cover, and soil hydrology datasets that are nationally consistent and publicly available, including Daymet meteorological data, the 2001, 2006, and 2011 National Land Cover Databases and STATSGO2 soils data as primary data inputs.

The SWB model was calibrated and used to simulate annual potential groundwater recharge rates for calendar years 1980-2011 using at a 1-kilometer resolution for the glacial aquifer system east of the Rocky Mountains. The SWB model computed daily potential groundwater recharge as precipitation in excess of interception, runoff, evapotranspiration, and soil-water storage capacity. Daily potential recharge values within each year of the simulation were summed to produce annual potential recharge rates. Potential recharge as described in this report is water that infiltrates vertically below the plant rooting zone and is assumed to reach the water table.

The glacial SWB model used parameters grouped by land-cover class, hydrologic soil group, or both in a lookup table for calculating the various water balance components. Parameter values for interception, runoff curve numbers, maximum recharge rates, and root-zone depths in the lookup table were adjusted during calibration. The SWB model calibration assumed that the area contributing to groundwater discharge equaled the surface watershed and was calibrated to stream base flows from 39 watersheds throughout the model domain that had hydrologic conditions appropriate for hydrograph separation. The calibration basins were minimally disturbed "reference" watersheds with high-quality, continuous streamflow records that spanned most or all of 1980-2011. Base flows were calculated from daily streamflow records with the HYSEP local minimum hydrograph separation method. Three base-flow data aggregations were used for model calibration: annual total base flow for each year of complete flow data, annual total base-flow duration deciles ( 10 deciles per basin, 10 percent through 100 percent), and the mean of all annual total base flows (mean annual) during 1980-2011. The glacial SWB model was verified with 38 basins that met the criteria for being a calibration basin.

The calibrated glacial SWB model adequately reproduced the observed recharge for the calibration and verification basins. The glacial SWB model reproduced the mean annual base-flow calibration targets well; the Nash-Sutcliffe efficiency (NSE) was 0.94 and the root mean squared error (RMSE) was 1.28 inches per year (in/yr). The calibrated model also simulated mean annual potential recharge rates that agreed well with mean annual base-flow in 38 verification basins; the NSE was 0.87 and the RMSE was $2.14 \mathrm{in} / \mathrm{yr}$. Most statistical measures applied for model evaluation indicated acceptable results. Some parts of the model domain had lower error rates than others. Generally, deviations between simulated and observed recharge were largest in the upper Midwest. Model evaluation statistics indicate that the model most accurately simulated the mean annual recharge. Variability in recharge derived from hydrograph separation methods differs among the calibration basins.

The glacial SWB model provides insight into the spatial and temporal variability in potential recharge across the glacial aquifer system. About 20 percent of the active model area had an average potential recharge rate of less than $1 \mathrm{in} / \mathrm{yr}$. A substantial part of the recharge water (39 percent) entering the glacial aquifer system travels through developed (urbanized) and agricultural landscapes, which are known to cause waterquality impairments. Approximately 46 percent of the potential recharge in the active model domain was in forested areas, and about 30 percent of the potential recharge was in agricultural areas. In North Dakota, mean precipitation generally is less than $20 \mathrm{in} / \mathrm{yr}$ (fig. 3), and potential recharge generally is less than 4 percent of precipitation. Conversely, in Maine, mean precipitation generally is above $40 \mathrm{in} / \mathrm{yr}$, and potential recharge generally is at least 18 percent of precipitation. Regional climatic events such as the 1988 to 1989 drought are apparent in the potential recharge time series. Annual potential recharge rates in all three regions of the glacial aquifer system generally increased between 2001 and 2011.

A comparison of the potential recharge from the glacial SWB model to previous broad-scale recharge estimates reveals several important considerations for future SWB modeling applications. Shifts in the overall distribution of potential recharge between separate models can be explained by methods used to generate base-flow calibration target datasets. Spatial patterns in potential recharge simulated by SWB models are strongly dependent on the data and assumptions used to assign model cells to hydrologic soil groups.

A sensitivity analysis indicated that the most sensitive parameters for the glacial SWB model dealt with the size of the soil-water reservoir and the maximum rate at which water in the soil reservoir can become potential recharge on a daily basis. Curve number parameters, which partition water between runoff and infiltration, also were sensitive. The comprehensive evaluation of parameters in the glacial SWB model indicated that model results were not particularly sensitive to changes in global parameters that affect the length of the growing season or to parameters controlling interception by vegetation. A review of several SWB models used to estimate groundwater recharge (and not surface runoff) revealed that model results have been most sensitive to input climatic data, followed by curve number and root-zone depth parameters. 


\section{Acknowledgments}

The authors thank the Groundwater Resources Program of the U.S. Geological Survey (USGS) for supporting this modeling effort. The authors also thank Erik Smith and Kurt McCoy of the USGS for their technical reviews of the manuscript, which greatly improved the quality of this report.

\section{References Cited}

Albert, D.A., 1994, Regional landscape ecosystems of Michigan, Minnesota, and Wisconsin-A working map and classification: General Technical Report NC-178, 4th revision, accessed December 2017 at https://www.nrs.fs.fed.us/pubs/ gtr/other/gtr-nc178/rlandscp.htm.

American Society of Civil Engineers, 1993, Criteria for evaluation of watershed models: Journal of Irrigation and Drainage Engineering, v. 119, no. 3, p. 429-442.

Anderson, M.P., 1989, Hydrogeologic facies models to delineate large-scale spatial trends in glacial and glaciofluvial sediments: Geological Society of America Bulletin, v. 101, no. 4, p. 501-511.

Anderson, M.P., Woessner, W.W., and Hunt, R.J., 2015, Applied groundwater modeling-Simulation of flow and advective transport ( $2 \mathrm{~d}$ ed.): Academic Press, Inc., 564 p.

Arnold, J.G., and Allen, P.M., 1999, Automated methods for estimating baseflow and ground water recharge from streamflow records: Journal of the American Water Resources Association, v. 35, no. 2, p. 411-424.

Arnold, J.G., Allen, P.M., Muttiah, R., and Bernhardt, G., 1995, Automated base flow separation and recession analysis techniques: Ground Water, v. 33, no. 6, p. 1010-1018.

Aurand, K., 2013, Groundwater recharge estimates for the Lower Tertiary and Upper Cretaceous aquifers in the Williston and Powder River structural basins: Rapid City, S. Dak., South Dakota School of Mines and Technology, M.S. thesis, accessed January 2015 at https://sd.water.usgs.gov/pubs/ theses/Aurand_Thesis.pdf.

Booth, D.B., Troost, K.G., Clague, J.J., and Waitt, R.B., 2003, The Cordilleran ice sheet: Developments in Quaternary Science, v. 1, no. C, p. 17-43.

Chapman, T., 1999, A comparison of algorithms for streamflow recession and baseflow separation: Hydrological Processes, v. 13, no. July 1998, p. 701-714.
Cronshey, R.G., McCuen, R.H., Miller, N., Rawls, W., Robbins, S., and Woodward, D., 1986, Urban hydrology for small watersheds_-TR-55 (2d ed.): Washington D.C., U.S. Department of Agriculture, Soil Conservation Service, Engineering Division, Technical Release 55, 164 p.

Doherty, J.E., 2010, PEST, model independent parameter estimation-User manual (5th ed., with slight additions): Brisbane, Australia, Watermark Numerical Computing, 336 p., accessed January 2015 at https://www.nrc.gov/docs/ ML0923/ML092360221.pdf.

Doherty, J.E., and Hunt, R.J., 2010, Approaches to highly parameterized inversion-A guide to using PEST for groundwater-model calibration: U.S. Geological Survey Scientific Investigations Report 2010-5169, 59 p., accessed June 1, 2018, at https://pubs.usgs.gov/sir/2010/5169/.

Donahue, R.L., Miller, R.W., and Shickluna, J.C., 1983, Soils-An introduction to soils and plant growth: Englewood Cliffs, New Jersey, Prentice Hall, 53 p.

Dorr, J.A., and Eschman, D.F., 1970, Geology of Michigan: Ann Arbor, Michigan, University of Michigan Press, 476 p.

Dripps, W.R., and Bradbury, K.R., 2007, A simple daily soilwater balance model for estimating the spatial and temporal distribution of ground-water recharge in temperate humid areas: Hydrogeology Journal, v. 15, no. 3, p. 433-444.

Eckhardt, K., 2005, How to construct recursive digital filters for baseflow separation: Hydrological Processes, v. 19, no. 2, p. 507-515.

Esri, 2009, World Terrain Base Map Service: Esri web page, accessed April 2015 at http:/goto.arcgisonline.com/maps/ World_Terrain_Base.

Esri, 2012, ArcGIS 10.1 SP1 software: Esri web page, accessed February 2015 at http://www.esri.com/.

Eyles, N., 1983, Glacial geology_A landsystems approach, in Eyles, N., ed., Glacial geology-An introduction for engineers and earth scientists: Oxford, Pergamon Press, p. 409.

Eyles, N., Clark, B.M., Kaye, B.G., Howard, K.W.F., and Eyles, C.H., 1985, The application of basin analysis techniques to glaciated terrains - An example from the Lake Ontario basin: Geoscience Canada, v. 12, no. 1, p. 22-32.

Falcone, J., 2011, GAGES-II-Geospatial attributes of gages for evaluating streamflow: U.S. Geological Survey web page, accessed September 2012 at https://water.usgs.gov/ lookup/getspatial?gagesII_Sept2011. 
Feinstein, D.T., Hunt, R.J., and Reeves, H.W., 2010, Regional groundwater-flow model of the Lake Michigan Basin in support of Great Lakes Basin water availability and use studies: U.S. Geological Survey Scientific Investigations Report 2010-5109, accessed August 2012 at https://pubs. usgs.gov/sir/2010/5109/.

Fry, J., Xian, G., Jin, S., Dewitz, J., Homer, C., Yang, L., Barnes, C., Herold, N., and Wickham, J., 2011, Completion of the 2006 national land cover database for the conterminous United States: Photogrammetric Engineering and Remote Sensing, v. 77, no. 9, p. 858-864.

Fullerton, D.S., Bush, C.A., and Pennell, J.N., 2003, Map of surficial deposits and materials in the Eastern and Central United States (east of $102^{\circ}$ west longitude): U.S. Geological Survey Geological Investigations Series I-2789, accessed August 2012 at https://pubs.usgs.gov/imap/i-2789/.

Gebert, W.A., and Krug, W.R, 1996, Streamflow trends in Wisconsin's driftless area: Journal of the American Water Resources Association, v. 32, no. 4, p. 733-744. [Also available at https://doi.org/10.1111/j.1752-1688.1996.tb03470.x.]

Gebert, W.A., Radloff, M.J., Considine, E.J., and Kennedy, J.L, 2007, Use of streamflow data to estimate base flow/ ground-water recharge for Wisconsin: Journal of the American Water Resources Association, v. 43, no. 1, p. 220 236. [Also available at https://doi.org/10.1111/j.17521688.2007.00018.x.]

Gebert, W.A., Walker, J.F., and Kennedy, J.L., 2011a, Estimating 1970-99 average annual recharge in Wisconsin using streamflow data: Reston, Va., U.S. Geological Survey OpenFile Report 2009-1210, 14 p. plus appendixes, accessed May 25, 2018, at https://pubs.er.usgs.gov/publication/ ofr20091210.

Gebert, W.A., Walker, J.F., and Hunt, R.J. 2011b, Groundwater recharge in Wisconsin-Annual estimates for 1970-99 using streamflow data: U.S. Geological Survey Fact Sheet 2009-3092, accessed May 25, 2018, at https://pubs.usgs. gov/fs/2009/3092/.

Gustard, A., Bullock, A., and Dixon, J.M., 1992, Low flow estimation in the United Kingdom: Institute of Hydrology Report Number 108, accessed November 2017 at http:// nora.nerc.ac.uk/6050/1/IH_108.pdf.

Hargreaves, G.H., and Samani, Z.A., 1985, Reference crop evapotranspiration from ambient air temperature: Applied Engineering in Agriculture, v. 1, no. 2, p. 96-99.

Healy, R.W., and Scanlon, B.R., 2010, Estimating groundwater recharge: Cambridge, Cambridge University Press, 256 p.
Helsel, D.R., and Hirsch, R.M., 2002, Statistical methods in water resources: Techniques of Water-Resources Investigations of the U.S. Geological Survey, Book 4, chapter A3, $522 \mathrm{p}$.

Hill, M.C., 1998, Methods and guidelines for effective model calibration: U.S. Geological Survey, Water-Resources Investigations Report no. 98-4005, 90 p.

Homer, C.G., Dewitz, J., Fry, J., Coan, M., Hossain, N., Larson, C., Herold, N., McKerrow, A., VanDriel, J.N., and Wickham, J., 2007, Completion of the 2001 National Land Cover Database for the counterminous United States: Photogrammetric Engineering and Remote Sensing, v. 73, no. 4, p. 337-341.

Homer, C.G., Dewitz, J.A., Yang, L., Jin, S., Danielson, P., Xian, G., Coulston, J., Herold, N.D., Wickham, J.D., and Megown, K., 2015, Completion of the 2011 National Land Cover Database for the conterminous United StatesRepresenting a decade of land cover change information: Photogrammetric Engineering and Remote Sensing, v. 81, no. 5 , p. 345-354.

Horton, R.E., 1919, Rainfall interception: Monthly Weather Review, v. 47, no. 9, p. 603-623.

Hunt, R.J., Prudic, D.E., Walker, J.F., and Anderson, M.P., 2008, Importance of unsaturated zone flow for simulating recharge in a humid climate: Ground Water, v. 46, no. 4, p. 551-560. [Also available at https://doi.org/10.1111/ j.1745-6584.2007.00427.x.]

Kahle, S.C., Morgan, D.S., Welch, W.B., Ely, D.M., Hinkle, S.R., Vaccaro, J.J., and Orzol, L.L., 2011, Hydrogeologic framework and hydrologic budget components of the Columbia Plateau regional aquifer system, Washington, Oregon, and Idaho: U.S. Geological Survey Scientific Investigations Report 2011-5124, 66 p.

Kanivetsky, R., 1979, Regional approach to estimating the ground-water resources of Minnesota: Minnesota Geological Survey Report of Investigations 22, 13 p., accessed January 2015 at http://purl.umn.edu/60457.

Legates, D.R., and McCabe, G.J., Jr., 1999, Evaluating the use of "goodness-of-fit" measures in hydrologic and hydroclimatic model validation: Water Resources Research, v. 35, no. 1, p. 233-241.

Lerner, D.N., Issar, A.S., and Simmers, I., 1990, Groundwater recharge- $\mathrm{A}$ guide to understanding and estimating natural recharge: International Contributions to Hydrogeology, v. 8, $345 \mathrm{p}$. 
Lins, H.F., 2012, USGS Hydro-Climatic Data Network 2009 (HCDN-2009): U.S. Geological Survey Fact Sheet 20123047, 4 p., accessed November 2014 at https://pubs.usgs. gov/fs/2012/3047/.

Long, A.J., Aurand, K.R., Bednar, J.M., Davis, K.W., Mckaskey, J.D.R.G., and Thamke, J.N., 2014, Conceptual model of the uppermost principal aquifer systems in the Williston and Powder River structural basins, United States and Canada: U.S. Geological Survey Scientific Investigations Report 2014-5055, 41 p., accessed April 2015 at https://doi. org/10.3133/sir20145055.

Lorenz, D.L., 2015,USGS-R/smwrStats-R functions to support statistical methods in water resources: rdrr.io web page, accessed February 2016 at https://rdrr.io/github/USGS-R/ smwrStats/.

Madramootoo, C.A., Johnston, W.R., Ayars, J.E., Evans, R.O., and Fausey, N.R., 2007, Agricultural drainage management, quality and disposal issues in North America: Irrigation and Drainage, v. 56, no. SUPPL. 1, p. S35-S45.

Marshall, S.J., Pollard, D., Hostetler, S., and Clark, P.U., 2003, Coupling ice-sheet and climate models for simulation of former ice sheets: Developments in Quaternary Science, v. 1, p. 105-126.

Masterson, J.P., Pope, J.P., Monti, Jack, Jr., Nardi, M.R., Finkelstein, J.S., and McCoy, K.J., 2013, Hydrogeology and hydrologic conditions of the Northern Atlantic Coastal Plain aquifer system from Long Island, New York, to North Carolina (ver. 1.1, September 2015): U.S. Geological Survey Scientific Investigations Report 2013-5133, 76 p., accessed January 2015 at https://doi.org/10.3133/sir20135133.

McCoy, K.J., Yager, R.M., Nelms, D.L., Ladd, D.E., Monti, Jack, Jr., and Kozar, M.D., 2015, Hydrologic budget and conditions of Permian, Pennsylvanian, and Mississippian aquifers in the Appalachian Plateaus physiographic province: U.S. Geological Survey Scientific Investigations Report 2015-5106, 77 p.

McMaster, G.S., and Wilhelm, W.W., 1997, Growing degreedays-One equation, two interpretations: Agricultural and Forest Meteorology, v. 87, no. 4, p. 291-300.

Metropolitan Council Environmental Services, 2013, Using a soil water balance (SWB) model to estimate recharge for version 3 of the Twin Cities metropolitan area groundwater model: St. Paul, Minn., 66 p., accessed March 2013 at https:/www.metrocouncil.org/METC/files/d2/d2996ed9646d-4cad-b4e2-7e60c6781c1a.pdf.

Mickelson, D.M., and Colgan, P.M., 2003, The southern Laurentide Ice Sheet: Developments in Quaternary Science, v. 1, no. C, p. 1-16.
Miller, J.A., 1999, Ground water atlas of the United StatesIntroduction and National summary: U.S. Geological Survey, HA-730 (and volumes within the HA-730 series), accessed January 2015 at https://pubs.usgs.gov/ha/ha730/ ch_a/index.html.

Molnau, M., and Bissell, V.C., 1983, A continuous frozen ground index for flood forecasting-Proceedings of the 51st Annual Meeting Western Snow Conference, April 19-21, 1983, Vancouver, Wash., Canadian Water Resources Assoc., p. 109-119.

Moriasi, D.N., Arnold, J.G., Van Liew, M.W., Bingner, R.L., Harmel, R.D., and Veith, T.L., 2007, Model evaluation guidelines for systematic quantification of accuracy in watershed simulations: Transactions of the ASABE, v. 50, no. 3, p. 885-900.

Nash, J.E., and Sutcliffe, J.V, 1970, River flow forecasting through conceptual models part I-A discussion of principles: Journal of Hydrology, v. 10, no. 3, p. 282-290.

Nathan, R.J., and McMahon, T.A., 1990, Evaluation of automated techniques for base flow and recession analyses: Water Resources Research, v. 26, no. 7, p. 1465-1473.

National Oceanic and Atmospheric Administration, 2002, State of the climate-Drought for December 2001: NCDC web page, accessed September 29, 2017, at https:/www. ncdc.noaa.gov/sotc/drought/200112.

Natural Resources Conservation Service, 2007, Hydrologic soil groups chap. 7 of National Engineering Handbook part 630 Hydrology: Natural Resources Conservation Service web page, accessed March 2015 at https://www.wcc.nrcs. usda.gov/ftpref/wntsc/H\&H/NEHhydrology/ch7.pdf.

Natural Resources Conservation Service, 2015, U.S. General Soil Map (STATSGO2): U.S. Department of Agriculture Soil Series Classification Database, accessed January 2015 at https://www.nrcs.usda.gov/wps/portal/nres/main/soils/ survey/.

Neff, B.P., Day, S.M., Piggott, A.R., and Fuller, L.M., 2005, Base flow in the Great Lakes Basin: U.S. Geological Survey Scientific Investigations Report 2005-5217, 23 p., accessed March 2013 at https:/pubs.usgs.gov/sir/2005/5217/pdf/ SIR2005-5217.pdf.

Neff, B.P., Piggott, A.R., and Sheets, R.A., 2006, Estimation of shallow ground-water recharge in the Great Lakes Basin: U.S. Geological Survey Scientific Investigations Report 2005-5284, 20 p., accessed March 2013 at https://pubs. usgs.gov/sir/2005/5284/.

R Development Core Team, 2014, R-A language and environment for statistical computing: Vienna, Austria, The R Foundation for Statistical Computing, 2673 p. 
Reeves, H.W., Bayless, E.R., Dudley, R.W., Feinstein, D.T., Fienen, M.N., Hoard, C.J., Hodgkins, G.A., Qi, S.L., Roth, J.L., and Trost, J.J., 2017, Generalized hydrogeologic framework and groundwater budget for a groundwater availability study for the glacial aquifer system of the United States: U.S. Geological Survey Scientific Investigations Report 2017-5015, 49 p., accessed December 2017 at https://doi.org/10.3133/sir20175015.

Rorabaugh, M.I., 1964, Estimating changes in bank storage and ground-water contribution to streamflow: International Association of Scientific Hydrology, no. 63, p. 432-441.

Rutledge, A.T., 1998, Computer programs for describing the recession of ground-water discharge and for estimating mean ground-water recharge and discharge from streamflow records-Update: U.S. Geological Survey Water-Resources Investigations Report 98-4148, 40 p., accessed January 2012 at https://pubs.usgs.gov/wri/wri984148/pdf/wri984148.pdf.

Saxton, K.E., and Rawls, W.J., 2006, Soil water characteristic estimates by texture and organic matter for hydrologic solutions: Soil Science Society of America Journal, v. 70, no. 5, p. $1569-1578$.

Scanlon, B.R., Healy, R.W., and Cook, P.G., 2002, Choosing appropriate techniques for quantifying groundwater recharge: Hydrogeology Journal, v. 10, no. 1, p. 18-39.

Schilling, K.E., and Helmers, M., 2008, Effects of subsurface drainage tiles on streamflow in Iowa agricultural watersheds-Exploratory hydrograph analysis: Hydrological Processes, v. 22, no. 23, p. 4497-4506.

Sloto, R.A., and Crouse, M.Y., 1996, HYSEP-A computer program for streamflow hydrograph separation and analysis: U.S. Geological Survey Water-Resources Investigations Report 96-4040, 46 p.

Smith, E.A., and Westenbroek, S.M., 2015, Potential groundwater recharge for the State of Minnesota using the SoilWater-Balance model, 1996-2010: U.S. Geological Survey Scientific Investigations Report 2015-5038, 85 p., accessed April 2015 at https://doi.org/10.3133/sir20155038.

Stanton, J.S., Qi, S.L., Ryter, D.W., Falk, S.E., Houston, N.A., Peterson, S.M., Westenbroek, S.M., and Christenson, S.C., 2011, Selected approaches to estimate water-budget components of the High Plains, 1940 through 1949 and 2000 through 2009: U.S. Geological Survey Scientific Investigations Report 2011-5183, 79 p., accessed August 2012 at https://pubs.usgs.gov/sir/2011/5183/.

Thornthwaite, C.R., and Mather, J.R., 1955, The water balance: Centerton, N.J., Drexel Institute of Technology-Laboratory of Climatology, Publications in Climatology, 104 p.
Thornthwaite, C.R., and Mather, J.R., 1957, Instructions and tables for computing potential evapotranspiration and the water balance: Drexel Institute of Technology-Laboratory of Climatology, Publications in Climatology, v. 10, no. 3, p. $185-311$.

Thornton, P.E., Running, S.W., and White, M.A., 1997, Generating surfaces of daily meteorological variables over large regions of complex terrain: Journal of Hydrology, v. 190, no. 3-4, p. 214-251.

Thornton, P.E., Thornton, M.M., Mayer, B.W., Wilhelmi, N., Wei, Y., Devarakonda, R., and Cook, R.B., 2014, DaymetDaily surface weather data on a 1-km grid for North America, version 2 data set: Oak Ridge National Laboratory Distributed Active Archive Center web page, accessed January 13, 2013, at https://daymet.ornl.gov.

Trenberth, K.E., and Branstator, G.W., 1992, Issues in establishing causes of the 1988 drought over North America: Journal of Climate, v. 5, no. 2, p. 159-172.

Trost, J.J., 2018, Soil-Water-Balance (SWB) model used to simulate potential groundwater recharge for the glacial aquifer system east of the Rocky Mountains, 1980-2011: U.S. Geological Survey Data Release, https://doi. org/10.5066/F7XW4HRJ.

Turnipseed, D.P., and Sauer, V.B., 2010, Discharge Measurements at Gaging Stations: U.S. Geological Survey Techniques and Methods book 3, chap. A8, 87 p.

U.S. Geological Survey, 2015, National Water Information System-Web Interface: accessed April 2015 at https:// waterdata.usgs.gov/nwis.

de Vries, J.J., and Simmers, I., 2002, Groundwater rechargeAn overview of processes and challenges: Hydrogeology Journal, v. 10, no. 1, p. 5-17.

Warner, K.L., and Arnold, T.L., 2006, Framework for regional synthesis of water-quality data for the glacial aquifer system in the United States: U.S. Geological Survey Scientific Investigations Report 2005-5223, 6 p.

Westenbroek, S.M., Doherty, J.E., Walker, J.F., Kelson, V.A., Hunt, R.J., and Cera, T.B., 2012, Approaches in highly parameterized inversion-TSPROC, a general time-series processor to assist in model calibration and result summarization: U.S. Geological Survey Techniques and Methods, no. $7-\mathrm{C} 7,112 \mathrm{p}$.

Westenbroek, S.M., Kelson, V.A., Dripps, W.R., Hunt, R.J., and Bradbury, K.R., 2010, SWB-A modified Thornthwaite-Mather Soil-Water- Balance code for estimating groundwater recharge: U.S. Geological Survey Techniques and Methods 6-A31, accessed January 2015 at https://pubs. usgs.gov/tm/tm6-a31/. 
Wieczorek, M.E., 2014, Area- and depth-weighted averages of selected SSURGO variables for the conterminous United States and District of Columbia: U.S. Geological Survey Data Series 866, accessed January 2015 at https://doi. org/10.3133/ds866.

Wolock, D.M., 2003a, Base-flow index grid for the conterminous United States: U.S. Geological Survey Open-File Report 2003-263, accessed April 30, 2015, at https://water. usgs.gov/lookup/getspatial?bfi48grd.

Wolock, D.M., 2003b, Estimated mean annual natural ground-water recharge in the conterminous United States: U.S. Geological Survey Open-File Report 2003-311, digital data set, accessed April 30, 2015, at https://water.usgs.gov/ lookup/getspatial?rech48grd.
Woodward, D.E., Hawkins, R.H., Jiang, R., Hjelmfelt, A.T., Jr., Van Mullem, J.A., and Quan, Q.D., 2003, Runoff curve number method-Examination of the initial abstraction ratio, in World Water and Environmental Resources Congress 2003, Proceedings: Philadelphia, 2003, American Society of Civil Engineers, p. 1-10.

Zambrano-Bigiarini, M., 2014, hydroGOF-Goodness-of-fit functions for comparison of simulated and observed hydrological time series: CRAN web page, accessed April 2015 at http://cran.r-project.org/package=hydroGOF.

Zucker, L.A., and Brown, L.C., 1998, Beneficial and adverse water quality impacts of drainage: Ohio State University Extension Bulletin 871-98, accessed December 2017 at http://irrigationtoolbox.com/ReferenceDocuments/BasicWaterManagement/f45_beneficial_and_adverse_effects_of agricultural_drainage.pdf. 



\section{Appendix. Model Archive}

The model archive is available at Trost (2018). The archive contains all files necessary to run the glacial Soil-Water-Balance (SWB) model described in this report. The model archive also contains model outputs, including the 1980-2011 annual recharge grids and the mean annual recharge grid. The binary output files also are available so users can extract recharge data at daily or monthly intervals with the SWBstats utility. 
For more information about this publication, contact Director, USGS Upper Midwest Water Science Center 2280 Woodale Drive

Mounds View, MN 55112

(763) 783-3100

For additional information visit https://mn.water.usgs.gov

Publishing support provided by the

Rolla Publishing Service Center 

